\title{
Guillermo Díaz-Plaja, director de l'Institut del Teatre durant el primer franquisme
}

\author{
ENRIC GALLÉN \\ Universitat Pompeu Fabra (Espanya) \\ orcid.org/0000-0003-1490-5102
}

Presentació: 30 set. 2015 | Acceptació: 15 oct. 2015 | Publicació: 15 des. 2015

Citació recomanada: GalléN, Enric. Guillermo Díaz-Plaja, director de l'Institut del Teatre durant el primer franquisme. Franquisme \& Transició. Revista d'Història i de Cultura 3 (2015): 41-119. doi: 10.7238/fit.voi3.2812.

Resum: Com a partícip del procés de substitució lingüística i literària encarrilat per les autoritats franquistes en el conjunt de les institucions i plataformes culturals catalanes, Guillermo Díaz-Plaja es va convertir a partir de 1939 en el director d'una entitat de preguerra, l'Escola Catalana d'Art Dramàtic, que, reconvertida en Institut del Teatre, va ser recuperada per la Diputació Provincial de Barcelona després de la seva vinculació a la Generalitat republicana. Des del primer moment, Díaz-Plaja va projectar la seva ambició i empremta més personals en la gestió del centre. Va aconseguir que l'antiga Escola creada per Adrià Gual es convertís en una Escola Superior d'Art Dramàtic, de característiques semblants a la Real Escuela Superior de Arte Dramático de Madrid. Com a contrapunt a aquest reconeixement professional de la seva gestió, Díaz-Plaja va mantenir, en canvi, una posició molt tímida en relació amb la restauració de la catalanitat original del centre. Tampoc el seu projecte més ambiciós, la creació d'un Teatro de la Ciudad, amb una important i directa

Aquest article s'inscriu en les activitats del TRILCAT, grup de recerca reconegut per l'AGAUR de la Generalitat de Catalunya, ref. 2014SGR-486. Un primer estat d'aquest text el vaig presentar al seminari La Política Cultural del Primer Franquisme a l’Ajuntament de Barcelona i la Diputació Provincial, organitzat per la Fundació Carles Pi i Sunyer a Barcelona, els dies 10 i 11 de juny de 2010. Vull agrair de manera especial a Olívia Gassol i Bellet que em facilités una part de la documentació relacionada amb l'Institut del Teatre, dipositada a l'Arxiu General de la Diputació de Barcelona (a partir d'ara AGDB); a Ana Díaz-Plaja Taboada la consulta de l'Arxiu Díaz-Plaja a la Reial Acadèmia de Bones Lletres de Barcelona (a partir d'ara RABLB), i a Guillem-Jordi Graells que en llegís l'original i en fes observacions que han millorat la versió definitiva. També vull agrair l'atenció i les facilitats donades pel personal del CDMAE de l'Institut del Teatre de Barcelona pel que fa a la consulta dels seus fons. 
implicació de l'Institut del Teatre, no es va acabar de materialitzar durant el primer franquisme.

Paraules clau: Guillermo Díaz-Plaja, Adrià Gual, Institut del Teatre, Escola Superior d'Art Dramàtic, teatre català, franquisme, Teatro de la Ciudad

\section{Guillermo Díaz-Plaja, director of the Institut del Teatre during the first Francoism}

Abstract: Guillermo Díaz-Plaja cooperated in the process of substitution of Catalan language and literature accomplished by Franco's regime in all Catalan cultural platforms and institutions. In that context, from 1939 Guillermo Díaz-Plaja became the headmaster of the Escola Catalana d'Art Dramàtic (Catalan School of Dramatic Arts), which was reconverted to the Institut del Teatre, recovered by the Diputació Provincial de Barcelona (Provincial Council of Barcelona) after being linked to the Catalan autonomous government during the Republic. From the beginning, Díaz-Plaja projected his most personal ambition in the management of this institution. He achieved that the ancient school, founded by Adrià Gual, was converted into the Escola Superior d'Art Dramàtic (School of high education in Dramatic Arts), a similar institution to the Real Escuela Superior de Arte Dramático (School of high education in Dramatic Arts) in Madrid. On the other side of this professional recognition to his management, Díaz-Plaja maintained a feeble position to restore the Catalan origin of the centre. At the same time, his most ambitious project, to create a «Teatro de la Ciudad» (Theatre of the City), with an important and direct implication of the Institut del Teatre, was neither materialised during the first years of Franco's regime.

Keywords: Guillermo Díaz-Plaja, Adrià Gual, Institut del Teatre, Escola Superior d’Art Dramàtic, Catalan drama, Franco's regime, Teatro de la Ciudad 


\section{Presentació}

Encarar-se a la trajectòria professional de Guillermo Díaz-Plaja significa fer-ho a una de les personalitats intellectuals més ambicioses i alhora productives de la cultura catalana del seu temps. ${ }^{1}$ Com en altres casos semblants, en la seva carrera es dóna un abans i un després del conflicte bèllic i el procés revolucionari viscut a Catalunya. Díaz-Plaja forma part del grup d'escriptors i intellectuals catalans que, poc després de l'ocupació franquista de la ciutat de Barcelona, va collaborar en el procés general d'espanyolització endegat sota la fèrula falangista en el conjunt de les institucions i plataformes culturals catalanes. ${ }^{2}$

Per tal de contextualitzar el rerefons de la gestió de Díaz-Plaja en la política cultural del primer franquisme, vull assenyalar algunes de les seves actuacions i aportacions al sistema cultural dels anys trenta com a membre de l'anomenada Generació de 1936, la que ell mateix va titllar posteriorment de «destruída» o «sacrificada».3 Efectivament, Díaz-Plaja va desplegar una activitat intensa en diferents àmbits i aspectes de la vida

1 Sobre el grup universitari a què pertany, és imprescindible la consulta de la tesi de Josep M. BALAGUer SANCho, Joan Teixidor, representant del «Grup Universitari». Poesia i Crítica (1931-1951) (tesi doctoral, Universitat Autònoma de Barcelona, 1993). Vegeu també Jordi AmAT, «Memoria(s) de la tertulia del Lyon d'Or», Ínsula 738 (juny 2008): 23-25. Sobre Díaz-Plaja en particular, vegeu Ana DíAzPlaja, Elvira Roca-Sastre \& Leonor Vela, ed., Bibliografia del Dr. Guillem Díaz-Plaja, Sèries Minor 12 (Barcelona: Reial Acadèmia de Bones Lletres, 2007); José Carlos MAINER, El ensayista bajo la tormenta: Guillermo Díaz-Plaja (1928-1941), La filología en el purgatorio. Los estudios literarios en torno a 1950 (Barcelona: Crítica, 2003), 17-38; Jordi AмAт, «Fer-se franquista», dins El llarg procés. Cultura i política a la Catalunya contemporània (1937-2014), L'Ull de Vidre 55 (Barcelona: Tusquets Editores, 2015), 72-82. Vegeu també Salvador PÁNIKER, «Guillermo Díaz-Plaja», dins Conversaciones en Madrid (Barcelona: Editorial Kairós, 1969), 205-215, i el web http://www.guillermodiazplaja.com/.

2 Entre altres, vegeu les següents aportacions: Francesc Vilanova, Una burgesia sense ànima. El

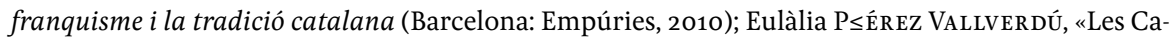
talunyes de Destino. Política de Unidad. Depuració, espanyolització i reinterpretació de la història i de la tradició cultural i literària catalanes» i Ramon PANYELLA, «L'espanyolització de la vida cultural catalana en la primera postguerra: La Fiesta de las Letras (1942-1953) de la Asociación de la Prensa de Barcelona», dins Olívia GASSOL Bellet, ed., Postguerra. Reinventant la tradició literària catalana (Lleida: Punctum, 2013), 85-111 i 153-177, respectivament.

3 Vegeu Memoria de una generación destruida (1930-1936), Colección Fiel Contraste 1 (Barcelona: Editora Delos-Aymà, 1966). 
cultural catalana dels trenta. Des del punt de vista acadèmic, un cop enllestits els estudis de llicenciatura i doctorat (1930-1931), ${ }^{4}$ va ser professor adjunt de la càtedra del Dr. Ángel Valbuena Prat a la Universitat Autònoma, on també va impartir un curs de cinema (1932); va dirigir la Secció d'Art Dramàtic del Conservatori del Liceu (1933 i 1934); 5 va ser professor del'Institut-Escola Pi i Margall (1933), i va guanyar la plaça de catedràtic de literatura espanyola a l'Institut Jaume Balmes (1935). Quant al conjunt de la seva obra intellectual (creació, recerca i divulgació), va contribuir-hi amb un total de trenta-una aportacions, que assenyalen el seu afany de projecció en la cultura hispànica amb una aposta personal per la difusió de les literatures catalana i espanyola. De les publicacions en llengua catalana, paga la pena remarcar-ne quatre llibres: Una cultura del cinema: introducció a una estètica del film (1930); Lavantguardisme a Catalunya i altres notes de crítica (1932); L'evolució del teatre (1934); Cartes de navegar (1935), basat en el creuer del grup universitari per la Mediterrània (1933); 6 un parell d'articles publicats a Estudis Universitaris Catalans (1933) i Revista de Catalunya (1934),7 i dos més a Quaderns de Poesia $(1935,1936) .{ }^{8}$ Quant a les manifestacions relacionades amb l'estudi sobre la literatura espanyola, cal destacar la Introducción al estudio del Romanticismo español, Premio Nacional de Literatura 1935, i l'edició i

4 Vegeu Jordi Rubió i Balaguer, «Guillem Díaz-Plaja», dins Mestres, companys i amics, Biblioteca Abat Oliba 101 (Barcelona: Publicacions de l'Abadia de Montserrat, 1991), 215-223, i el text del mateix Guillermo DíAz-PlajA, «Rubió i Balaguer», dins Sociología cultural del posfranquismo (Barcelona: Plaza \& Janés, 1979), 212-215.

5 «La nueva organización de los estudios de Arte Dramático en el Conservatorio del Liceo», La Vanguardia, 16 set. 1933, 5; «La vida cultural. Secció de Declamació del Conservatori del Liceu», La Veu de Catalunya, 16 set. 1933, 6 .

6 Vegeu Francisco Gracia \& Josep M. Fullola, El sueño de una generación. El crucero universitario por el Mediterráneo de 1933 (Barcelona: Universitat de Barcelona, 2006).

7 «Una polèmica sobre el català a les darreries del segle xviıI», «Pre-romanticisme i Pre-renaixença», respectivament. Faltaria anotar en aquesta llista les seves collaboracions a Hèlix, Mirador i La Veu de Catalunya. Afegim-hi també les seves contribucions a la premsa barcelonina en llengua espanyola, concretament a La Noche i El Día Gráfico, en què el 1927 va començar a escriure les seves primeres impressions sobre teatre. Vegeu Díaz-PlajA, Memoria de una generación, 79-83; Dámaso Santos, Conversaciones con Guillermo Díaz-Plaja, Sección Cultura, Serie Entrevistas 116 (Madrid: Novelas y Cuentos, 1972), 77.

8 «Notes sobre la lírica de Lope» (3 oct. 1935): 1-5; «La geografia de les líriques romàniques» (7 febr. 1936): 1-6. 
estudi sobre Garcilaso y la poesía española (1536-1936) a càrrec de la Universitat de Barcelona, el 1937.

En un altre ordre de coses, Díaz-Plaja va participar en cenacles i tertúlies literàries com ara la del Lyon d'Or, ${ }^{9}$ plataforma i llavor essencial del grup d'escriptors catalans que el 1939 es va convertir en la plana major del nou paradigma de la cultura oficial. En Díaz-Plaja en va oferir el primer indici en un text, «Mi Luys Santa Marina», publicat a Destino i aplegat més tard en el llibre Tiempo fugitivo:

A la nochecita, despuntada de focos, Luys nos esperaba en el viejo Lyon de la Rambla del Fin. Se sentaba al pie de una vieja armadura rodeada de estandartes. Traía bajo el brazo un libro oloroso a vejez o a tinta fresca. Mostraba unas viñetas antiguas o repetía un refrán de Quevedo. Hasta la madrugada era el palique. [...] Aquella noche - hace ya muchas (y se han transido de angustias muchas de ellas) - Loscertales traía el cartelón pintado para el viejo local de Falange. Luys había hecho grabar sobre las fechas recién nacidas esta frase latina: «Mortui morituros sperant».

— ¿Qué significa esto, Luys? - preguntó uno.

- Muy sencillo que los muertos esperan a los que han de morir. ${ }^{10}$

Com ha assenyalat Jordi Amat, l'article no era gratuït: «A la altura de 1940, aquel recuerdo le servía a Díaz-Plaja para legitimar, a pesar de su pasado republicano, la posición egregia que quería ostentar en la nueva sociedad cultural barcelonesa y española. [...] Con sus palabras certificaba que él había estado allí, compartiendo junto a dos falangistas de pro la maduración de la ideología de la victoria cuando era minoritaria y estaba proscrita». ${ }^{11}$

9 Entre altres, hi van participar Max Aub, Andrés Manuel Calzada, José Jurado Morales, Juan Ramón Masoliver, Félix Ros, Luys Santa Marina i Xavier de Salas: «De aquella tertulia salía una extraña revista titulada Azor, en la que se publicaban clásicos olvidados y versos modernos, y que después adquirió una rotunda significación política», DíAz-PlajA, Memoria de una generación, 131. Díaz-Plaja va publicar sengles articles a Azor (15 oct. 1932 i 15 març 1933). Vegeu també AMAT, «Memoria(s) de la tertulia del Lyon d'Or». Sobre Azor, vegeu José Carlos MAINER, «Azor (1932-1934): esquema de una crisis», dins La corona hecha trizas (1930-1960) (Barcelona: PPU, 1989), 103-119.

10 Tiempo fugitivo. Figuras y paisajes de 1940 (Barcelona: Las Ediciones de la Espiga, 1941), 29-30.

11 Амат, «Memoria(s) de la tertulia del Lyon d'Or», 24. 
En una situació distinta de la d'altres escriptors catalans, afectes a la nova causa política, que es devien sentir més còmodes en la Barcelona de finals de gener de 1939, Díaz-Plaja va haver de fer acte de contrició pública en relació amb el seu passat republicà. Ell no havia format part del Terç de Nostra Senyora de Montserrat, tampoc no havia canviat de bàndol durant el conflicte, ni havia participat en l'ocupació de Barcelona el 26 de gener. Quan va ser mobilitzat, es va incorporar a l'Agrupació d'Artilleria de Costes i posteriorment a la Milícia de Cultura de l'exèrcit republicà. ${ }^{12}$ Consegüentment, un cop acabada l'ocupació de Barcelona i Catalunya, va patir el corresponent procés de depuració com a professor que havia estat de la universitat i com a catedràtic d'institut. ${ }^{13}$ Va aconseguir la reintegració a la càtedra de segon ensenyament, però no va ser readmès a la universitat barcelonina, ${ }^{14} \mathrm{com}$ li va succeir també al seu mestre Valbuena Prat. ${ }^{15}$ Tanmateix, des del primer moment, la seva aproximació al nou règim polític i cultural es va posar ben de manifest en dissenyar la

12 José Cruset, Guillermo Díaz-Plaja, Grandes Escritores Contemporáneos 33 (Madrid: EPESA, 1970), 41-43; SAntos, Conversaciones con Guillermo Diaz-Plaja, 86.

13 «No es necesario que te explique que durante los primeros meses, se pasaron momentos de terrible amargura, ya que era muy difícil escapar de las reacciones apasionadas de aquel momento, y no deja de ser sorprendente e irritante que una gran parte de los que en aquellos [sic] me reprochaban mi poco fervor falangista, hoy me echen en cara mi poco fervor liberal. Estas y otras muchas consecuencias, te explicarán que los hombres de mi situación cronológica e histórica, tengamos como característica un radical escepticismo en nuestras actitudes políticas.», ibídem, 86-87.

14 «El nomenament d'un catedràtic exigia tenir un expedient impollut. Díaz-Plaja no el tenia. Potser per aquesta raó a començaments del febrer de 1940 el delegat provincial de Información e Investigación de Falange Española va demanar informes sobre ell. Els van redactar el degà de la Facultat de Filosofa i Lletres de la Universitat de Barcelona, el director de l'Institut Balmes i el president de la Comisión de Educación Nacional. Els dos primers van ser positius, però el tercer, escrupolosament documentat, va ser venjatiu i implacable: "Por sus antecedentes y actuación es persona en quien no debe depositarse confianza en cargo alguno. Se le puede considerar como un ambicioso desmesurado, y de ahí su colaboración con toda clase de regímenes”. Era una sentència definitiva. Potser mai no ho va tenir tan a prop, però se li havia vist massa el llautó», AMAT, «Fer-se franquista», 78.

15 Valbuena Prat va ser depurat i destinat a la Universitat de Múrcia. Díaz-Plaja va convertir el cas del seu mestre en un correlat objectiu de la seva exclusió de la universitat, a la qual no es va reincorporar fins a 1972 en el marc de l'Escola Universitària d'Alts Estudis Comercials de Barcelona. Vegeu Díaz-PlajA, "Ángel Valbuena Prat», dins Sociología cultural del posfranquismo, 146-149. Sobre la depuració de Valbuena Prat, vegeu Enrique SERrano Asensio, «Historia y punición», Revista de Literatura 135 (gen.-juny 2006): 249-259. 


\title{
substitució de l'Institut d'Estudis Catalans (IEC) per un nou organisme, l'Instituto Español de Estudios Mediterráneos. ${ }^{16}$
}

\section{Director interí de l'Institut del Teatre (1939-1941)}

\author{
Com va accedir Díaz-Plaja a la direcció de l'antiga Escola Catalana d'Art \\ Dramàtic, ${ }^{17}$ l'anomenada Institució del Teatre durant la guerra? El mes
}

16 Remeto a l'estudi detallat d'Olívia GASSOl I BELLET, De la utopia mediterrània a la realitat provincial. El projecte cultural de la Diputació de Barcelona durant el primer franquisme, Textos d'Història i Cultura 9 (Barcelona: Fundació Carles Pi i Sunyer, 2011), 13-43, especialment. En aquest sentit, el lector pot contrastar la interpretació distanciada i crítica que Díaz-Plaja va fer posteriorment dels «difíciles años cuarenta». Vegeu-ne una mostra: «En el caso que estamos analizando, habría que establecer en la España que "se quedó en casa" por lo menos dos zonas: la de los intelectuales vencedores en torno a los Servicios de Propaganda del Gobierno de Burgos — dirigidos por Dionisio Ridruejo-y los "vencidos" que se proponían, porque era lógico, vital y necesario, continuar existiendo, aun con la grave mutilación de la expresión en las lenguas no castellanas, que entonces empezaron a bautizarse con el curioso eufemismo de «vernáculas» [...] En el sector de la actividad cultural en la España posbélica, en efecto, los criterios eran cerradamente nacionalistas y si existieron deseos de iniciar una convivencia, como anota en sus Casi memorias el ya citado Ridruejo, la verdad es que no pudieron llevarlos a cabo. Dígase lo que se diga ahora, la impresión que recibíamos era la de que existía un monopolio cultural de nombres y de temas, y que, aun descontando cortesías en el trato particular en alguno de los vencedores - como recuerda Laín Entralgo-, es lo cierto que no se nos presentó entonces ninguna opción realmente favorable a la normalización cultural. [...] La obsesión nacionalista del momento agravaba todavía estos puntos de vista, enturbiándose en un tradicionalismo cultural que se cerraba a cualquier contacto europeo. Se diría que volvíamos a aquella España de Felipe II que se defendía, con un cinturón de castidad intelectual, contra la amenaza de factores disolventes. En relación con este cuadro de valores podríamos recordar la moda de las grandes figuras de la Contrareforma, y especialmente de Calderón de la Barca, cuyos "autos sacramentales" fueron puestos en circulación, con representaciones solemnes en las plazas públicas enlazando con una valoración de su obra que, antes de la guerra por cierto, habían iniciado Ángel Valbuena Prat, con sus estudios críticos, y Federico García Lorca con sus representaciones calderonianas en Granada. Por lo demás, se establecía una nueva escala de valores de carácter místico, que se apoyaba en la tradición castellana del Siglo de Oro, y que teñía las figuras de un catolicismo retórico que podía enlazarse en Europa, con el nombre de Paul Claudel. Don Eugenio d'Ors que, en la etapa anterior a la guerra, colaboraba en El Debate, servía perfectamente de punto-clave de una filosofía que encontraba su enlace en la militancia política de la Iglesia Española del momento. Y claro está que, dentro de esta línea, cabía toda la fidelidad reverente y la retórica peculiar de don José María Pemán. Nos llamaba también la atención, a los "vencidos", la temática necrofílica en uso que podríamos llamar de la voluptuosidad necrofílica. El grito de "viva la muerte”, en su feroz contrasentido, aparecía en la literatura bélica del momento, tristemente confirmada por la realidad de una mitología de los "caídos por Dios y por España”, DíAz-PlajA, Sociología cultural del posfranquismo, 33-36.

17 Sobre l'Institut del Teatre, vegeu Guillem-Jordi Graells, L'Institut del Teatre. 1913-1988. Història gràfica (Barcelona: Institut del Teatre, Diputació de Barcelona, 1990). Vegeu la segona edició 
de novembre de 1939, la Comissió Gestora de la Diputació Provincial de Barcelona el va nomenar director «provisionalmente». ${ }^{18} \mathrm{Al}$ marge de les consideracions i les decisions estrictament polítiques sobre el seu nomenament, quins mèrits específics podia argüir Díaz-Plaja en relació amb l'orientació exclusivament teatral del centre? Bàsicament, la direcció de la secció d’Art Dramàtic del Conservatori del Liceu entre 1933 i 1934, la publicació d'un llibre - L'evolució del teatre (1934)—, algunes collaboracions periodístiques i el seu interès concret pel teatre d'Azorín, emparentat amb la tradició maeterlinckiana, que va motivar un article el

amb l'aportació complementària de Xavier FEBRÉs, Institut del Teatre. Els primers cents anys 19132013 (Barcelona: Diputació de Barcelona, Institut del Teatre, 2015).

18 P. Bohigas Tarragó, Memoria de los cursos 1939-4o a 1942-43 (Barcelona: Instituto del Teatro. Diputación Provincial de Barcelona, 1944), 8. Anteriorment, el 5 d'octubre de 1939, l'actor Antoni de Gimbernat havia adreçat una carta al diputat ponent de Cultura en aquests termes: «Suplico a V. S. si lo estima en lo que vale en bien del arte, me conceda la Dirección del Instituto Nacional del Teatro de la Diputación Provincial de Barcelona, que se va a crear o, en todo caso, la Cátedra que sería la primera en su clase de España de "Tipología humana, aplicada al Teatro". Acompaño con la presente instancia un resumen de sugerencias, ampliable con estudios que tengo terminados, referente a la Institución que va a crearse. Dios salve a España y guarde a V. S. muchos años». Vegeu el «Resumen de mis estudios sobre la orientación del Teatro e Instrucción de los Actores, ampliable en el momento que se juzgue oportuno", A96/1, Arxiu Administratiu Històric del CDMAE de l'Institut del Teatre (a partir d'ara AAH). Poc després del nomenament interí de Díaz-Plaja, el 16 de novembre, la Tenencia de Alcaldía del Distrito I de Barcelona va adreçar una carta a l'«estimado Sr. [José de] Peray», un diputat tradicionalista de la Comissió Gestora de la Diputació de Barcelona: «Le adjunto la nota del Sr. Gimbernat y le reitero el ruego de que me interesa a mi o a mi compañero de Redacción, D. José $\mathrm{M}^{\mathrm{a}}$ Junyent, vernos con el sr. Riviére [diputat ponent de Cultura], pues al patrocinar al Sr. Gimbernat estamos seguros que prestamos un señalado favor al arte del teatro, toda vez que es persona de sólidos conocimientos y larga experiencia artística». El 22 de desembre, el nou director de l'Institut del Teatre, assenyalava: «Vista la precedente instancia, la Dirección que suscribe, en cumplimiento de la orden anterior, tiene el honor de informar manifestando que las sugestiones aportadas por el Sr. Gimbernat tienen efectivamente interés y merecerían que estuvieran en consideración para una institución de estudios dramáticos de actividades más amplias que las de nuestro Instituto del Teatro y que en el cuadro y dentro de los límites asignados a éste no tienen de momento lugar apropiado de aplicación». Gimbernat va continuar insistint en la creació d'una càtedra, que la direcció va denegar-li el 6 de febrer de 1940, car «no es aconsejable utilizar los indudables conocimientos del Sr. Gimbernat en forma de lección permanente, sino, en todo caso, en forma de conferencia o cursillo breve», A96/1, AAH. Sobre el tema, Guillem-Jordi Graells anota el següent: «Al setembre [1939], el diputat gestor de Cultura, Luis Rivière Manent, visità el local i emprengué les gestions per a la represa d'activitats, assessorat per Bohigas. En conseqüència calia, primerament, nomenar-ne un director i, tot i que s'havia ofert per al lloc l'actor i director Antoni de Gimbernat, el 12 de novembre de 1939 en fou designat Guillermo Díaz-Plaja», L'Institut del Teatre..., 85. 
1931. ${ }^{19}$ Un currículum de mèrits potser insuficient, però que en aquells moments el podia afavorir més que a qualsevol altre gestor de la institució teatral, supervivent de l'etapa republicana. Un organisme que va castigar el seu director, Joan Alavedra, amb l'exili, mentre que Adrià Gual, creador de l'Escola Catalana d'Art Dramàtic i director fins a 1934, acarava els seus últims anys amb una situació personal d'estricta supervivència. ${ }^{20}$ Segons Díaz-Plaja:

Adrià Gual podía, en su madura senectud, ser repuesto en la dirección, que durante la guerra había detentado Joan Alavedra; pero su nombre parecía, entonces, demasiado vinculado a la etapa «catalanista» de la institución, de una institución que, en cualquier caso, no podíamos dejar perecer. Pero yo pertenecía, también, al bando de los vencidos y había que esperar las decisiones de quienes, en aquel momento, asumían el poder. A nadie parecía preocuparle el tema. Hasta que un día me decidí visitar al ponente de cultura de la Diputación, Luis Rivière, para exponerle la necesidad de salvar un centro cultural que había prestado importantes servicios. Debí convencerle, porque, después de oírme, me preguntó sencillamente si yo me veía capaz de poner de nuevo en marcha el Instituto del Teatro. Acepté y me puse a la tarea. ${ }^{21}$

19 «Estudio sobre el teatro de Azorín», dins Azorín, Obras Completas: Teatro, II (Madrid, CIAP Renacimiento, 1931), 7-50.

20 Vegeu Enric GALLÉN, «Supervivència i mort d'Adrià Gual, un home de teatre (1939-1943)», Els Marges 100 (primavera 2013): 61-74.

21 «En torno al Teatro», dins Retrato de un escritor (Barcelona: Editorial Pomaire, 1978), 238-239. Luis Rivière Manén (1897-1980), vinculat a la burgesia barcelonina, havia contactat amb Roberto Bassas, un dels dirigents falangistes barcelonins de la primera hora. El ponent de Cultura i Belles Arts de la Comissió Gestora de la Diputació Provincial era cunyat de José Ribas Seva, un dels caps falangistes catalans més representatius del moment en els àmbits local i estatal. El 5 d'octubre de 1940 Rivière va ser substituït per José Bonet del Río, que va ocupar el càrrec fins al 21 de maig de 1942, quan Antonio Salas Amat es va convertir en el nou ponent de Cultura i Belles Arts. Posteriorment, el 23 de desembre de 1943, Salas va ser reemplaçat per Diego Ramírez Pastor. Vegeu P. Bohigas TaRrAGó, Memoria del curso 1943-44 (Barcelona: Instituto del Teatro. Diputación Provincial de Barcelona, 1944), 5. El 13 d'octubre de 1944, es va modificar la composició de la Comissió Gestora, i José Maluquer Cueto va substituir Ramírez Pastor en la Comissió de Cultura i Belles Arts. P. Bohigas TarRAGó, Memoria del curso 1944-45 (Barcelona: Instituto del Teatro. Diputación Provincial de Barcelona, 1944), 6. El maig de 1945, Maluquer Cueto va cessar com a diputat ponent de Cultura i al seu torn va ser substituït per Luis de Caralt, i el «2o de septiembre de 1945 fue nombrado para el mismo cargo don Pedro Abadal Botanch.» Quan el gener de 1946 va ser nomenat un nou president de la Comissió Gestora, Antonio M. Llopis Galofré, en substitució de Luís Argemí y de Martí, Ramón Forcada Ramo- 
No sé si va anar exactament com ho explica Díaz-Plaja, però el que ara i ací paga la pena de consignar són els criteris de la seva actuació en els dos primers anys com a director «interí» de l'Institut del Teatre. La «tarea» de què parla va estar òbviament condicionada i modelada per les circumstàncies polítiques del moment. Entre els papers de Díaz-Plaja, que formen part del seu arxiu dipositat a la RABLB, es conserven unes fitxes petites escrites en llengua espanyola, datades el mes de novembre de $1939,{ }^{22}$ en què exposa les seves línies d'actuació immediata en un organisme que va passar a dir-se «Instituto del Teatro», un nom ja imposat durant la dictadura de Primo de Rivera entre 1927 i 1930, i que es va recuperar en dependre novament de la Diputació Provincial de Barcelona després dels anys de vinculació a la Generalitat republicana.

El programa d'intervenció que plantejava Díaz-Plaja en les esmentades fitxes afectava quatre àmbits:

1. Renovación del local: a) aspecto político (1. letreros. 2. nombre de la institución. 3. retratos y banderas). b) organización eficaz (1. sala de profesores (su necesidad). 2. secretaria. 3. biblioteca. 4. Dirección.)

2. Biblioteca: a) ausencia de autores españoles, b) necesidad de una depuración, c) desorden, d) nueva instalación, e) nombramiento bibliotecarias, f) selección y especialización, y g) apertura al público.

3. Publicaciones: a) necesidad de las mismas (1. Cuadernos del Instituto. 2. Ediciones y estudios), b) la función difusora y erudita.

4. Personal. A revisar: Bohigas*, Gual*, Pena*, Mestres*, Genescà ${ }^{*}$, Batlle*. A proponer: M. Grau. Carbonell. 2 bibliotecarias. 1 mecanógrafa. ${ }^{23}$

neda es va convertir en el nou ponent de Cultura, amb José Emilio de Maqua y Sagnier, de suplent. Pere Bohigas Tarragó, Memoria del curso 1945-46 (Barcelona: Instituto del Teatro. Diputación Provincial de Barcelona. Conservatorio Superior de Barcelona, 1946), 5. Sobre el funcionament de la Diputació Provincial de Barcelona de la postguerra, vegeu Carme Molinero \& Pere Ysàs, «La Diputació de la postguerra 1939-1949» i «De la consolidació del franquisme a la crisi de la Dictadura: la Diputació de 1949 a 1977», dins Borja de RiQuer, dir., Història de la Diputació de Barcelona (18122005), III: 1939-2005 (Barcelona: Diputació de Barcelona, 2007), 9-45 i 47-111, respectivament.

22 Arxiu Díaz-Plaja, Institut del Teatre, RABLB.

23 Joan Batlle va ser readmès com a conserge (10 novembre 1939), càrrec que ja ocupava abans de 1939. Aquesta situació no es va donar en el cas de Marcellí Genescà i Oliveras, auxiliar de secretària que s'havia incorporat a files el 19 de juliol de 1937. Vegeu Francesc Foguet i Boreu, «La Institució del Teatre durant la guerra i la revolució (1936-1937)», Revista de Catalunya 199 (oct. 2004): 134. 
El 12 de novembre de 1939 Díaz-Plaja va ser designat director de l'Institut del Teatre i el 24 del mateix mes va fer arribar al «diputado ponente de Cultura», Luis Rivière Manén, un «Proyecto de Presupuesto para 1940», ${ }^{24}$ en què manifestava el «deseo de que nuestro Instituto, además de una escuela de las profesiones relativas a la manifestación teatral, sea un laboratorio de estudios dramáticos que, vigorizando y enalteciendo esta rama, esencialmente nacional, de la literatura, constituya un elemento eficaz y fecundo de la cultura patria». Em sembla important destacar la referència a les despeses extraordinàries (25.00o pessetes per $17.000 \mathrm{de}$ despeses ordinàries) destinades a la installació de la Biblioteca i del Museu; la reinstallació de l'enllumenat i la calefacció en l'edifici de tres plantes del carrer d'Elisabets, número 12, i altres feines de paleta. Quant als sous del personal, quedava clar que «si bien son iguales a los que regían en 1936, son asimismo iguales a los de 1930 y aun a los de 1918, pues desde esta última fecha no han sufrido aumento alguno».

Díaz-Plaja va establir una partida específica per a publicacions «informativas y didácticas», conferències, representacions, cursets, exposicions, recitals $i$ «otros actos educativos», i va abonar la seva sollicitud en els termes següents:

Se refieren estas atenciones a unas actividades que reputo de importancia primordial. La simple dotación técnica de las personas que deseen dedicarse a la profesión de actor o de escenógrafo, constituye, sin duda, una apreciable aportación al arte dramático nacional; pero este tributo, no es el elemento fundamental del teatro que en la nueva España ha de continuar su gloriosa tradición. Para que esta tradición reviva y continúe con fuerza propia es necesario aclimatar al público a los valores positivos de aquella dramática y aún de todas las que han alcanzado o alcanzan legítimo prestigio más allá de nuestras fronteras. Para ello es preciso conocer la opinión de los doctos y los eruditos; divulgar, con la mayor amplitud posible, estas opiniones; y poner de relieve, ante el público, el mérito y las bellezas de las grandes obras del teatro clásico y moderno.

El 12 de desembre de 1939, Concepció Cabestany Nickel va ser nomenada mecanògrafa. Vegeu BoHIGAS, Memoria de los cursos 1939-40 a 1942-43, 8.

24 Arxiu Díaz-Plaja, Institut del Teatre, RABLB. 
El curs va començar el 8 de gener de 1940 amb els ensenyaments organitzats entorn de dues seccions, Declamació i Escenografia, amb alguns canvis importants en el claustre docent. Quant al professorat nomenat per la Generalitat republicana, «dejaron de pertenecer los profesores y funcionarios del mismo, a excepción del profesor don Enrique Giménez y el secretario, don P. Bohigas Tarragó, que fueron confirmados en sus cargos, por haber sido nombrados para los mismos por la Diputación Provincial en 1913 y 1915, respectivamente». ${ }^{25}$

Atès que Enric Giménez, professor de Declamació, havia mort el 26 de maig de 1939, quan Díaz-Plaja va iniciar la reorganització del centre ja no hi va poder comptar, ni tampoc amb August Barbosa, auxiliar de Giménez, que havia estat depurat; ${ }^{26}$ en canvi, Josep Mestres Cabanes, deixeble de Salvador Alarma, ${ }^{27}$ va ser readmès com a professor d'Escenografia. Les

25 Bohigas, Memoria de los cursos 1939-4o a 1942-43, 8. Segons la Resolució del 10 de febrer de 1940 del jutge instructor, Salvador Viada, Pere Bohigas Tarragó, secretari de la institució, va ser sancionat i suspès de sou i feina durant sis mesos. Oficialment no va recuperar la seva plaça de secretari, que havia estat coberta interinament per Ramon Picó, fins al mes d'agost d'aquell any. Vegeu A-96/1, AAH. Díaz-Plaja explica que va voler mantenir «a mi lado, desde el primer momento, Pere B. Tarragó, que comprendió el espíritu de salvación que me animaba y me sirvió lealmente hasta su muerte», Retrato de un escritor, 238. Bohigas va morir el 7 de juny de 1948 en el transcurs d'un homenatge ofert per la institució, «que representava un acte de reintegració i de reconeixement després dels anys obscurs», Oriol BoHIGAs, «El meu pare durant la guerra i la postguerra», dins Combat d'incerteses. Dietari de records, Biografies i Memòries 11 (Barcelona: Edicions 62, 1989), 52. Vegeu també Ramón Picó Capdevila, Memoria del curso 1947-48 (Barcelona: Instituto del Teatro. Diputación Provincial de Barcelona. Conservatorio Superior de Barcelona, 1948), 10-11, i A-28, AAH.

26 Va morir el 5 de desembre de 1941. Vegeu Bohigas, Memoria de los cursos 1939-40 a 194243, 17. Antoni de Gimbernat, que va ser nomenat professor auxiliar de Declamació el 28 de febrer de 1941, va presentar la dimissió el mes d'octubre del mateix any (vegeu ibídem, 16). El 7 d'octubre, Díaz-Plaja va fer una proposta de substitució de Gimbernat que no em consta que s'arribés a produir: «D. Emilio Ribas Vela, profesor de Arte, con certificado de estudios superiores de la Universidad de París y de la Escuela de Louvre. Dicho profesor podría percibir la remuneración acordada al profesor cuya vacante pasaría a ocupar», A-96/2, AAH. El cessament de Gimbernat es va fer efectiu el 10 de novembre de 1941. Posteriorment, per al curs 1942-1943 es va contractar Bartomeu Olsina (vegeu BoHIGAs, Memoria de los cursos 1939-4o a 1942-43, 18). Olsina ja havia estudiat a la institució durant l'etapa republicana, en què va ser alumne d'August Barbosa com a professor de Declamació.

27 Va morir el 26 de març de 1941. A partir del curs 1942-1943, però amb efectes retrospectius per al curs 1941-1942, es van crear els premis extraordinaris Enric Giménez i Salvador Alarma, de declamació i escenografia, respectivament, per als millors alumnes que acabessin els estudis regulars en les dues seccions. A partir de 1949 s'hi va afegir el premi extraordinari Ricard Moragas per a l'alumnat de la Secció de Dansa. La relació dels premis Enric Giménez va ser la següent durant aquest període: Maria Joana Ribes (1942), Mercedes López Collado (1943), Assumpció Balaguer 
dues persones que el nou director va proposar - Marta Grau i Artur Carbonell - van ser acceptades. En el cas de Grau també es tractava d'una readmissió, car procedia del Conservatori del Liceu, d'on havia estat professora de Declamació castellana des de 1933 fins que durant la guerra va ser traspassada a impartir la mateixa docència a la Institució del Teatre. ${ }^{28}$ Artur Carbonell, artista i director escènic, provenia del teatre de cambra més renovador dels anys trenta. Amb el seu grup de Sitges havia estrenat Orfeu de Cocteau, i amb el Lyceum Club de Barcelona havia dirigit Txèkhov, Strindberg, Pirandello, Lenormand, Shaw o O’Neill, en català. ${ }^{29}$ Entre els papers dipositats a l'Arxiu Díaz-Plaja es conserven unes quartilles mecanografiades de caràcter programàtic de Carbonell sobre la feina que pretenia realitzar com a responsable dels ensenyaments de Dibuix i Realitzacions Escèniques. Les esmentades quartilles acompa-

(1944), Aurora Bautista (1945), Francesc Aliot (1946), Teresa Cunillé (1947), desert (1948), Carlos Lucena (1949), Joaquim Nicolau (1950). La relació del premi d'Escenografia va ser la següent: Laureano Higueras (1942), Joan Vilajuana Bertolín (1943), desert (1944), Santiago Brugalla Aurignac (1945), Emili Berenguer Santisteve (1946), Jaume Font Borràs (1947), desert (1948, 1949), Josep Gual Bernadas (1950). El premi de Dansa va ser atorgat a Aurora Pons (1949). Els cursos 1950-1951 i 1951-1952 no es va concedir cap premi extraordinari.

28 Vegeu Francesc Foguet i Boreu, «La Institució del Teatre», 16. Amb data de 2 de gener de 1940, va sollicitar la plaça de professora de Declamació, que també va ser reclamada per Antoni Piera. Grau, de quaranta-vuit anys, disposava de "carnet de la FET y de las JONS n ${ }^{\circ} 6499$ ". Un dels avals, datat l'11 de febrer de 1939, corresponia a Fausto Santa-Olalla Murciano, un «capitán de Infantería retirado extraordinario, actualmente a las órdenes del Excmo. Sr. Vicepresidente del Gobierno y Ministro de Asuntos Exteriores [que] avala a Doña Marta Grau y Porta, como persona de derechas, de sentimientos religiosos, y afecta por tanto al Glorioso Movimiento Nacional». Una dada familiar: un altre Santa-Olalla Murciano estava casat amb Montserrat Grau Porta, germana de l'actriu i professora, i mare alhora de l'actriu Marta Santa-Olalla Grau, que va arribar a ser catedràtica de Dicción y Lectura expresiva a la Real Escuela Superior de Arte Dramático de Madrid (vegeu A-96/1, AAH).

29 Juan Ramón Masoliver, cap provincial de Propaganda, va certificar el seu aval: «Por lo que atañe a su ideología puedo decir que le consideré siempre persona de derechas y católica y apartada de la política militante, dedicado por entero a sus actividades artísticas. Me consta igualmente el trato vejatorio que le dieron los rojos y que su abastecimiento en el período de dominación de éstos llegó al punto de no querer figurar en exposición de arte alguna. Y sé, también, que cuando el avance nacional desde Lérida, pasó por el frente a las filas nacionales, a principios de enero del año en curso. Todo lo cual firmo, por ser cierto, en Barcelona a 6 de diciembre 1939. Año de la Victoria», A-96/1, AAH. Sobre Carbonell, vegeu Isabel ARTIGAS CoLL, «Artur Carbonell i Carbonell. Una vida dividida entre dues passions, el teatre i la pintura», Assaig de Teatre 18-20 (des. 1999): 31-48; Enric Gallén, "“Teatro del Arte" (1941-1950), de Marta Grau i Artur Carbonell», dins El teatre a la ciutat de Barcelona durant el règim franquista (1939-1975), Monografies de Teatre 19 (Barcelona: Edicions 62/Publicacions de l'Institut del Teatre, 1985), 201-207. 
nyaven el seu currículum, en què totes les seves produccions en català havien estat degudament traduïdes a l'espanyol. La documentació es completava amb un parell de crítiques elogioses de muntatges seus dels anys trenta de dos escriptors afectes al nou règim: Félix Ros a La Vanguardia i Ignacio Agustí a La Veu de Catalunya; en aquest cas, l'article va ser traduït també a l'espanyol.

El context va condicionar també la redacció del programa de Carbonell, farcit de referències al teatre estranger, de tal manera que, a l'hora de cloure la seva proposta, ho feia de manera significativa en clau nacional:

He aquí expuesta mi concepción de cual debe ser la norma en un Instituto del Teatro. El punto final del programa debe ser éste:

No empezar un curso, una temporada, bajo los mejores augurios para, al cabo de un mes, ir vegetando con sólo el deseo de acabar cuanto antes. Hay que luchar siempre, con denuedo, sin sentir los desfallecimientos de la gente de poca fe, en la mitad de su carrera.

Para ello, edifiquemos nuestro edificio sobre los mejores cimientos: Calderón, Cervantes, Lope, Alarcón. ${ }^{30}$

No hi havia altra volta de full possible. Com tants altres, Carbonell va passar l'examen d'afecció a la nova situació política. Per aquesta raó, devia triar les crítiques de Ros i Agustí i esmentava la tradició dramàtica espanyola. Un nou professor, Ramon Picó Capdevila, es va incorporar com a auxiliar d'Escenografia, i es va contractar Ramona Masvidal com a bibliotecària en substitució de Joaquim Pena, que ho era de 1932 ençà. ${ }^{31}$ Encara que ja havia complert seixanta-sis anys, Pena no podia «alegar un número de años de servicio que le dieran derecho reglamentario a la jubilación a que desde un punto de vista moral resulta tan legítimamente acreedor». Davant d'aquesta situació, Díaz-Plaja va demanar al ponent de Cultura un tracte de favor per al «traductor del maestro [Wagner] de

30 Arxiu Díaz-Plaja, Institut del Teatre, RABLB.

31 Va presentar la dimissió el 25 de maig de 1942, i el 25 de setembre d'aquell mateix any Candelària Roig va ser designada com a nova bibliotecària i, posteriorment, va ser inscrita a la plantilla. Vegeu BoHigas, Memoria del curso 1943-44, 6. 
Bayreuth», tot recordant que en plena situació bèllica i revolucionària, l'1 de juliol de 1937, Pena havia fet donació a la Institució del Teatre de la seva biblioteca de més de 10.000 volums, «en su mayor parte dedicados a temas de literatura y de música dramática y especialmente al teatro de Wagner».32 La sollicitud de Díaz-Plaja, acordada amb Felipe Mateu Llopis, director de la Biblioteca de Catalunya (batejada amb el nom de Central a partir de 1939), va ser acollida i acceptada per la Comissió Gestora de la Diputació Provincial. ${ }^{33}$

En les seves primeres actuacions i gestions com a director, Díaz-Plaja va saber moure's i actuar amb diligència i habilitat tàctica, ${ }^{34}$ en un context en què el seu perfil polític generava suspicàcies en la família política falangista. En aquest sentit, cal esmentar un incident que ha estat estu-

32 Amb data del 24 de juliol de 1941, tot fent referència a la seva situació d'«ex-funcionario encargado de la Biblioteca, Archivo y Museo del Instituto del Teatro que sostiene esa Diputación Provincial y actualmente pensionado por la misma en atención a mi delicado estado de salud y a los servicios prestados (según acuerdo de 19 de enero de 1940)», Joaquim Pena va confirmar el donatiu. Tanmateix, va exposar una modificació sobre la destinació del seu llegat a la consideració del president de la Comissió Gestora de la Diputació Provincial: « $1^{\circ}$.- Que el Instituto del Teatro entregue al Departamento de Música de la Biblioteca Central todos los libros, partituras, documentos y material iconográfico referentes a materias musicales, en sus diversos aspectos, procedentes de mi colección particular. $2^{\circ}$.- Que continúen en el propio Instituto las restantes obras literarias y el material no concerniente a la música. $3^{\circ}$.- Que, a pesar de mi especial deseo de que la colección wagneriana siga formando un conjunto inseparable, pueda desglosarse de ella y conservar en depósito el Instituto del Teatro toda la sección titulada "Escenografía wagneriana" para facilitar su conocimiento y estudio a los alumnos de las clases de escenografía que se dan en dicho Instituto, mientras subsista allí esta enseñanza», A-97/22, AAH. En la sessió del 31 d'octubre de 1941, la Comissió Gestora de la Diputació Provincial va acordar la cessió de l'Institut del Teatre a la Biblioteca de Catalunya de tota la documentació de matèries musicals, i el lliurament de la Biblioteca de Catalunya a l'Institut del Teatre d'«el grupo de obras sobre teatro y literatura dramática que posee». Sobre la situació de Pena durant el període revolucionari, vegeu també Anna CostAL \& Joaquim RABASSEDA, «La tragèdia d'un wagnerià i la FAI», L'Avenç 359 (jul. 2010): 28.

33 El repartiment i consegüent classificació dels materials assignats per la Biblioteca de Catalunya i l'Institut del Teatre es va realitzar entre els mesos de febrer i març de 1943 (vegeu A-97/22, AAH).

34 Un cop establerta la plantilla bàsica de funcionament de l'entitat, el 4 de novembre de 1940, Díaz-Plaja va enviar una carta al diputat ponent en què exposava els sous anuals del personal: el director (6.00o), el secretari Bohigas (3.00o), el professorat -Grau, Carbonell i Mestres (3.60o), Picó (1.80o) - , la bibliotecària Masvidal (2.500), la mecanògrafa Cabestany (2.400) i el conserge Batlle (2.00o). Feta la relació, Díaz-Plaja anotava: «Este personal figura en calidad de "servicios prestados", a excepción de Don Pedro Bohigas Tarragó que figura "en nómina" por pertenecer a este Instituto con anterioridad a su actual reorganización. Los sueldos tipo que percibe el personal afecto a este Instituto del Teatro no han sido modificados desde 1918", A-96/1, AAH. 
diat per Jordi Amat.35 El 1941 Díaz-Plaja va publicar l'assaig La poesía y el pensamiento de Ramón de Basterra, un escriptor basc mort el 1928 l'obra del qual havia estat manllevada per la Falange com a suport del seu discurs ideològic. La recepció crítica va ser molt dura amb el contingut del llibre. El crític i professor Joaquín de Entrambasaguas ${ }^{36}$ va deixar en evidència l'oportunisme polític de Díaz-Plaja, però la crítica d'un enigmàtic G de la revista Escorial, dirigida per Pedro Laín, que feia ironia al principi i al final de la ressenya de la «derramada producción» de Díaz-Plaja, va ser encara més dura, car no afectava només el contingut sinó també l'estil, perquè «este libro está escrito con la torpeza de quien no escribe en lengua materna, sino en lengua de extranjería». Per Amat:

Argüir en contra de un escritor mediante esta otra falacia - ya van dos: ¡quién sabe si agnóstico y, por si era poco, catalán! - tampoco era inocente. Díaz-Plaja había tendido y tendería puentes de diálogo entre escritores de todas las lenguas de España (también de la cultura hispánica, desde Hispanoamérica hasta los sefardíes), pero a la altura de 1941, sólo la pureza ideológica posibilita la presencia en la vida pública y Díaz-Plaja — «quien profesa diaria-

35 Jordi AMAT, «Guillermo Díaz-Plaja lee a Ramón de Basterra (1941): Un episodio de la cultura fascista española», Insula 696 (des. 2004):11-17, http://www.ub.edu/filhis/documentsweb/becarios/ materiales/jordi/diazplajabasterra.pdf.

36 Joaquín de Entrambasaguas (1904-1995) havia participat en el creuer per la Mediterrània de 1933. Malgrat el seu pes polític en els primers anys de la postguerra, va assumir interinament la càtedra d'Historia de la Lengua Castellana a la Facultad de Filosofía y Letras de la Universidad de Madrid fins que li va ser adjudicada el 1946. Es conserven un parell de cartes adreçades a Díaz-Plaja, relacionades amb les seves aspiracions acadèmiques. Entrambasaguas apareix com a mediador seu prop de José Ibáñez Martín, ministre d'Educació: «por fin he conseguido del ministro que te nombre para la cátedra de la Universidad de Barcelona como deseabas y te prometí procurar. Y a pesar de que varias personas, incluso el Rector [Emilio Jimeno Gil] se oponían. Aunque aún no es público se me ha dicho como seguro. Así pues paciencia — buena - y discreción — larga — hasta que esté en el B[oletín] O[ficial].», carta del 7 de desembre de 1939. Dos anys més tard, la pretensió de Díaz-Plaja s'havia fet fonedissa: «De la cátedra de Barcelona me abstengo de hablar hasta que nos veamos para que te conste que yo luché por lo que deseaba con todas mis fuerzas como lo sabe [Marqués del] Saltillo [Javier Lasso de la Vega, degà de la Facultad de Filosofía y Letras], quien tampoco no sale de su asombro», carta del 13 de novembre de 1941, dins Jordi Amat Fusté, Blanca Bravo Cela \& Ana DíazPlaja Taboada, ed., Querido amigo, estimado maestro. Cartas a Guillermo Díaz-Plaja (1929-1984) (Barcelona: Publicacions i Edicions de la Universitat de Barcelona, 2009), 67 i 87, respectivament. El 1942 la càtedra en qüestió va ser ocupada pel professor José $M^{\mathrm{a}}$ Castro y Calvo, que procedia de la Universitat de Saragossa. 
mente Lengua castellana en una Institución del estado y escribe libros de texto para uso de escolares» - llevaba en los genes la catalanidad. ${ }^{37}$

Que la crítica li va doldre, n'és mostra la «Carta abierta al Sr. G.», que va publicar en la seva columna «La saeta en el aire» de Destino, en què va revelar que «Sagitario» era «Guillermo Díaz-Plaja». ${ }^{3}$

Abans de la convocatòria del concurs oposició per cobrir «en propiedad» la plaça de director de la institució de manera definitiva, Díaz-Plaja va tirar endavant un parell d'iniciatives amb l'objectiu de regularitzar i ajustar el perfil professional i docent de l'Institut. En primer lloc, el 1940, el Conservatori del Liceu i l'Institut del Teatre van decidir coordinar els graus d'ensenyament de Declamació castellana dels dos centres. El Conservatori admetria en les classes de Declamació els alumnes menors de catorze anys, i l'Institut acolliria els alumnes de més edat que passarien a estudiar directament els cursos superiors. En segon lloc, el mes de juliol de 1941, el Sindicato de Espectáculos de la Central Nacional Sindicalista, «a instancias de nuestro director», 39 va acordar concedir de manera automàtica, sense el requisit d'un aprenentatge previ, el carnet sindical als alumnes de l'Institut que haguessin acabat els cursos reglamentaris i obtingut el títol de fi d'estudis.

37 Jordi Amat, «Guillermo Díaz-Plaja lee a Ramón de Basterra...», 16.

38 En el postfranquisme, Díaz-Plaja ho va explicar en aquests termes: «La tabla de valores contemporáneos se ceñía a las figuras que, de alguna manera, habían sido premonitorias de la España Nacional, que podían simbolizarse en aquel grupo de intelectuales de Bilbao, los de la tertulia de Pedro Eguilor que, con Ramón de Basterra al frente, Sánchez Mazas, Quadra Salcedo, Lequerica o Mouriane Michelena, junto a Giménez Caballero, Víctor de la Serna o Eugenio Montes, crearon una mitología llena de signos romanos e imperiales, que tenían su retórica presencia en la "revista negra" de la Falange, Jerarquía, que se publicaba en Pamplona. Pero aun estos valores se utilizaban de una forma monopolista y excluyente. Y no puedo dejar de recordar que, cuando movido por mi vocación de crítico, intenté un estudio objetivo de la obra de Ramón de Basterra recibí, desde la revista Escorial, uno de los más brutales e injustos ataques que puedan dirigirse a un escritor - ataque que apareció además como semianónimo, y en un momento en que me era imposible toda réplica. La obsesión nacionalista del momento agravaba todavía estos puntos de vista, enturbiándose en un tradicionalismo cultural que se cerraba a cualquier contacto europeo. Se diría que volvíamos a aquella España de Felipe II que se defendía, con un cinturón de castidad intelectual, contra la amenaza de factores disolventes», DíAz-PlajA, «Difíciles años cuarenta», dins Sociología cultural del posfranquismo, 34-35.

39 BoHIgAs, Memoria de los cursos 1939-40 a 1942-43, 15. 


\section{La convocatòria del concurs oposició a la direcció de l'Institut del Teatre (1941)}

Segons un acord de la Comissió Gestora de la Diputació Provincial del 28 de març de 1941, es va decidir proveir les places de director de l'Institut Psicotècnic, la Residència d'Estudiants i l'Institut del Teatre. De manera preceptiva, els candidats havien de reunir, entre altres, les següents condicions: «ser ciudadano español»; «acreditar la más absoluta adhesión al Glorioso Movimiento Nacional»; «certificado del registro central de penados y rebeldes que acredite no haber sufrido condena ni estar declarado en rebeldía»; «certificado de adhesión al Glorioso Movimiento Nacional expedido por la Delegación Provincial de Información e Investigación de FET y de las JONS. O bien por alguna Autoridad o dos avales de suficiente garantía; o carnet de militante en dicha Organización del Movimiento». En el cas de l'Institut del Teatre es van considerar, a més, uns «méritos especiales para establecer preferencias entre los concursantes»:

a) Ser militante de FET y de las JONS.

b) Poseer una destacada personalidad artística públicamente reconocida.

c) Haber sido distinguido con premios o menciones honoríficas durante el ejercicio profesional.

d) Haber sido profesor de conservatorio o entidad análoga relacionados con el teatro.

e) Poseer un título académico.

I afegia:

$7^{\mathrm{a}}$.- En el caso de igualdad de méritos entre los concursantes el Tribunal podrá someterlos a una doble prueba consistente en la redacción de una memoria descriptiva de la reorganización del Instituto y en la explicación de una lección de la especialidad teatral que escoja el concursante. ${ }^{40}$

40 Q-569/48, AGDB. 
La convocatòria pública del concurs ${ }^{41}$ va aparèixer al Boletín Oficial del Estado el 23 de maig,,42 però al cap d'uns quants dies es van haver de corregir dos errors que afectaven les bases za i ga, que van quedar redactades, finalment, en els termes següents:

$3^{\mathrm{a}}$.- El Tribunal o Jurado que ha de fallar el presente concurso-oposición y elevar la propuesta de nombramiento correspondiente estará integrado por un Presidente, que será el Iltre. Sr Diputado Ponente de Cultura, Don Fernando Valls y Taberner, Director de la Escuela de Bibliotecarias y Académico de la Real Academia de Bellas Letras; Don Luis Masriera, miembro de la Real Academia de Bellas Artes de San Jorge; un representante de la Sociedad de Autores y un representante del Sindicato Teatral. Actuará de Secretario el Jefe de la Sección de Cultura de esta Diputación Provincial.

$9^{\mathrm{a}}$.- Los admitidos a la oposición abonarán en concepto de derechos la cantidad de 25 pesetas, una vez declarados útiles. ${ }^{43}$

\section{Els candidats}

El 4 de juliol de 1941 va tenir lloc la primera reunió amb l'assistència de José Bonet del Río, diputat ponent de Cultura de la Diputació Provincial de Barcelona; Fernando Valls Taberner, com a director de l'Escola de Bibliotecàries i membre també de la Reial Acadèmia de Bones Lletres de Barcelona; Luís Masriera, com a representant de la Reial Acadèmia de Belles Arts de Sant Jordi i alhora de la Sociedad de Autores; Lope F. Martínez de Ribera, com a representant del Sindicato del Espectáculo de la Central Nacional Sindicalista(CNS), i Joaquín Gorgot, cap de la Secció de Cultura, que va fer de secretari.

41 Vegeu l'annex 1.

42 BOE 143, 23 maig 1941, 2094-2095.

43 BOE 162, 11 juny 1941, 2394. S'hi observa un error: Valls Taberner era acadèmic de la Reial Acadèmia de Bones Lletres [Buenas Letras] i no de «Bellas Artes». En la base tercera, se substituïa el nom d'Artur Masriera pel de Luis Masriera, i en la base novena, la quantitat de 23 pessetes es canviava per la de 25 pessetes (vegeu Q-571, AGDB). 
El tribunal va haver d'examinar les instàncies i la documentació presentades pels candidats següents: Ramón Amat Artigas, Guillermo DíazPlaja, Joaquín Vidal Nunell, Antonio de Gimbernat, Fernando Lope de Castro y Fernández de Alvarado, Juan Porta Sarret, José $\mathrm{M}^{\mathrm{a}}$ Junyent Quintana i Valentín Moragas Roger.

Els vuit candidats a la plaça de director de l'Institut del Teatre responien a perfils molt distints, segons es desprèn del resum de la documentació que van presentar. ${ }^{44}$ Passem llista. Ramón Amat Artigas era llicenciat en Filosofia amb data del 13 de març de 1938, segons el certificat de The Superior Regular de la Misión de Bombay. Havia treballat com a professor i com a prefecte d'Internat, Disciplina i Esports al St Mary's High School de Bombay. Com a mèrits personals, aportava la seva activitat docent al Real Colegio-Monasterio de Nuestra Señora de Veruela (província de Saragossa) i al Castello de Bollengo (Aosta) durant cinc anys. Afegia també que «bajo la dirección de los P.P. de la Compañía de Jesús enseñó Literaturas española y catalana durante el curso escolar 1935-1936 y Psicología y Pedagogía en el Colegio de Preparación Universitaria de Cambridge (Bombay)». Amat, que presentava «un resguardo para recoger el carnet de Falange Española Tradicionalista y de las JONS», no aportava cap mena d'aval.45 L'expedient de Díaz-Plaja era el més complet de tots els candidats i el que hi contribuïa amb més documentació tant en relació amb els «méritos personales» ${ }^{46}$ com amb els «méritos especiales». Quant als títols, esmentava el de catedràtic numerari de Literatura "por oposición directa» a l'Institut Balmes, i els de «Doctor en Filosofía y Letras, sección de Letras, Licenciado en la misma Facultad, Maestro Nacional y Bachiller». Presentava els avals de Luys Santa Marina i Juan Ramón Masoliver, ${ }^{47}$ tres certificats - el del Conservatori del Liceu, signat per Fernando Valls Taberner, ${ }^{48}$

44 «Resumen de la documentación presentada por los señores que a continuación se expresan: $\mathrm{N}^{\mathrm{o}}$ 1.- Don Ramón Amat Artigas. $\mathrm{N}^{\circ}$ 2.- Don Guillermo Diaz Plaja. $\mathrm{N}^{\mathrm{o}}$ 3.- Don Joaquín Vidal Nunell. $4^{\text {a }}$-- Don Antonio de Gimbernat Ballvé. $5^{\circ}$.- Don Fernando Lope de Castro y Fernández de Alvarado. $6^{\circ}$.- Don Juan Porta Sarret. $7^{\circ}$.- Don José María Junyent Quintana. No 8.- Valentín Moragas Roger», Q-569/48, AGDB.

45 Ibídem.

46 Vegeu l'annex 2.

47 Vegeu els annexos 3 i 4.

48 Vegeu l'annex 5 .

FRANQUISME \& TRANSICIÓ 3 (2015) ISSN 2014-511X PUNCTUM, UNIVERSITAT OBERTA DE CATALUNYA \& FUNDACIÓ CARLES PI I SUNYER 
el d'Amadeo Posat Laverriere, secretari de l'Institut Jaume Balmes, i el de Jorge Vila Fradera, cap del Departament de Premsa, Propaganda i Relacions del Districte Universitari de Catalunya i Balears-, i un «resumen de la labor realizada, como actual Director en el Instituto del Teatro y Documento acreditativo del aumento de matrícula durante su gestión». En l'apartat dels mèrits personals, el redactor del resum destacava el següent:

Posee una destacada personalidad. Su obra literaria abarca unos treinta volúmenes, una gran parte de los cuales tratan de historia y crítica teatral. Ha obtenido constantemente premios y calificaciones extraordinarias, notaremos las principales: Primer Premio Nacional de Literatura (1935), Premio Extraordinario de Filosofía y Letras. Premio Rivadeneyra. Premio Único para la Crítica Teatral. Ha dirigido durante dos años el Instituto del Teatro de la Diputación Provincial, además ha sido Director, durante los cursos 1933-34, de la Sección Dramática del Conservatorio del Liceo, es asesor literario de las falanges teatrales del Sindicato Español Universitario. (Es Militante de FET y de las JONS). ${ }^{49}$

Vidal Nunell (1881-1965) ${ }^{50}$ va presentar una Memoria-Proyecto de reorganización del Instituto del Teatro de la Excma. Diputación Provincial de Barcelona, que no he localitzat en la documentació conservada a l'Arxiu General de la Diputació de Barcelona. ${ }^{51}$ Els mèrits personals que allegava

49 Ibídem. Les dades de matrícula reportades eren les següents: en el curs 1934-1935 es van matricular 12 alumnes a Declamació i 27 a Escenografia. En el curs 1935-1936, 19 alumnes es van matricular a Declamació i 33 a Escenografia. En el primer curs de postguerra es van matricular 29 a Declamació i 46 a Escenografia, i en el curs 1940-1941, 53 alumnes van triar Declamació i 31 Escenografia, segons les dades certificades per P. Bohigas Tarragó, secretari del centre. Com a contrapunt, al final del període que analitzo en aquest article, en el curs 1951-1952 es van matricular 52 alumnes a Declamació, 24 a Escenografia i 63 a Dansa. Ramón Picó Capdevila, Memoria del curso 1951-52 (Barcelona: Instituto del Teatro. Diputación Provincial de Barcelona. Escuela Superior de Arte Dramático, 1952), 6.

50 El 1940, Vidal Nunell havia presentat una instància perquè el nomenessin «profesor de canto de este Instituto del Teatro», que va ser desestimada per Díaz-Plaja el 4 de setembre en els següents termes: «Esta Dirección hace constar que las enseñanzas de teatro lírico y musical se hallan desglosadas de este Instituto, no habiendo por tanto posibilidad de acceder a lo que se solicita», A-96/1, AAH.

51 La presentació d'una memòria no era un requisit previ, només es preveia com a mecanisme per al cas d'empat entre els candidats, la qual cosa no es va arribar a produir en aquest cas. Vegeu supra nota 40. 
Vidal Nunell eren importants, però no s'ajustaven gens al perfil docent específic de l'Institut del Teatre: president de la Federación Española de Maestros Directores de Orquesta y Pianistas, i professor de cant i de solfeig al Conservatori de Música de Barcelona. ${ }^{52}$ Assenyalava també la seva condició de president de la Comisión Gestora del Montepío de Maestros Directores Concertadores de Barcelona, segons la còpia d'un ofici del Ministerio de Organización y Acción Sindical del 5 de juny de 1939, i aportava, a més: $a$ ) una altra còpia d'un ofici del «Sindicato $N^{0} X X$. Sección Teatro, Sub-Sección de Maestros Directores de Orquesta, nombrándole en $1^{\circ}$ de junio de 1939 asesor de la Secretaría, en ausencia de su titular»; $b$ ) un ofici de la Junta Directiva de l'«Asociación Musical de Barcelona, nombrándole en 3 de julio de 1908, Director del Orfeón», i c) un número de la Gaceta Musical «con un artículo de "Historial del Teatro Lírico Práctico Nacional"».53

El director i actor Gimbernat (1875-1951), que s'havia postulat com a director l'octubre de $1939,{ }^{54}$ anotava la seva condició de batxiller i aportava dos avals. En relació amb els seus mèrits personals, allegava la seva condició de «publicista», de membre de la Sociedad de Autores, de director de «la Escuela de Declamación del Círculo Artístico de Barcelona, el 2 de marzo de 1935» i de «llevar treinta años de profesional, actuando en los teatros y Coliseos de más responsabilidad de España: Teatro Español y Comedia de Madrid y el Poliorama, Romea y Novedades de Barcelona».55 Quant a Lope de Castro y Fernández de Alvarado, llicenciat en Dret, aportava un certificat del Collegi d'Advocats de Barcelona, en què s'assenyalava «haber sido depurado sin sanción», una relació «de vicisitudes personales sufridas en período rojo», i una còpia del «carnet de la FET y de las

52 Vidal Nunell era conegut també com a creador del Teatre Líric Pràctic, l'objectiu del qual era aconseguir que els alumnes que es dedicaven a l'estudi de l'art líric fessin pràctiques escèniques per adquirir una millor desimboltura en els seus moviments. Durant la dictadura de Primo de Rivera li va ser atorgada la Medalla del Treball. Vegeu l'entrada a la Viquipèdia, https://ca.wikipedia.org/ wiki/Joaquim_Vidal_Nunell (consultat el 16 d'octubre de 2015). Quant al Conservatori de Música de Barcelona, vegeu Xosé AviñoA, Cent anys de Conservatori (Barcelona: Ajuntament de Barcelona, 1986).

53 Q-569/48, AGDB.

54 Vegeu supra notes 19 i 27. Gimbernat havia presentat la dimissió com a professor auxiliar l'octubre de 1941.

55 Q-569/48, AGDB. 
JONS». No aportava, en canvi, cap tipus de documentació relacionada ambles activitats i els ensenyaments que s'impartien a l'Institut del Teatre.

Porta Sarret es presentava com a «practicante de Medicina y Cirugía, Secretario Judicial y de Ayuntamiento, Diplomado en Filosofía y en Ciencias político-sociales por la Universidad de Bélgica», amb carnet de periodista «expedido por el Ministerio de la Gobernación», i una còpia del carnet de militant de FET y de las JONS. Aportava un «programa de clases nocturnas gratuitas de la Obra Nacional Educación y Descanso, en el que consta que tiene a su cargo las asignaturas de Declamación, Literatura y Periodismo». En l'apartat dels seus mèrits personals, destacava el càrrec de «Delegado Provincial del Departamento de la Obra Nacional "Educación y Descanso" desde la fundación hasta la anulación del Departamento», haver estat professor «de Declamación y Literatura en la Escuela Nocturna de Bellas Artes de la Obra Nacional Educación y Descanso», i haver «cultivado la enseñanza del canto» sense més especificació. Feia gala de la seva «personalidad artística» reconeguda públicament per músics, poetes i editors, sense cap explicitació, i d'haver obtingut «premios literarios en los Juegos Florales Tradicionalistas celebrados en el Palacio de la Música en 1928».56

Junyent (1901-1982), llicenciat en Dret, feia constar la seva condició de «Juez Municipal Suplente del Juzgado $\mathrm{n}^{\circ} 6$ de Barcelona» i una còpia del seu nomenament com a secretari provincial d'«Educación Nacional, de FET y de las JONS». En l'apartat dels mèrits personals, s'anotava el següent:

Que a parte de sus actividades políticas desempeña el cargo de redactor de plantilla y crítico teatral de El Correo Catalán desde el año 1925 y aduce como hecho probatorio de su competencia, en disciplinas teatrales, la conferencia que pronunció en la Asociación de Santo Tomás de Aquino en diciembre de 1940, sobre el tema «Los temas religiosos en el Teatro Clásico Español». Durante la larga etapa en que viene ejerciendo de crítico teatral, se ha visto hon-

56 En relació amb la posició que va adoptar durant la Dictadura de Primo de Rivera es pot consultar el seu opuscle Dictadura? No. Regeneración: folleto histórico, filosófico, descriptivo del momento actual (Barcelona: Publicaciones Mir y Jorba, 1923). 
rado con gran número de comunicaciones en las cuales figuran las firmas de Benavente, Linares Rivas, los hermanos Quintero, Marquina, Pemán, Góngora, etc., y como consecuencia de su incesante batallar en la prensa, en la tribuna y por todos los medios a su alcance, por España y por la Religión, sufrió encarnizada persecución durante la ominosa época anarco-separatista, siendo juzgado por el Tribunal Popular $n^{\circ}$, tras seis meses de cautiverio en la Torre de la Muerte de la Bonanova, Cheva [sic] de San Elias y calabozos de Jefatura y Palacio de Justicia. ${ }^{57}$

Quant a Moragas Roger (1902-1970), un llicenciat en Dret que exercia la crítica teatral al Diario de Barcelona i era també autor teatral, no consta que hagués aportat cap mena de documentació..$^{8}$

\section{Director «en propiedad» de l'Institut del Teatre}

El tribunal no va trigar gaire a prendre una decisió sobre el concurs, segons consta en l'acta de la reunió celebrada el 4 de juliol en el palau de «la Excma. Diputación Provincial de Barcelona»:

Previo un cambio de impresiones, acordose por los reunidos proceder por eliminación, es decir, excluir a aquellos concursantes que, ya por falta evidente de méritos, ya por no haber presentado la oportuna documentación, no existía la menor duda respecto a sus aptitudes y condiciones requeridas para ocupar en propiedad, quedando para examen y estudio los concursantes señores Don José $M^{\mathrm{a}}$ Junyent y Don Guillermo Díaz Plaja.

El Tribunal después de examinar con detención los documentos acompañados por ambos concursantes y los méritos alegados por los mismos, acuerda, por unanimidad, elevar a la Comisión Gestora de la Diputación Pro-

57 Q-569/48, AGDB.

58 Era autor de La culpable (1935), La jaula (1940), Mañana, el amor (1941) i Gastos secretos (1942). Va escriure també amb Lluís Elias Romeu: de 5 a 9 (1957), que Joan Capri va estrenar al Teatre Romea. Un any abans de la convocatòria del concurs, el 30 de maig de 1940 va ser convidat a fer una conferència a l'Institut del Teatre sobre «Los niños y el teatro». 
vincial la propuesta de nombramiento de Director del Instituto del Teatro al concursante Don Guillermo Díaz Plaja. ${ }^{9}$

Com el lector ha pogut copsar, les bases específiques del concurs oposició s'havien fixat d'una manera molt favorable a la candidatura de DíazPlaja. Entre els altres concursants, n'hi havia que no aportaven cap mena de documentació relacionada amb el món teatral (Amat, Lope de Castro y Fernández Alvarado); el candidat Vidal Nunell hi contribuïa amb un perfil docent de l'àmbit musical i una activitat paraprofessional relacionada amb l'òpera. Els altres candidats avalaven algun tipus de vincle amb el teatre, en l'àmbit docent (Porta Sarret), en el de la interpretació i la direcció (Gimbernat), o en el de la crítica i l'autoria dramàtica (Junyent i Moragas).

Altrament, Díaz-Plaja reunia amb escreix els «méritos especiales» expressats en les bases del concurs, i feia a més dos anys que dirigia interinament l'antiga Escola Catalana d'Art Dramàtic. Com reconeixia ell mateix en la sollicitud signada l'1 de juny de 1941 per participar en el concurs oposició, estava en "posesión de todas las condiciones previstas para tomar parte en él, y, al mismo tiempo, [...] posee de manera evidente y extraordinaria la totalidad de los méritos especiales que en las bases del concurso se anuncian». ${ }^{60}$

En la documentació que es conserva s'hi compten, com ja he assenyalat més amunt, dos avals i tres certificats. Els avals, d'un caràcter polític innegable, corresponents a Juan Ramón Masoliver i Luys Santa Marina, duien les dates del 6 i el 14 d'octubre de 1939 respectivament. Aportava també el certificat signat el 14 de juliol de 1939 per Fernando Valls y Taberner, president del tribunal, que l'havia incorporat a la direcció de la

59 Q-569/48, AGDB. En l'acord del 8 de juliol que el delegat ponent de Cultura va elevar a la Comissió Gestora de la Diputació, es feia referència «al haber anual de nueve mil pesetas (9.0oo)», una quantitat que va ser revocada per l'interventor de l'organisme provincial: «toda vez que el presupuesto vigente, en la subpartida I del anexo $\mathrm{n}^{\circ} \mathrm{XIV}$ correspondiente a los gastos de personal del expresado Instituto del Teatro fija para las funciones de Director el haber anual de 6.ooo pesetas, y siendo las consignaciones del presupuesto provincial obligatoriamente limitativas, y teniendo además en cuenta que las disposiciones vigentes preceptúan que no ha de efectuarse, en el actual ejercicio, ampliación en los servicios, con arreglo a aquella consignación debió formularse la convocatoria el concurso correspondiente». Posteriorment, el 5 de juny de 1942, consta que li va ser assignada la retribució de 9.000 pessetes anuals (vegeu Q-571, AGDB).

6o Ibídem. Els destacats són seus. 
Secció de Declamació del Conservatori del Liceu el 1933. El certificat del secretari de l'Institut Jaume Balmes, datat el 26 de maig de 1941, manifestava que Díaz-Plaja «reincorporado al ejercicio de su cátedra inmediatamente después de la entrada de las tropas nacionales, ha sido definitivamente confirmado en su cargo, previos los obligados trámites de las correspondientes Comisiones depuradoras, hallándose por lo tanto en la plenitud de sus derechos civiles y profesionales». El darrer aval, datat el 30 de juny de 1941, era signat per Jorge Vila Fradera, cap del Departament de Premsa, Propaganda i Relacions del Districte universitari de Catalunya i Balears, amb el vistiplau d’Andrés Rodríguez Villa, cap del Districte Universitari de Catalunya i Balears:

Desde el comienzo de la actuación de estas falanges de teatro universitario de nuestra organización, D. Guillermo Díaz-Plaja no sólo nos ha prestado su incondicional ayuda y consejo, si no que, además, ha tomado parte muy activa en nuestras tareas. Ha presentado a nuestros camaradas en numerosas representaciones llevadas a cabo en Barcelona y otras poblaciones desde que la citada Sección de Teatro Español Universitario inició su labor en octubre de 1939, dirigiendo la palabra al público para subrayar el esfuerzo que nuestra obra representaba; ha facilitado en todo momento cuantos elementos han estado a su alcance para resolver los naturales problemas de organización; en suma: ha puesto todo su entusiasmo falangista y todos sus conocimientos técnicos y literarios al servicio de este aspecto de la labor del Sindicato Español Universitario, vanguardia cultural de nuestro Movimiento.

Teniendo noticia, por la prensa, de que por prescripción reglamentaria va a ser provista la plaza de Director del Instituto del Teatro de esa Excma. Diputación Provincial, mediante Concurso-oposición; este Departamento, de manera espontánea, se ha sentido en el deber de informarle de la complacencia y gratitud del mismo por la labor desarrollada por D. Guillermo Díaz-Plaja con referencia a este aspecto de nuestras actividades artístico-teatrales.

Por Dios, por España y su Revolución Nacionalsindicalista. ${ }^{61}$

61 Ibídem. Sobre el TEU, vegeu Manuel AzNar SOLER, «El teatro universitario en Barcelona durante el franquismo (1939-1975)», dins Luciano García Lorenzo, ed., Aproximación al teatro español universitario (TEU), Anejos de Revista de Literatura 46 (Madrid: CSIC, 1999). 
Era tal vegada la cirereta que li faltava per captar la família falangista i el món teatral, a més de proporcionar-li un vincle circumstancial amb la universitat. Certament, l'únic contrincant amb pes pròpiament polític amb què s'enfrontava Díaz-Plaja en el concurs era J. $\mathrm{M}^{\mathrm{a}}$ Junyent Quintana, ${ }^{62}$ fill de Miquel Junyent Rovira, un dels caps de la Comunió Tradicionalista i director d'El Correo Catalán durant trenta anys, que havia mort poc abans que anessin a trobar-lo a casa seva en l'inici de la revolució de juliol de $1936{ }^{63}$ Una germana seva, Montserrat Junyent Quintana, estava casada amb Joan B. Roca Caball, ${ }^{64}$ que, procedent del camp tradicionalista, havia estat un dels fundadors d'Unió Democràtica de Catalunya (1931) i s'havia exiliat a França a finals de 1936, d'on va tornar el 1940. En els primers anys quaranta, Junyent Quintana encarnava públicament l'ideari tradicionalista en matèria cultural, als antípodes de les posicions del sector falangista.

Un cop designat Díaz-Plaja com a director de l'Institut del Teatre, es va produir un incident amb Junyent que revela, si més no, certa rivalitat personal i política entre ells dos. Arran d'una adaptació teatral de Madame Butterfly de Puccini, i interpretada per Maria Joana Ribes, una alumna de l'Institut del Teatre, Junyent va publicar una ressenya en què qüestionava la implicació de l'Institut en l'organització del muntatge:

El sábado por la noche se representó en el Teatro Studium la adaptación teatral de la obra de Puccini, Madame Butterfly, comedia que nunca lograron poner a flote discretas compañías por la pobreza literaria de su diálogo y la ramplonería de sus situaciones dramáticas. De ahí que nos sorprendiera el que María Juana Ribes protagonizara la tontaina «Mariposa» que se cae de

62 Segons Joan M. Thomàs: «També es trobava a prop de FET, el fill de Miquel Junyent, José María Junyent Quintana, Cap de FET de Piera (d’on era la seva família) i jutge municipal per designació. Junyent fou dels assistents al funeral del "Día de los mártires de la Tradición”", Falange, Guerra Civil, Franquisme. FET y de las JONS de Barcelona en els primers anys del franquisme, Biblioteca Abat Oliba 116 (Barcelona: Publicacions de l'Abadia de Montserrat, 1992), 369.

63 «Una muchedumbre entró en casa del principal carlista catalán, Miguel Junyent, que moría de un ataque cardíaco antes de ser fusilado, mientras que el antiguo diputado Casimiro Sangenís fue ejecutado tras un simulacro de proceso", Martin Blinkhorn, Carlismo y contrarevolución en España 1931-1939, Temas Hispánicos 54 (Barcelona: Editorial Crítica, 1979), 361.

64 Vegeu la biografia de Ferran Camps \& Joaquim Monclús, Joan Baptista Roca i Caball (18981976). Impulsor de la pau civil (Barcelona: Proa, 1998). 
cursi y nos extrañara aun más —y con pena lo confesamos - que el Instituto del Teatro —organismo oficial de la Excma. Diputación — apoyara y sellara con su cuño la propaganda de la predicha representación, no por lo que tiene de mala la comedia, sino por el hecho de que se consignara en los programas con todas sus letras y los apellidos de dos insolventes escritores, uno de ellos el máximo blasfemo de la Soli anarquista durante la guerra española. Creíamos - en verdad- que firmas de tal jaez no asomarían nunca más por los impresos de la España liberada. La interpretación y la puesta en escena no pasó de discreta. ${ }^{65}$

Un apunt necessari: la representació va tenir un caràcter únic. ${ }^{66}$ L'enrabiada de Díaz-Plaja va ser colossal i fa pensar que l'incident no devia ser casual, sinó més aviat una topada més de les que es devien produir entre el personal afecte a les distintes famílies polítiques del règim en els primers anys de la seva implantació. ${ }^{67}$ L'endemà mateix de l'article de Junyent, Díaz-Plaja va enviar una carta flamejant al president de la Asociación de la Prensa en què feia referència a la «derrota» de Junyent en el concurs oposició. Segons explica, la mateixa Diputació de Barcelona «ha dado cuenta ya a la autoridad gubernativa de este asunto y ella decidirá la sanción que debe imponerse a quien olvidando su condición de servidor de una causa de disciplina y unificación se permite tan insólitas manifestaciones». I concloïa:

Pero hay un aspecto fundamental de esta cuestión que afecta a su honorabilidad y de rechazo a la mía lo que estimo urgente poner en su conocimeinto.

65 «Studium. Madame Butterfly», El Correo Catalán, 25 nov. 1941: 5.

66 «En el Studium. Mañana, a las diez de la noche, se celebrará en el Teatro Studium (Bailén, 72) un selecto festival de arte, en el cual se representará la leyenda japonesa, en tres actos, Madame Butterfly, por María Juana Ribas», La Vanguardia Española, 22 nov. 1941, 7.

67 Segons Joan M. Тнома̀s: «Així, després d'uns anys de marginació del "staff” de la FET —el 1939 i el 1940-, quan el 1941, el governador civil i cap provincial del Movimiento Antonio F. de Correa Veglison obrí les portes de la direcció falangista a alguns carlins, aquests acceptaren càrrecs. Els mateixos, en bona part, serien els que collaborarien en l'operació carlococtavista el 1943", «El carlisme a Barcelona, el 1939", dins El carlisme com a conflicte (Barcelona: Columna, 1996), 310. Vegeu també del mateіх Тнома̀s, «Falangistes i carlins catalans a la "zona nacional" durant la Guerra Civil (1936-1939)», Recerques 31 (1995): 7-18. 
$1^{\circ}$.- Que el Sr. Junyent ha procedido con una mala fé indigna de un periodista honrado atribuyendo al Instituto del Teatro de la Excma. Diputación Provincial el patrocinio de una representación teatral absolutamente desligada de las tareas de este Instituto. Ni los programas ni los anuncios han hecho constar la menor intervención del Instituto en la aludida representación, que de haber existido hubiera sido subrayada en dicha propaganda.

$2^{\circ}$.- Que es posible que algún alumno del Instituto del Teatro haya solicitado y obtenido el membrete del mismo con la única finalidad de facilitar la publicación de las gacetillas anunciadoras de dicha representación, como se viene haciendo en cuantos elementos jóvenes desean llevar a cabo sus anhelos de dedicación al teatro; bien entendido que ello no implica naturalmente patrocinio alguno ni literario ni político, teniendo en cuenta sobre todo que la aprobación de los programas desde este último punto de vista corre a cargo exclusivamente de la Jefatura de Propaganda.

$3^{\circ}$.- Que el Sr. Junyent ha llevado su bajeza hasta el extremo de involucrar una institución oficial al rencor que siente hacía mi por el sencillo hecho de haber sido derrotado en el concurso oposición para la dirección del Instituto del Teatro cuando tuvo la audaz idea de enfrentar su personalidad con la que muchos años de estudio, la publicación de 30 libros y la obtención de triunfos académicos me ha procurado. Como periodista español protesto de que este Sr. pueda continuar firmando sus rencorosos abruptos.

En espera de una rectificación de justicia y de una decisión que deje a salvo mi honorabilidad queda de Vd., atento s. s. ${ }^{68}$

68 Q-444/130, AGDB. Posteriorment, Maria-Joana Ribas, premi extraordinari Enric Giménez de declamació (curs 1941-1942), va rebre un homenatge el 16 de febrer de 1945 al FAD (Foment de les Arts Decoratives) amb un Comitè d'Honor presidit per l'actor Enric Borràs i constituït per José Bonet del Río (President del Círculo Artístico), José $\mathrm{M}^{\mathrm{a}}$ Castro Calvo (degà de la Facultat de Filosofia i Lletres), G. Díaz-Plaja, Adrià Gual de Sojo (FAD), Luis Monreal (comisario de Defensa del Patrimonio Artístico de la Región de Levante), José Pardo i Jaime Palencia «por la Vicesecretaría de Educación Popular (Delegación Provincial de Barcelona)», Diego Ramírez Pastor (diputat provincial i president de l'Asociación de la Prensa de Barcelona), Santiago Rodoreda («Artista-Dibujante») i Luys Santa Marina (president de l’Ateneu Barcelonès). L'escriptor Tomàs Roig i Llop feia les funcions de secretari. L'acte, presentat per Díaz-Plaja, va constar d'un recital de poesies a càrrec de Maria-Joana Ribas i de la participació d'altres exalumnes de l'Institut del Teatre: Assumpció Balaguer, Montserrat Casas, Bartomeu Olsina i Lluís Tarrau. Com a colofó, Maria-Joana Ribas i Enric Borràs van oferir un diàleg d'El alcalde de Zalamea. Vegeu Arxiu Díaz-Plaja, Institut del Teatre, RABLB. 
No em consta que la «sanción» que Díaz-Plaja demanava per a Junyent fos duta a terme, si més no d'una manera pública i oficial. ${ }^{69}$

\section{Activitats i manifestacions realitzades fins al curs 1944-1945}

Les inauguracions de curs, les conferències i els tallers endegats pels alumnes constaten el tacticisme polític seguit per Díaz-Plaja durant aquesta etapa. ${ }^{70} \mathrm{Si}$ es fa el seguiment de les activitats recopilades pel secretari, P. Bohigas Tarragó, es pot copsar perfectament. Comencem per les inauguracions de curs, en què s'observa un cert eclecticisme en relació amb la tria dels conferenciants i els temes exposats. Com a norma, el nou director va convidar persones clarament identificades amb la situació política per raons d'amistat, de deute, també de reconeixement o interès cultural o artístic. Repassem-les: José Bonet del Río — «Evolución de la escenografía a la escenificación»(1939-1940)—; Joaquín de Entrambasaguas — «La valoración nacional del teatro español» (1940-1941)—; Jacinto Benavente — «Edipo, Hamlet y Segismundo» (1941-1942)—, que va ser l'excepció de la norma perquè després d'estrenar Aves y pájaros a Barcelona va ser redimit pel govern de la seva posició «republicana» durant la guerra; ${ }^{71}$ el falangista i acadèmic Eugenio Montes — «Teatro y sociedad»(1942-1943)—, i el seu mestre Eugenio d'Ors — «La virgen en Elche y el Diablo en Lucerna» (1943-1944). El mateix Díaz-Plaja va ser l'encarregat de la lliçó inaugural del curs 1944-1945 sobre «Geografía e historia del mito de Don Juan», un discurs farcit de referències erudites sobre la incidència del mite en una sèrie de tradicions literàries, sobretot l'espa-

69 Uns quants anys més tard, el 30 de gener de 1947, Junyent va ser convidat a fer una conferència sobre «La crítica teatral en su doble aspecto ético y crítico», dins P. BoHIGAS TARRAGó, Memoria del curso 1946-1947 (Barcelona: Instituto del Teatro. Diputación Provincial de Barcelona. Conservatorio Superior de Barcelona, 1947), 8.

70 En els primers anys va fer difusió de la institució en la premsa espanyola i estrangera del moment. Vegeu l'entrevista de F. S. I., «Una institución ejemplar. El Instituto del Teatro de Barcelona», Arriba, 5 juny 1943, 5, i Carlo TAMBERLANI, «L'Istituto del Teatro di Barcelona. Il teatro spagnuolo e la formazione dei seuoi attori», Giornale dello Spettacolo xvi (30 juny 1943): 3, dipositats a l'Arxiu DíazPlaja, RABLB. Es pot consultar també l'article «Das Theaterinstitut in Barcelona», Ibero-Amerikanische Rundschau (9 nov. 1942): 129-132 (A-70/5, AAH).

71 Vegeu Enric GalléN, El teatre a la ciutat de Barcelona..., 82-86. 
nyola, en què apareixien unes línies dedicades a la llegenda del Comte Arnau segons la versió de Joan Maragall i amb citacions en català. ${ }^{72}$

Parallelament, es van dictar algunes conferències sobre teatre alemany i teatre italià entre 1940 i 1944, i una sobre teatre francès (19441945). Es van impartir també conferències a càrrec d'escriptors, periodistes i professionals diversos de la cultura catalana i espanyola d'aquell temps: curs 1940 (Lluís Masriera, Josep F. Ràfols, Valentí Moragas Roger), curs 1940-1941 (Joaquín Montaner, Ángel Valbuena, F. Pérez-Dolz, Luis G. Manegat), curs 1941-1942 (Ángel Zúñiga, Eduardo Marquina, Eugenio Frutos, Huberto Pérez de la Ossa), curs 1942-1943 (Dámaso Alonso, Paco Melgares, Joan Givanel Mas, Adela Carbone, Luciano de Taxonera, Josep Mestres Cabanes), curs 1943-1944 (Bartomeu Olsina, Enric Guitart, Gerardo Diego, Ramon Planas) i curs 1944-1945 (Cayetano Luca de Tena, Lola Membrives).

En l'àmbit de les representacions i activitats pedagògiques dels alumnes es van realitzar tallers amb escenes o fragments del teatre romàntic espanyol; la trilogia Lo invisible d'Azorín (1940) i La reja dels germans Quintero; el teatre del Segle d'Or; En Flandes se ha puesto el sol (19401941) i altres textos de Marquina (1941-1942); El alcalde de Zalamea amb Enric Borràs al Teatre Barcelona (11-2-1943); obres clàssiques espanyoles sobre Nadal (1943-1944) i, especialment, la representació d'El gran Teatro del Mundo en el marc del Congreso Eucarístico Diocesano; ${ }^{73}$ escenes de Lope, Benavente, Tamayo y Baus (1944-1945). De manera excepcional, per commemorar les exposicions barcelonines de 1888 i 1929, es va oferir al Teatre Barcelona la representació d'un acte de Batalla de reines, de Frederic Soler, premi Fastenrath de la Real Academia Española de la Lengua, que s'havia representat davant de la Regent Maria Cristina

72 «Es extraño que nadie haya reparado en el precedente que representa la antigua leyenda de $E l$ Comte Arnau, poetizada por Juan Maragall. [...] Como coincidencia última, cuando al final del ciclo poemático surge, como una redención del atormentado héroe, es una sublimación del ideal femenino la que produce el milagro: Lo que la mort tanca i captiva, | sols per la vida és deslliurat: | basta una noia amb la veu viva | per redimir la humanitat.», Geografia e historia del mito de Don Juan: discurso pronunciado por el Director del Instituto del Teatro Dr. D. Guillermo Díaz-Plaja en el acto inaugural del curso 1944-1945, Discursos 1 (Barcelona: Instituto del Teatro. Diputación Provincial de Barcelona. Conservatorio Superior de Declamación y Danza y Escuela de Escenografía, 1945), 17-18.

73 «El Gran Teatro del Mundo», dins BohIGas, Memoria del curso 1943-44, 9. 
el 1888. Per a la funció celebrada el 13 de maig de 1945, es va utilitzar la traducció espanyola de Melcior de Palau. Com a compensació menor, el 27 de maig els alumnes van representar, en el marc de l'Institut, algunes escenes de Don Joan, una obra inèdita de Gual, en una mena d'homenatge pòstum i privat.

En l'àmbit de les ressenyes necrològiques sobre personatges de la vida teatral catalana, la manca generalitzada de referències explícites i detallades als vincles de la majoria dels desapareguts amb el teatre català són a l'ordre del dia. En faig la relació: els vinculats a la institució com Enric Giménez (1939), Salvador Alarma (1941), August Barbosa (1941), Adrià Gual74 i Joaquim Pena; l'actor i director Alexandre Nolla (1943); els crítics Emili Tintorer i Manuel Rodríguez Codolá; l'escenògraf Joan Morales; els escriptors Lluís Millà, D. Coromines Prats, i l'actor Joaquim Vinyes (1944-1945).

\section{Creació del Conservatori Superior de Música i Declamació de Barcelona (1944)}

Segons el decret del Ministerio de Educación Nacional, datat el 26 de gener de 1944, es creava el Conservatori Superior de Música i Declamació de Barcelona, constituït pel Conservatori del Liceu, l'Escola Municipal de Música i l'Institut del Teatre, tot fusionant les tres institucions oficials d'ensenyament artístic de Barcelona en una sola entitat.75 En certa manera, culminava una de les preocupacions i desitjos de Díaz-Plaja, com revela la carta i l'informe adjunt ${ }^{76}$ que va trametre a Juan de Contreras y

74 Ibídem, 10.

75 Vegeu l'annex 6.

76 L'Informe sobre el Instituto del Teatro de la Excma. Diputación Provincial de Barcelona, de dos fulls i escaig d'extensió, tractava de la «Finalidad y alcance de la Institución», «Situación, instalación», «Tradición», «Personal», «Estudios que se realizan», «Finalidad práctica», «Prestigio de la institución» $\mathrm{i}$ «Necesidades del Estado con respecto a Barcelona». D’aquest darrer epígraf paga la pena transcriure'n el seu contingut: «Como se ve por las notas anteriores, el Instituto del Teatro llena completamente y sobrepasa en muchos aspectos la misión que el Estado asigna a los conservatorios de Declamación y posee y goza de la gran consideración de los medios intelectuales y políticos. Téngase en cuenta que a pesar de la importancia cuantitativa y cualitativa que Barcelona tiene, el Estado no ha creado allí ningún conservatorio oficial y es evidente que la Diputación Provincial de Barcelona con tenacidad y entusiasmo dignos de toda loa ha superado esta deficiencia. Teniendo en cuenta, sin 


\section{López de Ayala, marqués de Lozoya, director general de Bellas Artes, el 29 de setembre de 1942:}

Por noticias que circulan con insistencia por aquí parece próxima la reordenación de los Conservatorios de Declamación que dependen de la Dirección General de Bellas Artes; dicha reorganización iría acompañada lógicamente de la creación de dichos servicios docentes en Barcelona y en cuantas partes se creyese necesario. Con ello culmina una tarea personal - la de V.que sólo plácemes entusiastas merece de cuanto nos interesamos por estas cuestiones.

Pero es un imperioso deber mío recordarle en este momento la existencia de nuestro Instituto del Teatro, que $V$ [paraula illegible] visitándolo en uno de sus viajes a Barcelona. El Instituto del Teatro cuenta veintisiete años de existencia; su espléndida vitalidad pueden atestiguarla las cifras últimas de Secretaria: Ochenta y seis inscripciones de ingreso. El Instituto del Teatro ha sido reincorporado - después de liberarse Barcelona- al sano espíritu nacional. El Instituto del Teatro es, como verá en el folleto adjunto, algo más amplio que un Conservatorio de Declamación, contiene un conservatorio de escenografía, una biblioteca especializada abierta al público y un museo y archivo teatral.

embargo, el proceso de coordinación de este servicio que la Dirección General está empezando a llevar a cabo nosotros creemos que el Instituto del Teatro, por lo menos en su sección de Declamación, podría integrarse en la sección general de organismos estatales dedicados a la enseñanza de Declamación. Pero por otra parte si se tiene en cuenta la novedad y la vitalidad de sus procedimientos docentes la amplitud de sus secciones y la complicidad de sus servicios no es aconsejable proceder con un criterio meramente uniformista que corriere el peligro de comprometer la vida espiritual de este centro. Pero por otra parte tampoco es aconsejable en manera alguna que el Estado pueda de algún modo prescindir de este Instituto, lleno de prestigio y de realizaciones prácticas para crear un organismo similar al que se concediese únicamente el favor del Estado y que plantease los consabidos problemas de rivalidad, competencia y en último término dispersión de esfuerzos. La solución podría ser análoga a la que el Estado ha adoptado con respecto a la Junta de Museos de Barcelona organismo surgido de las instituciones locales y sostenido por ellas. El Estado delega su representación en el Director del Instituto, aprueba las orientaciones generales de su organización, concede validez oficial a sus estudios análogos, a la de los conservatorios y finalmente subvenciona con una cantidad que siempre sería menor que el presupuesto habitual de instalación y mantenimiento de un conservatorio. De este modo quedaría salvado el prestigio del Estado, coordinados y dotados de sentido nacional unos servicios ya existentes, resuelto favorablemente por el Estado el problema económico que estos organismos planteen y por otra parte quedaría salvada una institución digna de toda clase de estímulos y de respetos». Arxiu Díaz-Plaja, Institut del Teatre, RABLB. 
Aquí todos estamos seguros de que el Estado reconocerá nuestra existencia. No hay, por nuestra parte, resquemor alguno hacia lo estatal; por el contrario, nos complacería vivamente asumir en Barcelona la tarea que el Estado asigna a los conservatorios de las demás ciudades españolas. En realidad el contacto existe ya: el Teatro Escuela Lope de Rueda acaba de fundarse sobre la pauta de nuestro Instituto, del que la Diputación de Barcelona se siente verdaderamente orgullosa.

Las fórmulas no serían difíciles de hallar. Bastaría, por ejemplo - como se hizo con los museos en el caso de Javier de Salas - con considerar la Dirección del Instituto como Delegado del Estado para el cumplimiento de la misión que llevan a término los Conservatorios. Con ello, incluso, se facilitaba el problema económico pues el Estado en vez de correr con los gastos totales de instalación y nóminas podría limitarse a una subvención para mejora de los servicios en el momento en que se le asignaba categoría nacional.

En suma, querido Marqués, nosotros estamos convencidos de que V. hallará la fórmula justa. Y en el ínterin me es grato reiterarme de V. muy atto, s.s. q.e. s.m. ${ }^{77}$

L'esmentat decret assegurava el manteniment de la personalitat singular dels tres organismes. ${ }^{78}$ En el cas de l'Institut, els ensenyaments de Declamació van ser adaptats «al general de los Conservatorios del Estado» i es complementaven amb els de Dansa, amb un canvi significatiu en el pla

77 Arxiu Díaz-Plaja, Institut del Teatre, RABLB. La còpia de la carta mecanografiada presenta alguns fragments illegibles. Sobre la Junta de Museus, vegeu Luisa SALA i Tubert, La Junta de Museus i les exposicions de belles arts durant la postguerra, Textos d'Història i Cultura 7 (Barcelona: Fundació Carles Pi i Sunyer, 2010). Vegeu també Eulàlia Pérez Vallverdú, La política cultural municipal de l'etapa de l'alcalde Miquel Mateu i Pla (1939-1945). Aspectes generals, Textos d'Història i Cultura 8 (Barcelona: Fundació Carles Pi i Sunyer, 2010).

78 Vegeu l'annex 4. Per Graells: «La principal conseqüència d'aquesta creació fou que l'Institut hagué d'adaptar el seu pla d'ensenyament al d'altres conservatoris de l'Estat — fet que suposà, per fi, la creació de la Secció de dansa, deu anys després del primer intent - i alhora que es reconegués oficialment la validesa dels estudis i els títols, en una homologació que fou l'única en més de quaranta anys i que, tot i la seva insuficiència, ha estat la base sobre la qual ha recolzat l'oficialitat i el rang dels ensenyaments de l'Institut fins als nostres dies. Es tractava d'un esdeveniment essencial en la història del centre, però la fórmula ambigua adoptada i la múltiple dependència institucional —el Ministeri a nivell acadèmic, i la Diputació, l’Ajuntament i un Patronat com a suport real, administratiu i pressupostari- motivaren que el nou Conservatori no fos, en realitat, més que una denominació genèrica, sense existència efectiva més enllà de la tramitació burocràtica», L'Institut del Teatre..., 87. 
d'estudis. ${ }^{79}$ Proposat per la Diputació Provincial de Barcelona i el Ministerio de Educación Nacional, Díaz-Plaja, que havia desplegat una intensa activitat per aconseguir la creació del conservatori entre 1942 i $1944,{ }^{80}$ va ser nomenat secretari de la Junta del Conservatori (15 d'abril de 1944), mentre que Alfonso Sala Argemí, que va ser nomenat president de la Mancomunitat de Catalunya pel dictador Primo de Rivera el setembre de 1923, es va convertir en el delegat de l'Estat. ${ }^{81}$ Amb el decret, els ensenyaments de Declamació i Dansa «tienen el carácter oficial para toda España, así como los títulos acreditativos de las mismas». ${ }^{82}$

Una resolució posterior de la Dirección General de Bellas Artes (12 de juliol de 1946) va autoritzar que el Conservatori Superior de Barcelona concedís als alumnes que acabessin els estudis diplomes de capacitació semblants als que atorgava el Real Conservatorio de Madrid, i un decret del Ministeri una setmana després «donava entrada en el Consell Rector del Conservatori a les corporacions responsables dels centres que l'integraven» ${ }^{83} \mathrm{Al}$ cap de dos anys i mig, «el [25 de] febrer de 1949, una disposició ministerial oficialitzava la situació de fet referent a la validesa de títol per a l'obtenció del carnet sindical que fins aleshores s'aplicava per la decisió de la CNS gestionada per Díaz-Plaja». ${ }^{84}$

79 Segons l'Acord de la Comissió Gestora (6 oct. 1944), mitjançant un concurs restringit al professorat existent a l'Institut del Teatre, es van proveir les càtedres de Declamació Pràctica (Marta Grau), Escenografia (Josep Mestres Cabanes), Dibuix i Realitzacions Escèniques (Artur Carbonell), Indumentària i Arts Sumptuàries (Ramon Picó), Dansa (Joan Magrinyà), Auxiliar de Dicció i Lectura Expressiva (Bartomeu Olsina) i Auxiliar d'Acompanyant de Dansa (Concepció Pujol). El 18 de gener de 1945 es va crear per a Miquel Xirgu, germà de l'actriu, amb caràcter eventual, la càtedra de Caracterització Escènica, un «cargo que había quedado sin proveer en el concurso antes referido», Pere BoHigas TARRAGó, Memoria del curso 1944-45 (Barcelona: Instituto del Teatro. Diputación Provincial de Barcelona. Conservatorio Superior de Barcelona, 1945), 8-9. Com a ajudants de les classes de Dansa es van nomenar Filomena Feliu i María Blanco Estévez. Vegeu també Guillem-Jordi Graelis, L'Institut del Teatre..., 89-91.

8o Vegeu les memòries corresponents de l'entitat, especialment la del curs 1943-44.

81 Per motius de salut, Alfonso Sala Argemí (1863-1945) va dimitir, i Arturo Sedó Guixard (18811965) va assumir la delegació l'Estat l'1 de març de 1944. Cinc anys més tard, a partir del 24 de maig de 1949, Sedó va començar a demanar de manera reiterada per raons d'edat i de salut la seva substitució, que no li va ser acceptada fins al 1956. Vegeu els documents de dimissió dins el Fons Artur Sedó i Guixard, ms. 2160/1-7.6, Biblioteca de Catalunya.

82 Vegeu supra nota 75 .

83 Graells, L'Institut del Teatre..., 87.

84 Ibídem. 


\section{Activitats i manifestacions realitzades a partir del curs 1945-1946}

Les conseqüències del desenllaç de la Segona Guerra Mundial van generar una nova situació política, que va afectar l'organització de les institucions docents i culturals de titularitat pública. Díaz-Plaja va procurar adequar-s'hi i servir-se'n des del punt de vista institucional i personal. A partir del curs 1945-1946, un cop estabilitzada la plantilla bàsica de professors de l'Institut, ${ }^{85}$ els discursos d'inauguració de curs van anar a càrrec dels responsables de les càtedres de manera rotatòria. ${ }^{86}$

Si s'analitza aquesta etapa fins als primers cinquanta, un dels canvis significatius afecta la represa de les publicacions de la institució, discretament iniciada amb l'edició del discurs d'inauguració del curs 1944$1945^{87}$ i poc abans amb l'opuscle Esquema de Historia del Teatro (1944), tots dos obra de Díaz-Plaja. ${ }^{88}$ L'Esquema, que encetava la «tercera sèrie» dedicada als estudis, era una traducció de L'evolució del teatre, que havia constituït deu anys enrere el número 103 de la Collecció Popular Barcino, ${ }^{89}$ revisada i adaptada quant als continguts al nou context polític i

85 Arran de ser «requerida para otras actividades la ayudante de las clases de Danza, señorita María Blanco Estévez», va ser substituïda a «primeros de 1946» per María Gómez de Ávila (ibídem, 6). Posteriorment, el 6 d'octubre de 1948, Maria de Ávila hi va renunciar i va ser substituïda per Roser Contreras. En l'ordre de les defuncions, cal anotar la de Luis Calvo López, que va ser director de la institució durant l'anomenat Bienni Negre (entre el 17 de desembre de 1934 i el setembre de 1935), i la del crític i escriptor Lope F. Martínez de Ribera. Vegeu BohIgAs, Memoria del curso 1946-47, 11.

86 G. Díaz-Plaja, Geografia e historia del mito de Don Juan (curs 1944-1945); J. Mestres CabANES, El angulo maestro de la escenografia (1945-1946); Marta GRAU, Importancia y técnica de la Declamación (1946-1947); A. CARBONELL, Orientaciones de la escena europea contemporánea (19471948); J. MAGRINYÀ, Valores pedagógicos de la Danza (1948-1949); G. DíAz-PLAJA, Lo que ha sido y podría ser el Teatro de la Ciudad (1949-1950). En els dos últims cursos acadèmics d'aquesta etapa la rotació va donar pas a conferenciants convidats, aliens a la institució, com José Ma Pemán, Nuestro teatro, caso español (1950-1951), i A.G. BRAGAGLIA, Escenografía y escenotecnia (1951-1952).

87 Vegeu supra nota 72.

88 El número 2 de la collecció Estudios va anar a càrrec de Ramón Picó CaPdevila, que va publicar Resumen de Historia de la Indumentaria (Barcelona: Instituto del Teatro. Diputación Provincial de Barcelona, 1945).

89 Díaz-Plaja hi constava com a «Director de la Secció d’Art Dramàtic del Conservatori del Liceu». Com a resultat de la seva vinculació amb el Conservatori del Liceu, el 1939 va decidir publicar les tres conferències sobre temes de la història del teatre — «El personaje inexistente», «El protagonista y su criado", «Acción y Escenografía»-, que havia dictat els dies 3, 8 i 17 de novembre de 1932, respectivament, un any abans d'assumir la direcció de la secció. Vegeu «El teatro y sus personajes», dins La ventana de papel (ensayos sobre el fenómeno literario), Colección de Ensayistas Españolas 1, (Barcelona: Editorial Apolo, 1939), 91-115. Posteriorment, les va tornar a editar sense modificacions, 
amb més relleu del teatre espanyol. El llibret contenia un capítol final que ja no era dedicat a «El teatre romàntic i el contemporani», sinó estrictament a «El siglo XIX», en què destacava, per aquest ordre, Victor Hugo, Richard Wagner i «El teatro romántico en España», amb una petita referència a La conjuración de Venecia de Martínez de la Rosa; Don Álvaro o la fuerza del sino del Duque de Rivas; El trovador de García Gutiérrez, i Los amantes de Teruel de Hartzenbusch i Zorrilla, amb què es cloïa l'estudi. Desapareixia també de manera significativa la dedicatòria de la versió en català del llibre al «Dr. Àngel Valbuena i Prat».

D’altra banda, Díaz-Plaja va obrir una nova sèrie amb el títol «Investigaciones», en què es van publicar contribucions relacionades amb una realitat cultural específicament barcelonina o catalana: el que Josep Artís va dedicar al coreògraf Ricardo Moragas. Prioridad de su arte. La vida y la obra (1946), i el de P. Bohigas Tarragó sobre Las compañias dramáticas extranjeras en Barcelona (1948).

En l'àmbit de les conferències podem destacar les de Nicolás González Ruiz sobre «Las adaptaciones de Shakespeare» (curs 1945-1946); Walter Starkie, delegat del British Council, sobre «W.B. Yeats y el teatro irlandés» (curs 1947-1948); Ramon Planes sobre «La angustia en el teatro francés contemporáneo» (curs 1948-1949); la del mateix Díaz-Plaja sobre «Últimas novedades de la escena europea» (curs 1948-1949), ${ }^{90}$ o la d'Arnold Lionel Haskell, director de l'escola de ballet Sadler's Wells de Londres, sobre «La naissance du théâtre britannique» (1949-1950).91

però afegint-hi sense cap explicació una data distinta en cada cas — «Acción...» (1939), «El protagonista...» (1940), «El personaje...» (1941)—, dins La voz iluminada. Notas sobre el teatro a través de un cuarto de siglo (Barcelona: Instituto del Teatro, 1952), 76-111.

9o La conferència era el resultat d'un viatge recent que havia fet a França i Itàlia: «"El teatro —afirmó - sigue en pie”. Contra pesimistas y desorientados puede afirmarse que todavía hoy la escena apasiona a las muchedumbres y ofrece posibilidades estéticas extraordinarias. Se refirió después a lo que pudiera llamarse "buenos modos de la escena europea"; el amor al oficio de los profesionales del teatro y el cuidado con que se estudian los detalles. La persistencia de las obras clásicas y de algunas modernas indica hasta qué punto se continúa en la buena línea. Aludió a algunas obras de Sartre, Romains, Malaparte y Anouilh, y se refirió a la valoración de lo español en los teatros parisienses. Resaltó la importancia del teatro de Alfieri, cuyo centenario se está celebrando estos días, y del que obtuvo interesantes conclusiones», «Don Guillermo Díaz-Plaja, en el Instituto del Teatro», La Vanguardia Española, 28 abr. 1949, 10.

91 En un altre ordre de coses, es van fer homenatges a Eduardo Marquina arran de la seva mort el 1946, amb motiu de la celebració del IV Centenari del naixement de Cervantes el 1947, i a l'actriu 
L'obertura de les activitats de la institució cap a la realitat cultural contemporània es va fer també explícita en les representacions de final del curs dels alumnes de Declamació, ${ }^{22}$ que no es van limitar ja només a la tradició dramàtica espanyola, sinó també a la universal, sobretot contemporània. Si no m'erro, el canvi tot just s'esbossa amb l'elecció de l'acte primer de Bodas de sangre (curs 1946-1947) i fa el seu tomb el curs 19481949 quan per als exàmens finals es van triar escenes de La hermosa gente de William Saroyan; Electra d'Eugene O'Neill; Antígona de Jean Anouilh; El mozo que se casó con mujer brava d'Alejandro Casona, i Primavera en otoño de Gregorio Martínez Sierra. Amb una autèntica magrana final: la representació el 10 de juny de 1949 a la plaça del Rei, arran del I Congrés Diocesà d'Acció Catòlica, d'Asesinato en la catedral,93 de T. S. Eliot,

Aurora Bautista, que havia estat alumna i premi extraordinari de final de carrera a l'Institut. Vegeu Bohigas, Memoria del curso 1946-47, 10; Picó, Memoria del curso 1947-48, 8, i Ramón Picó CAPdevILA, Memoria del curso 1948-49 (Barcelona: Instituto del Teatro. Diputación de Barcelona. Conservatorio Superior de Barcelona), 6, respectivament.

92 En relació amb l'alumnat, el 30 de maig de 1949, els de primer curs van enviar una carta al president de la Diputació, encapçalada per l'alumne José Luis Miranda López, en què assenyalaven que s'havien «visto desagradablemente sorprendidos de que pocos días antes de la celebración de los correspondientes exámenes y sin previas advertencias anteriores, les ha sido modificado sensiblemente, tanto el precio de los derechos de examen, como también el número de asignaturas afectas a dichos exámenes. Estas decisiones son causa de un doble perjuicio a los alumnos, en primer lugar por el quebranto económico que representan y que pueden impedir a todos o algunos de los firmantes formalizar sus matrículas por falta de medios para ello, y esto después de haber asistido durante el curso con el mayor entusiasmo. Por otra parte, el aumento de asignaturas dispuesto en vigilia de los exámenes, coloca a los alumnos en una situación de deficiencia pedagógica por no estar preparados para los ejercicios». Tanmateix, les modificacions del programa i dels drets d'examen van ser desestimades per la Comissió d'Educació, Esports i Turisme el 1o de juny «por estar uno y otros en consonancia con los acuerdos adoptados por la Diputación Provincial», Q-990, AGDB. Vegeu també la resposta, el 15 de juny, a l'alumna Miranda López del secretari accidental de l'organisme provincial, en què es desestima «la instancia de los alumnos del primer curso del Instituto del Teatro, que solicitaban modificaciones en el programa de examen, y en el pago de los derechos de examen, por estar uno y otros en consonancia con los acuerdos adoptados por la Diputación Provincial», A-75/10, AAH. De fet, una «Ordenanza» sobre «Administración de las tasas de instrucción pública», amb la referència a l'augment de les taxes de matrícula i d'exàmens, havia estat aprovada per la Comissió d'Educació, Esports i Turisme el 19 de novembre de 1949 (vegeu Q-985, AGDB).

93 L'obra, dirigida per Artur Carbonell i Marta Grau, es va representar a la plaça del Rei. Vegeu «El Congreso Diocesano de Acción Católica», La Vanguardia Española, 11 juny 1949, 13; Esteban MoLIST PoL, «Asesinato en la Catedral», El Correo Catalán, 15 juny 1949; Julio CoLL, «El Teatro. Asesinato en la catedral», Destino 619 (18 juny 1949): 18-19. 
premi Nobel 1948, que va coincidir en el temps amb la preparació i l'estrena de Cocktail Party, del mateix Eliot, el 30 de maig, pel grup Thule. ${ }^{94}$

Tal vegada les activitats de l'Institut del Teatre van començar a fer un tomb més significatiu a partir del curs 1948-1949, coincidint en el temps amb les eleccions municipals per terços (familiar, sindical i corporatiu) del 21 de novembre de 1948 i amb un panorama cultural barceloní i català un pèl més obert d'ençà del desenllaç de la Segona Guerra Mundial amb evidències com la lenta represa editorial en llengua catalana, la revifalla del món editorial en llengua espanyola i un actiu moviment cultural clandestí, amb totes les limitacions i restriccions que eren del cas.

Un parell de fets van incidir directament en la relació de futur de DíazPlaja i l'Institut del Teatre, com a conseqüència de les eleccions municipals en el temps de l'alcaldia de Josep M. Albert i Despujol, baró de Terrades (1945-1951). El primer fet està relacionat amb la personalitat de Luis de Caralt, que per poc temps havia estat ponent suplent i titular (1944-1945 i 1945-1946, respectivament) de la Comissió Gestora de la Diputació de Barcelona. En les eleccions municipals esmentades, Caralt va ser elegit pel terç familiar i a partir del febrer de 1949 es va convertir en tinent d'alcalde i delegat de Cultura de l'Ajuntament de Barcelona fins a les eleccions de novembre de 1951. Posteriorment no es va desvincular del tot de l'Ajuntament, perquè va continuar presidint durant un temps el premi de narrativa Ciudad de Barcelona, que va ser aprovat pel Ple de l'Ajuntament de Barcelona el 8 de juliol de 1949 i va ser concedit per pri-

94 Mariano de la Cruz, que va muntar Cocktail Party, explica les vicissituds del muntatge d'Asesinato en la catedral, que va proposar-li Díaz-Plaja: «Llavors a ell se li va acudir muntar Asesinato en la catedral que, naturalment, podia ser també la primera obra d'Eliot que es representés a Espanya. En lloc d'arribar a un acord va imposar que els actors que sortissin a la meva obra no sortirien a la seva, i com que Thule treballava amb alumnes de l'Institut que no cobraven res perquè no teníem diners, em vaig quedar en quadre un mes abans de l'estrena. Va ser fotut perquè el text d'Eliot [Cocktail Party] era dur i en aquella època encara anàvem amb l'apuntador amagat al coverol o entre bastidors. Va ser dur i complicat», Jaume BoIx \& Arcadi EsPADA, Mens sana in corpore insepulto. Últimes converses amb Mariano de la Cruz, Biografies i Memòries 52 (Barcelona: Edicions 62, 2002), 6o-61. D’altra banda, es conserva una còpia de la carta que Díaz-Plaja va enviar a Jacinto Guerrero, president de la Sociedad General de Autores de España. Li demanava la seva intercessió prop dels agents d'Eugene O'Neill, en relació amb el pagament del drets d'autor del muntatge del grup Thule sobre El Gran Dios Brown (vegeu A-79/5, AAH). Sobre el grup Thule, vegeu Enric GallÉn, El teatre a la ciutat de Barcelona..., 235-238; Ernesto Carratalá, Memorias de un piojo republicano (Pamplona: Pamiela, 2007), 307-319. 
mer cop el 26 de gener de 1950, data de l'ocupació franquista de la ciutat de Barcelona. Caralt, un excombatent, havia estat un dels falangistes catalans de la primera hora i era en aquell moment, a més, un editor que competia amb Josep Janés per incorporar determinats autors estrangers de postguerra, traduïts a l'espanyol, com ara James McCain, William Faulkner i Ernst Hemingway, o Georges Simenon i Graham Greene — va ser el primer a publicar aquests darrers en l'àmbit de l'Estat.95 El segon fet és que la Comissió Gestora de la Diputació va donar pas a la Diputació Provincial, presidida a partir del 24 d'abril de 1949 per Joaquim Buxó de Abaigar, futur marquès de Castellflorite (1951), ${ }^{96}$ que ja havia estat membre de la Comissió Gestora nomenada el 1946, i era un dels regidors escollits pel terç professional en les eleccions municipals.

Atesa la nova situació creada en la política local i provincial, Díaz-Plaja va jugar-hi a fons com a màxim responsable de l'Institut del Teatre, tan a fons com li ho van permetre les circumstàncies generals, les polítiques i les personals. ${ }^{97}$ Va procurar convertir la institució teatral en una ambiciosa baluerna que li servís com a plataforma de projecció personal en el món cultural espanyol i hispanoamericà, ${ }^{98}$ alhora que va mostrar una

95 Manuel Llanas, L'edició a Catalunya: el segle XX (1939-1975), amb la collaboració de Montse Ayats (Barcelona: Gremi d'Editors de Catalunya, 2006), 228-232. Posteriorment, Luis de Caralt va ser substituit per José Maluquer com a ponent de Cultura, que ja va participar en la sessió del 29 d'abril de 1952 del Consell Rector del Conservatori Superior de Música i Declamació de Barcelona. Vegeu Fons Artur Sedó i Guixard, Ms. 216o/1. 3, Biblioteca de Catalunya.

96 Juan Sedó Peris-Mencheta, fill d'Arturo Sedó Guixard, va ser nomenat president de la Comissió d'Educació, Esports i Turisme, amb José Emilio de Maqua Sagnier, com a vicepresident. Sobre Sedó Peris-Mencheta, vegeu P. VILA-SANJuÁN, «Semblanza de don Juan Sedó Peris-Mencheta», $A B C$, 10 abr. 1966, 87-88. Vegeu també Josep Maria CoRTÉs, «Crónicas burguesas. El legado de los Sedó», Suplement Dinero de La Vanguardia, 11 oct. 2009, 12-13.

97 L'1 de juny de 1949 va ser nomenat vocal del Consejo Superior de Teatro pel Ministerio de Educación Nacional (BOE, 3 juny 1949).

$98 \mathrm{El}$ juliol de 1946 va iniciar a Argentina el seu periple continuat al llarg dels anys per terres americanes. En la seva primera estada a Argentina, va impartir cinc conferències, entre les quals una dedicada a Terra baixa de Guimerà, que va publicar «En el 50 aniversario de Terra Baixa», Boletín de la Academia Argentina de Letras, vol. xv, 54 (1946): 425-445. En tornar de les Amèriques, el 30 de novembre de 1946, va ser homenatjat per professors i alumnes, «Homenaje a Don Guillermo DíazPlaja», dins BoHIGAs, Memoria del curso 1946-47, 10. Com a mostra també del seu interès personal, ben viu en els anys trenta, per la figura de García Lorca, va publicar a Buenos Aires Federico García Lorca: estudio crítico (1948). Segons Jordi АMAT, el «va deixar gairebé enllestit» durant la guerra, $E l$ llarg procés..., 73 . 
calculada sensibilitat per determinades figures de la literatura catalana de postguerra, en el que no deixava de ser una proposta limitada de normalització cultural.

Díaz-Plaja va fer també un pas més en la restauració i reconeixement del nom i la figura d'Adrià Gual, discretament homenatjada arran de la seva mort el $1943 .{ }^{99}$ Amb l'excusa del cinquantè aniversari d'inauguració del Teatre Íntim, va decidir retre-li un homenatge amb un ampli compromís institucional i un ressò públic que no havia tingut el decés del fundador de la institució. ${ }^{100}$

99 Vegeu GALLÉN, «Supervivència i mort d'Adrià Gual...». Posteriorment, el 1945, la vídua d'Adrià Gual va oferir a la Diputació Provincial de Barcelona la compra «de unos lotes formados por una considerable parte de los bocetos y proyectos teatrales que produjo dicho artista. Teniendo en cuenta que el Instituto del Teatro se propone dar a su Museo la amplitud que corresponde a la importancia y dignidad de la tradición teatral barcelonesa. Considerando, además, la indudable jerarquía artística de don Adrián Gual, reconocida por la opinión unánime de la crítica. No olvidamos, por otra parte, la circunstancia de haber sido el señor Gual el primer director del Instituto del Teatro. El infrascrito, no disponiendo en las consignaciones destinadas al funcionamiento normal del Instituto, de cantidad para esta adquisición, tiene el honor de proponer que la Excma. Diputación Provincial habilite el crédito que crea necesario y le sea posible para adquirir alguno de los lotes ofrecidos, destinándolos al expresado Museo del Instituto del Teatro», segons l'ofici que Díaz-Plaja va adreçar el 24 de desembre al diputat ponent de Cultura de l'organisme provincial. En la seva resposta, el 28 de desembre, el ponent de Cultura demanava a Díaz-Plaja «la composición del lote que cree sería conveniente adquirir, indicando la cuantía del mismo», Q-583/7, AGDB. En un altre document, s'assenyala que «se han hecho varios lotes, valorándose cada uno de ellos en 15.000 ptas, siendo el precio total del conjunto de lotes el de 50.000 ptas.» La compra dels lots de l'obra de Gual no va prosperar perquè «por el momento la Diputación no podrá atender el gasto que representa dicha adquisición. Esto no obstante, precisa indique cual de los lotes ofrecidos se crea más oportuno poseer el Instituto, para que esta Ponencia pueda realizar, en su día, las gestiones oportunas a fin de lograr su posesión», segons un ofici signat pel ponent de Cultura el 22 de febrer de 1946 (vegeu Q-621, AGDB).

100 Es va crear una Comissió d'Honor formada per José Emilio de Maqua, ponent de Cultura de la Diputació; Tomàs Carreras Artau, tinent d'alcalde i delegat de Cultura de l'Ajuntament de Barcelona; el marquès d'Alfarràs; el marqués de Lozoya, director general de Bellas Artes; Eugeni d'Ors; Enric Borràs; Lluís Duran i Ventosa; José Pardo, delegat provincial d'Educació Popular, i Diego Ramírez Pastor, president de l'Associació de la Premsa. La Comissió executiva va ser presidida per Díaz-Plaja. Tomàs Roig i Llop n'era el vicepresident. Com a vocals hi havia Isabel Llorach, Roser Coscolla, Octavi Saltor, Ramon Barbat, Domènec Juncadella. Oriol Bohigas exercia de secretari. Entre els actes d'homenatge, que es van celebrar, podem destacar els següents: el 21 d'abril, al Saló de Cent, Ors va fer una conferència inaugural sobre Gual, i Enric Borràs va llegir alguns poemes de Gual davant les autoritats municipals; el 23 d'abril, Ràdio Barcelona va emetre Donzell qui cerca muller, de Gual, a càrrec de l'elenc de ràdio teatre que dirigia Armand Blanch; el 9 de maig, es va inaugurar l'aula Adrián Gual a l'Institut del Teatre. Quant a les representacions de l'obra de Gual, el 5 de maig, la companyia d'Elvira Jofre i Pere Gener va oferir El fals Albert, al Teatre Romea, i el 14 de maig, a l'Orfeó Gracienc, Bartomeu Olsina va dirigir Arlequí vividor, Joan Fornaguera va dirigir 
Com es podia fer perceptible la presència d'una determinada realitat cultural i teatral catalanes en l'organització docent i en el conjunt de manifestacions organitzades per una institució espanyolitzada? Fins a quin punt la represa pública del teatre autòcton professional en llengua catalana podia incidir en les directrius culturals i els objectius artístics immediats del centre? En la segona meitat dels anys quaranta va continuar sent l'excepció de la regla, però amb alguns detalls testimonials. Quant a les manifestacions organitzades al marge de l'activitat docent, podem ressenyar alguns actes. El 31 de març de 1946 l'actriu Mercè Nicolau, alumna sorgida de l'Escola Catalana d'Art Dramàtic, va fer un recital poètic en què va incloure El trilleig ressuscitat del prevere Josep M. Llovera. El mateix Díaz-Plaja va fer una conferència sobre la «Significación literaria de Ángel Guimerá» (11 abril 1947). Mentre que arran del centenari de les emissions radioescolars, Bartomeu Olsina va recitar l'Oda a Barcelona, de Verdaguer (30 juny 1947). Van ser convidats també Josep M. de Sagarra (15 febrer 1949) i Josep M. López-Picó (17 abril 1950), perquè fes-

\footnotetext{
Misteri de dolor amb Mercè Nicolau de protagonista i Josep Clapera va dirigir Camí, una obra pòstuma de Gual (vegeu A-118/24, AAH). En un altre ordre de coses, es va convocar un concurs d'articles periodístics dedicat a l'obra i a la personalitat de Gual, «publicado en cualquier periódico de España, en el idioma nacional o en los regionales, hasta el zo de abril próximo», «Del Homenaje a Adrián Gual. Concurso de trabajos periodísticos», La Vanguardia Española, 17 març 1949, 8. El primer premi, de 500 pessetes, va ser declarat desert, «pero se hace una mención especial del artículo "Adrián Gual, el innovador", de don Enrique Rodríguez Mijares que, por la fecha de su publicación, no ha podido ser incluido al referido concurso». L’article de Rodríguez Mijares s'havia publicat al Diario de Barcelona el 30 de gener de 1949 amb motiu de la commemoració del cinquantè aniversari de la fundació del Teatre Íntim, i abans de fer-se pública la convocatòria del concurs. Es va concedir un accèssit de 300 pessetes a l'article «Adrián Gual, gran idealista», de Tomàs Caballé Clos, i un altre de 250 pessetes al de Joaquín Ciervo, «Adrián Gual, en el recuerdo»; vegeu «Conmemoración de Adrián Gual. Comisión Ejecutiva», La Vanguardia Española, 8 juny 1949, 12. De manera significativa, Josep Pla va escriure "Adrián Gual», un article molt crític amb els qui havien qüestionat en vida l'obra de Gual, si bé, malgrat el màxim respecte cap al creador de l'Escola Catalana d'Art Dramàtic, no va poder reprimir el seu rebuig cap al modernisme: « ¿qué tuvo el modernismo para que los adheridos a esta escuela guardaran tanta fidelidad a sus principios? Esta fidelidad se explica, a mi entender, por la fascinación que sintieron por lo artístico. Sin embargo, lo artístico es un mal camino. Lo que durará menos en la obra de Gual es exactamente lo artístico. Gual fue demasiado fiel a su época, demasiado presentista», Diario de Barcelona, 28 abr. 1949, 2. Vegeu també un altre paper datat el 1955: Josep PLA, «Adrià Gual, home de teatre», dins Retrats de passaport, Obra Completa 17 (Barcelona: Edicions Destino, 1970), 105-109.
} 
sin sengles recitals arran de la publicació del seus corresponents volums d'Obra Completa per Editorial Selecta. ${ }^{101}$ I poca cosa més.

Quant a l'organització docent de l'Institut del Teatre, la relació de les matèries de les tres seccions a finals del curs 1948-1949 era la següent:

\section{Secció de Declamació}

1r. curs.- Recitació; Rítmica; Teoria de la Literatura; Direcció Escènica; caracterització; Lectura expressiva.

2on. Curs.- Història del Teatre; Lectura expressiva, Declamació; Història de la Cultura; Caracterització.

3r. curs.- Pràctica teatral; Caracterització; Història del Teatre; Història del vestit i de les arts sumptuàries.

\section{Secció de Dansa}

1r. curs.- Dansa clàssica; Ball espanyol; Història de la Cultura. 2on.- Dansa clàssica; Ball espanyol; Història de l'Art; Caracterització. 3r., curs.- Dansa clàssica; Ball espanyol; Història de la Dansa; Història del vestit i de les arts sumptuàries.

\section{Secció d'Escenografia}

1r.- Perspectiva; Dibuix; Història de la Cultura. 2on.- Escenografia teòrica; Figurins; Història de l’Art; Caracterització.

3r.- Escenografia pràctica; Realitzacions escèniques; Història de l'Art; Història del vestit i de les arts sumptuàries. ${ }^{102}$

Durant el curs 1949-1950 es van produir alguns canvis significatius en l'àmbit docent en relació amb la realitat cultural catalana en incorporar

101 El 1948 les Obres Completes de López Picó van inaugurar la Biblioteca Excelsa de l'Editorial Selecta, mentre que Sagarra va publicar entre 1948 i 1949 els dos primers volums de les seves Obres Completes, dedicats al teatre. Parallelament, el mateix 1949 Díaz-Plaja va iniciar la direcció de la Historia general de las literaturas hispánicas, a càrrec de l'Editorial Barna d'Albert Puig-Palau, en sis volums; una Historia en què van collaborar, entre altres, Miquel Dolç, Manuel de Montoliu, Pere Bohigas i el seu mestre Jordi Rubió i Balaguer. Vegeu Jaume Fabre \& Xavier Febrés, Tío Alberto: vida, secreto y fiesta de Alberto Puig Palau (Barcelona: La Esfera de los Libros, 2007), 101-105.

102 «Los estudios teatrales en España», text inèdit mecanografiat, A-70/4, AAH. 
Danses catalanes ${ }^{103}$ i Declamació catalana. ${ }^{104}$ Parallelament, Díaz-Plaja va exposar la seva situació personal en considerar «totalmente realizada la labor de creación de enseñanzas que se propuso al tomar la posesión de la Dirección del Instituto en 1939.» Un cop «completado el cuadro de enseñanzas aludido y obtenida la dotación correspondiente para todas y cada una de las asignaturas que se estimaban necesarias», Díaz-Plaja va presentar al president de la Comissió d'Educació, Esports i Turisme, el 31 d'octubre de 1949, una proposta de modificació del seu estatus acadèmic:

Al resolverse el Concurso-oposición que en su día fue convocado para proveer en propiedad la Dirección del Instituto del Teatro, se acordó que el nuevo Director debería alternar las funciones directivas con la enseñanza de una cátedra. En este sentido el Director que subscribe figura al frente, desde 1939, de tres enseñanzas: Teoría de la literatura, Historia del Teatro (Antiguo y Medio) e Historia del Teatro (Moderno y Contemporáneo) que se explican a los alumnos de $1^{\circ}, 2^{\circ}$ y 3 er. Curso de la Sección de Declamación.

No habiendo sido dotadas de manera especial ninguna de estas tres cátedras, se da el caso de que el Director que subscribe, percibe como todo emolumento una suma de 750,0o pesetas mensuales. Es evidente que este criterio no es el que ha regido, por ejemplo, en lo que afecta a la provisión de la Secretaría, criterio que ha hecho posible la percepción de la dotación que le corres-

103 Díaz-Plaja va enviar un escrit al president de la Comissió d’Educació, Esports i Turisme el 24 d'abril de 1950, en què reclamava i justificava la creació de Danses Catalanes com a complement de la Dansa Clàssica i el «Baile Español» en aquests termes: «cree esta Dirección que se padece un grave olvido no incluyendo en nuestro plan de trabajo, por lo menos, un curso de Danzas catalanas, cuya riqueza asombrosa, cuyos valores estéticos y cuya entrañable relación con el Instituto no es necesario ponderar. En un régimen que de manera tan admirable ha venido salvando del olvido las danzas populares de toda España creemos obligado que no falte en el Instituto del Teatro una manifestación tan importante y tan llena de interés». De l'assignatura en tindria cura «un encargado de curso, un ayudante y un acompañante de piano", segons l'acreditació del secretari accidental de la Diputació Provincial de Barcelona, el 9 de maig de 1950 (vegeu Q-99o, AGDB).

104 «con carácter voluntario para los alumnos de tercer curso de Declamación, y con una hora semanal de clase», segons la «Diligencia» acreditada el 5 de novembre de 1949 per Juan Sedó Peris Mencheta, president de la Comissió d’Educació, Esports i Turisme (vegeu ibídem). Entre 1948 i 1949 s'hi van incorporar també com a professors auxiliars Maria Teresa Jornet (Literatura), José García López (Història de la cultura), Dolores Rusca (Danses catalanes) i Laureano Higueras (Perspectiva). Posteriorment, a primers de 1952, Higueras es va traslladar al Brasil i va ser substituït per Andreu Vallvé Ventosa (vegeu A-75/1, AAH). 
ponde a dicho cargo y la conservación de un sueldo de Profesor, con lo que estos emolumentos sobrepasan los que la Dirección percibe.

Por todo ello, el Director que subscribe ruega respetuosamente que las Cátedras que viene explicando desde la toma de posesión de su cargo sean dotadas en el presupuesto próximo, para lo que solicita sea incluida una partida única de pesetas 4.800 anuales correspondiente al concepto «Un Catedrático de Teoría de la Literatura e Historia del Teatro», y que sea autorizado para cobrar, como ya se ha hecho en el caso de la Secretaría, dicha asignación en concepto de gratificación. ${ }^{105}$

La proposta va ser ben acollida, es va acceptar la gratificació sollicitada de 4.80o pessetes anuals i es va crear «una nueva Cátedra de Historia del Teatro (Historia del Teatro Antiguo y Medieval para los alumnos de $2^{\circ}$ curso, e Historia del Teatro Moderno y Contemporáneo para los alumnos de $3^{\circ}$. Curso)en el Instituto del Teatro(ConservatorioSuperior de Barcelona)». ${ }^{106}$

Finalment, en la Sessió Plenària de la Diputació Provincial del 19 d'agost de 1950, es van crear «para ser adaptadas sus enseñanzas a las correspondientes a Conservatorio Superior las cátedras de Historia del Teatro, Dibujo geométrico y arquitectónico, Declamación catalana y Danzas catalanas encomendándose dichas enseñanzas respectivamente a los señores don Guillermo Díaz-Plaja, don Montserrat Galmés Melis, doña Rosario Coscolla y don José Zaldívar Ruíz». ${ }^{107}$

\section{Ascensió i caiguda del projecte del «Teatro de la Ciudad»}

La gran aposta personal i política de Díaz-Plaja com a director de l'Institut del Teatre durant el primer franquisme va girar entorn del projecte del

105 Q-990, AGDB.

106 La resolució signada pel cap de la Secció de Cultura el 20 de juny de 1949 va comptar amb la conformitat de la Comissió d'Educació, Esports i Turisme (22 de juny) i de la Comissió de Governació (7 de juliol), la qual va proposar «elevar el oportuno dictamen al Pleno de la Diputación», Q-99o, AGDB.

107 Ofici de Díaz-Plaja (1 de novembre de 1950) adreçat a Juan Sedó Peris-Mencheta, diputat de la Comissió d'Educació, Esports i Turisme de la Diputació Provincial de Barcelona. De cara al curs 19501951, Lluïsa Pujol Givanel va ser designada per a la plaça d'auxiliar d'acompanyant de Danses Catalanes, segons la diligència de la Comissió d'Educació, Esports i Turisme de la Diputació Provincial de Barcelona, datada el 29 de novembre de 1950, que presidia Juan Sedó Peris-Mencheta (vegeu ibídem). 
«Teatro dela Ciudad». ${ }^{108}$ La proposta partia d'uns determinats antecedents. D'una banda, la proposta fallida del Teatre de la Ciutat, ${ }^{109}$ de Lluís Duran i Ventosa, que havia estat diputat ponent d'Instrucció Pública i Belles Arts de la Diputació, i una peça fonamental en el procés d'instauració dels primers anys de l'Escola Catalana d'Art Dramàtic;', ${ }^{110}$ també regidor regionalista responsable de Cultura de l'Ajuntament en els primers anys vint, i conseller de Cultura de la Generalitat després del 6 d'octubre de $1934 \cdot{ }^{111}$ De l'altra, el bon funcionament i el reconeixement artístic de crítica i públic dels dos «Teatros Nacionales», creats el 1940, que hi jugava a favor.

Segons que sembla, Caralt va treure el tema en el decurs de la seva campanya municipal; probablement Díaz-Plaja hi va veure una oportunitat de dir-hi la seva i va començar a posar fil a l'agulla ben aviat. Quan feia molt poc que s'havia constituït el nou equip municipal, ${ }^{112}$ Díaz-Plaja va redactar un parell de fulls mecanografiats, amb data de 22 de febrer de 1949, en què asseverava que «el Excmo. Ayuntamiento de B. se propone

108 Vegeu Gallén, «Els intents de creació d'un Teatre Municipal...», 170-178.

109 (Barcelona: Publicacions de l'Escola Catalana d'Art Dramàtic, des. 1921). Sobre el tema, vegeu Raffaella Perrone, Espacio teatral y escenario urbano. Barcelona, entre 1840 y 1923 (tesi doctoral, Universitat Politècnica de Catalunya, 2011); Margarida CASACuberta, Francesc Foguet, Enric GALlÉN \& Miquel M. GiBERT, «La institucionalització teatral de la Mancomunitat (1914-1923)», dins El debat teatral a Catalunya. Antologia de textos de teoria i crítica dramàtiques. Del Modernisme a la Guerra Civil, Escrits Teòrics 15 (Barcelona: Diputació de Barcelona. Institut del Teatre, 2011), 52-56.

110 Vegeu Guillem-Jordi Graells, «Els antecedents i la fundació», dins L'Institut del Teatre..., 14-15.

111 Quan va ser entrevistat sobre el projecte de Díaz-Plaja, Duran i Ventosa es va queixar que no s'hagués fet esment de la seva proposta de 1921: «Lo cierto es que de aquellos buenos propósitos de antaño ni el más vago recuerdo debe perdurar. Lo demuestra el hecho de que nadie se ha referido hasta el presente a cuanto dejo consignado. De todos modos cuantos permanecemos atentos siempre a las cosas de Barcelona y manifestamos una fidelidad absoluta a los sentimientos de la juventud, seguimos con satisfacción ese interés creciente por el Teatro Municipal y desearíamos que el proyecto adquiriera formas concretas que aseguraran su probada eficacia», «¿Qué opina Vd.? El nuevo proyecto de Teatro Municipal. ¿Tiene idea de lo que puede ser y dónde se emplazaría?», El Correo Catalán, 23 oct. $1949,6$.

112 El 6 de febrer de 1949 va tenir lloc la sessió amb els «concejales electos con el fin de proceder a la constitución del nuevo Ayuntamiento", Actes del Ple de l'Ajuntament de Barcelona [1948-1949, p. 7], 4767 C-8 A-134, Arxiu Contemporani de Barcelona. Caralt va ser nomenat Tinent d'Alcalde Delegat de Cultura. La Comissió de Cultura Permanent va ser constituïda per Caralt com a president i Melchor Baixas de Palau, Juan Torra-Balari, Juan Gil Senis i Cosme Puigmal com a vocals (vegeu ibídem, p. 105). 
resolver este ya viejo problema que tanto afecta al nivel cultural de nuestra ciudad». ${ }^{113}$ Ell hi veia tres solucions:

Primera.- Cabe la simple tarea de tomar en arriendo un determinado teatro y facilitarlo en determinadas condiciones a los grupos teatrales que previo concurso vayan ofreciendo programas de más alta calidad artística.

Esta solución no ofrece garantía ninguna por su falta de estabilidad y por no caracterizar de una manera enérgica la gestión municipal que ha de llevar a término un verdadero «Teatro de la Ciudad».

Segunda.- Podría resucitarse el famoso concurso que, embargado por la misma preocupación nuestra, convocó el Ayuntamiento de Barcelona en 1921, lo que dio lugar a una violentísima polémica por considerarse que no habían sido atendido todos los factores necesarios.

Esta segunda solución es también poco viable. Levantar un gran teatro de planta supone un esfuerzo colosal y el solar que el Estado ha destinado (Vía Layetana frente al Fomento del Trabajo Nacional) no parece el más indicado para atraer al público. El concurso de proyectos provocaría una nueva polémica y la ejecución de las obras demoraría enormemente la realización de nuestro deseo.

Tercera.- Queda una tercera posibilidad. A mi juicio la más interesante y viable: se trataría de devolver a la ciudad el edificio que desde el siglo XviI constituye su teatro más representativo: El Teatro de la Santa Cruz, hoy Principal Palace, dependiente del Hospital de la Santa Cruz que durante el siglo XIX constituyó el rival dignísimo del Liceo dando lugar a la famosa pugna entre «liceístas» $\mathrm{y}$ «cruzados».

A mi juicio las ventajas de esta solución son

a) La existencia de un cuerpo de edificio absolutamente capaz y con suficiente aforo.

b) La nobleza de sus líneas que resaltará cuando se dignifique la fachada eliminado de ella los carteles que la afean. 
c) La tradición trisecular de este teatro, situado precisamente en la Plaza del Teatro, y en uno de los lugares de más solera barcelonesa.

d) La proximidad al Teatro del Liceo lo que garantiza que un público tan selecto como el que acude a las veladas de ópera podría asistir al «Teatro de la Ciudad».

e) La continuidad de una tarea de dignificación de la Rambla cuyas etapas son la Virreina, el Museo Marítimo, la proyectada apertura de la vía que unirá Atarazanas a Muntaner, el Museo del Teatro instalado en el Palacio Güell, etc., etc.

f) La oportunidad extraordinaria por la que atravesamos de que es posible una operación de compra que caso de perderse impedirá para siempre esta dignificación ciudadana y de restauración de uno de los valores característicos de la historia de nuestra ciudad.

\section{Barcelona, 22 de Febrero de $1949^{114}$}

Efectivament, a partir del mes de febrer de 1949, es va iniciar un procés ${ }^{115}$ que va viure el seu moment més àlgid i estellar entre els mesos de setembre i novembre d'aquell any. El pas següent al document de febrer va ser l'elaboració d'un Proyecto de Teatro de la Ciudad, ${ }^{116}$ que segons ell va dur a terme a instàncies de Luis de Caralt:

Siguiendo la pista de una interesante noticia, averiguamos que había sido presentado al Consistorio Municipal un detallado proyecto referente a su instalación y organización, debido al director del Instituto del Teatro de la Diputación Provincial, don Guillermo Díaz-Plaja.

114 Ibídem.

115 «De la Tenencia de Alcaldía Delegada de Cultura (Negociado de Cultura) fueron aprobados los siguientes dictámenes. Uno Proponiendo.- Que se autorice a la Tenencia de Alcaldía Delegada de Cultura, para que, de acuerdo con la Agrupación Técnica de Edificios Municipales, pueda formular el proyecto de creación del Teatro Municipal y salas de concierto y exposiciones, sometiéndolo en su día a la oportuna consideración de la Excma. Comisión Municipal Permanente», Llibre d’actes de la Comissió Municipal Permanent [del 26 d'abril al 18 de maig de 1949, volum 6], 569, Arxiu Contemporani de Barcelona. El mes d'agost Ángel Zúñ IGA va publicar un parell d'articles sobre el tema: «Necesidad de un teatro», La Vanguardia Española, 19 ag. 1949, 2; «Un teatro en la ciudad», La Vanguardia Española, 31 ag. 1949, 2.

116 Vegeu annex 7. 
Preguntado por nosotros, nos ha manifestado lo siguiente:

- Para cuanto nos interesamos por la dignificación del teatro, el tema de la creación de un Teatro municipal no puede sernos indiferente. Hace mucho tiempo que por indicación expresa de mi querido amigo, el teniente de Alcalde Delegado de Cultura, don Luis de Caralt, vengo preparando un proyecto de organización de los servicios de un teatro que, libre de la preocupación económica del teatro comercializado, pueda ofrecer constantemente a Barcelona el espectáculo de dignidad cultural y artística a que por su tradición tiene derecho. $^{117}$

\section{El mes de setembre d'aquell any, la Comissió Permanent de l'Ajuntament de Barcelona va aprovar una proposta que s'inscrivia en el marc d'un pressupost municipal extraordinari destinat a l'embelliment i a la mo- dernització de la ciutat. ${ }^{118}$ La proposta concreta de «construcción de un Teatro municipal» procedia de Luis de Caralt, tinent d'alcade delegat de}

117 «El Teatro Municipal en el edificio del Principal Palacio. Interesante proyecto del Director del Instituto del Teatro", Solidaridad Nacional, 14 set. 1949, 2.

118 «Don ENRIQUE DE JANER Y DURÁN, Licenciado en Derecho, Secretario interino del Excmo. Ayuntamiento de Barcelona, CERTIFICO: Que en el Negociado de Cultura de la Sección administrativa de Gobernación de esta Secretaría Municipal, figura un expediente por el que la Excma. Comisión Municipal Permanente, en sesión del día diez y ocho de mayo de mil novecientos cuarenta y nueve, acordó la construcción de un Teatro municipal, pasando a la Comisión de Cultura para su estudio y consideración. CERTIFICO ASIMISMO: Que en el expediente de elaboración del Proyecto de Presupuesto Extraordinario, denominado de Modernización y Extensión de Barcelona, figura con el número diez el proyecto de construcción de una sala municipal de conciertos y exposiciones, proyectada en treinta millones de pesetas. CERTIFICO IGUALMENTE: Que por el señor Arquitecto Jefe del Servicio de Edificios Culturales, ha sido redactado un proyecto para expropiaciones y estructura del Teatro municipal de Barcelona, por importe de seis millones de pesetas, que ha sido aprobado en la esfera de su competencia por la Comisión consistorial de Cultura. Y PARA QUE CONSTE y pueda surtir sus efectos en el expediente de transferencias, habilitaciones y suplementos de crédito en el Presupuesto Extraordinario de Modernización y Extensión de Barcelona, libro la presente, de orden del Excmo. Señor Alcalde, visada por el mismo y sellada con el que usa esta Corporación, en Barcelona, a veintitrés de febrero de mil novecientos cincuenta. visto Bu ENO. EL ALCALDE. B. de Terrades», Ayuntamiento de Barcelona. Sección de Hacienda. Negociado de Presupuesto. Expediente núm. 2402, 67, Arxiu Contemporani de Barcelona. En la Memoria del presupuesto extraordinario de modernización y extensión de Barcelona ( $1^{a}$ etapa - 1947), conservada a l'Arxiu Contemporani de Barcelona, hi consta com a proposta número 10 de la Tenencia de Alcaldía Delegada de Cultura, la «construcción de una sala municipal de conciertos y salas de exposiciones» amb un pressupost de trenta milions de pessetes. La memòria va ser redactada per G. de Azcoitia, tinent d'alcalde i president de la ponència d'Hisenda, i datada el 13 de maig de 1947. 
Cultura, i més aviat contrastava amb l'esmentat Proyecto de un Teatro de la Ciudad de Díaz-Plaja, que Caralt havia de conèixer per força. En fer-se pública la decisió de la Comissió Permanent, Díaz-Plaja es va avançar a Caralt fent les primeres declaracions públiques sobre el tema a la premsa. ${ }^{119}$ Va explicar el seu projecte a Solidaridad Nacional, un òrgan afí, ${ }^{120} \mathrm{i}$ va fer arribar les seves explicacions a altres professionals de la premsa i la ràdio perquè en parlessin, ${ }^{121}$ com va fer el crític $\mathrm{Al}$ fonso Flaquer a La Prensa. ${ }^{122}$ Parallelament va fer un entretoc al tinent

119 Sense assenyalar-lo explícitament, un sector de la premsa va esmentar la rapidesa de moviments realitzats per Díaz-Plaja: «Del Teatro Municipal.- Bastó que la Comisión Permanente aprobase el proyecto relativo a la creación de un teatro municipal para que se alborotase el gallinero. Y, sin esperar más, hay quien le ha buscado casa con derecho a cocina y quien ha colocado la primera piedra en un solar. ¡Para escamarse! No queremos meternos hoy en disquisiciones. Pluma tenemos que lleva treinta años al servicio del teatro sin disfrute de cargos atribuidos; pluma templada en el yunque de las sinceridades, y tiempo por delante, si Dios quiere, para hacerlas. Es curioso que la cuestión haya sido llevada al periódico con tanta prisa, buscando la carambola por tabla con taco de casa y boca. Tanto más cuanto que el que ha levantado la liebre, periodísticamente, había acudido ya "por su propia iniciativa" — según palabras del Presidente de la Ponencia de Cultura, señor Caralt-, es decir, en clase de espontáneo, "a ofrecer sus proyectos”. Ya era bastante, ¿no? En casos, como éste, la colaboración debe huir de exhibicionismos que se prestan a comentarios maliciosos. No es prudente "descubrir" paredes cuya adquisición costaría a la ciudad unos milloncetes, sin antes andar y ver si alguno de los solares del Ayuntamiento, es aprovechable. Lo que reclama estudio, global y parcelario, es lo que se va a hacer en ese teatro; lo que importa no es la fachada, sino el contenido escénico: exponer en líneas generales los postulados a desarrollar, su sentido de minorías y de mayorías, lo selecto y lo popular, lo clásico y lo moderno, las posibilidades que se puedan encontrar en él los desconocidos, la parcela reservada a lo de casa y el margen que podría concederse a lo de fuera, sí ha de responder a su misión. Convertirlo en un reducto burocrático sería torpeza imperdonable. De eso debe escribirse; para eso, todas las colaboraciones son necesarias. Conviene tomar posiciones, dispuestos a defenderlas. Y hacer, si llega el caso, cuantas salidas de descubierta convenga para conocer la situación del enemigo, sin miedo ni tacha. No se olvide que el teatro es nuestra razón de vida periodística. Y que la partida hay que jugarla caballerosamente», «Fe de vida. No por mucho madrugar amanece más temprano. Del Teatro Municipal», Barcelona Teatral 449 (22 set. 1949), 2.

120 Vegeu annex 7.

121 Vegeu A-70/42, AAH. Es conserven les còpies de la confirmació de la tramesa personal de les seves declaracions a José Martín d'El Noticiero Universal, a Ricardo Suñé d'El Correo Catalán i a l'escriptor Ramon Aliberch, i també la referència d'una nota informativa enviada als directors de Radio Barcelona EAJ 1, Radio España de Barcelona EAJ, i d’un «Saluda» als crítics teatrals de La Vanguardia Española, Solidaridad Nacional, El Correo Catalán, Diario de Barcelona, La Prensa i Destino.

122 A[lfonso] F[LAQUer], «Unas interesantes sugerencias del doctor Guillermo Díaz-Plaja», La Prensa, 20 set. 1949, 4. Es conserva la còpia de la resposta de Díaz-Plaja del mateix dia: «Mi querido amigo: Dos líneas para darle muchísimas gracias por su ingeniosa nota de comentario a mis sugerencias alrededor del Teatro Municipal y sobre todo por la complacencia que me inspira el proyecto 
d'alcalde ponent d'Hisenda de l'Ajuntament de Barcelona, Francisco Condomines. ${ }^{123}$

Des del primer moment, la polèmica sobre el teatre municipal es va centrar exclusivament en l'espai que l'havia d'allotjar, amb opinions d'alguns professionals del món del teatre ${ }^{124} \mathrm{i}$ una significativa resposta dels lectors de la secció «Cartas al Director» de Destino. Tres espais de referència per a la ubicació d'un Teatro de la Ciudad: al Teatre Principal, al Teatre Novetats o en un espai per definir a la Diagonal; ${ }^{125}$ un plantejament que també va abonar Luis de Caralt en una entrevista amb Del Arco:

- ¿Esto quiere decir que usted prefiere levantar nuevo edificio a aprovechar teatro existente?

- Personalmente, sí, y habida cuenta sobre todo que en este edificio se albergarían además las obras de arte que adquiriera el Ayuntamiento, y se podrán celebrar exposiciones de ellas, antes de ser colocadas en sus museos respectivos; y también servir para sala de conciertos de la orquesta municipal. Para todo esto no conozco ningún edificio.

- ¿Ha pensado sitio?

- Hay tres lugares: muy arriba, en la Diagonal; muy abajo, en las Ramblas; o intermedio, en las calles Caspe o Granvia, de abolengo teatral.

- ¿Tiene dinero?

- Que le conteste el Ponente de Hacienda.

cuyas ventajas espero desarrollar en una ocasión próxima. Cordialmente suyo», Ibídem. Hi ha un petit error en la còpia mecanografiada: el pronom «me» hauria de ser «le».

123 Es conserva la còpia de la carta que Díaz-Plaja li va enviar el 20 de setembre: «Querido Paco: Con el placer de siempre he atendido a tu recomendado Alberto Planes Surriol, hijo del Capitán de uno de tus buques y que por venir recomendado por ti nada había de temer. Espero ir a verte ya que la cuestión del Teatro Municipal de la que con tanto cariño hablaste con ocasión de nuestra última cena parece entrar en un período de gran fervor. Saluda a tu mujer en mi nombre y recibe como siempre un apretado abrazo de tu compañero y amigo», ibídem.

124 Rafael MANZANO, «Dialogar es necesario. Manuel Collado nos expone sus proyectos sobre el Teatro Municipal de Barcelona», Solidaridad Nacional, 21 set. 1949, 5; «¿Qué opina Vd.? El nuevo proyecto de Teatro de la Ciudad. ¿Tiene idea de lo que puede ser? ¿Dónde lo emplazaría? Marta Grau», El Correo Catalán, 26 oct. 1949, 6.

125 Vegeu R. Argelich \& Francisco Marsal, «El Teatro Municipal» 634 (1 oct. 1949): 2; «Un observador» 636 (15 oct. 1949): 2; F. MAYNES, «El Teatro Municipal» i J. VALLÉS Y PUJALS, «Hay que saber dar el salto» 642 (26 nov. 1949): 2; J.B. Pagés MARunY, «El solar de la Rambla» 644 (10 des. 1949): 5; S.B.R., «El Teatro Municipal» 645 (17 des. 1949): 12. 
-Ya tenemos teatro...

— ¡Qué más quisiera yo! —interrumpe.

-Supongámoslo. ¿Compañía o compañías?

-Es absolutamente absurdo pensar en esto cuando todavía no ha tenido realidad en el presupuesto.

-Pero si uno ya ha oído planes...

—No hay nada más de lo que he dicho. ${ }^{126}$

Ben aviat, Caralt es va desmarcar de la proposta específica de Díaz-Plaja, que la vinculava inicialment al Teatre Principal.

Dels objectius artístics del que hauria de ser el «Teatro de la Ciudad» 0 «Municipal», se'n va parlar poc, perquè es van diluir entorn d'altres aspectes d'organització i funcionament intern. Julio Coll a Destino va posposar la tria del local a la formació immediata d'una companyia estable amb intèrprets formats a l'Institut; un parell de decoradors, un director escènic i quatre o cinc obres en cartera:

Luego, más adelante, con un escenario Municipal inaugurado con bombo y platillos, la batalla estaría ya ganada y un equipo innominado de autores noveles vendría a restablecer la confianza sobre el futuro de nuestro teatro. De no hacerlo así, corremos el peligro de disponer de un magnífico edificio y un magnífico escenario sin nada que meterle dentro. A menos que, ante el fracaso, sirva dicho escenario para desarrollar conferencias en las que se insista en decir que nuestro teatro está en crisis. ${ }^{127}$

La proposta de Díaz-Plaja es basava en la recuperació de l'edifici del Teatre Principal per la seva tradició històrica i la seva ubicació en una zona de la ciutat que l'Ajuntament estava disposat a embellir per crear un complex espectacular inèdit a la ciutat. Com a «vocal del Consejo Superior

126 «Vd. Dirá... Luis de Caralt», Diario de Barcelona, 23 set. 1949, 2. Tanmateix, una setmana abans havia expressat: «Todas las solicitudes serán estudiadas y se escogerá aquella que sea más conveniente a Barcelona y a los intereses del municipio, a los que representamos», R. MANZANO, «Don Luis de Caralt nos habla del proyecto del Teatro Municipal», Solidaridad Nacional, 16 set. 1949, 6. Vegeu també SEMPRONIO, «Digresión deotoño. ¿Dónde construiremos el teatro municipal?», Destino 635 (8 oct. 1949):19.

127 «Municipalías», Destino 634 (1 oct. 1949): 19. 
del Teatro», Díaz-Plaja va redactar un article de síntesi a Destino ${ }^{128}$ en què explicava l'acollida de les seves declaracions a Solidaridad Nacional en altres diaris com La Prensa, El Correo Catalán, partidari del Teatre Principal, ${ }^{129}$ i el Diario de Barcelona, que apostava per un nou teatre en el solar del Novetats. ${ }^{130}$ Tractava també de la posició de Caralt, «mi buen amigo», el qual «con la prudencia del político destaca su independencia de criterio y renueva su voluntad de dotar a Barcelona de un Teatro que asegure a la ciudad un espectáculo de continuada dignidad espiritual. A él se lo debemos en todo caso. Y nadie dudará de su fervor de barcelonés y de amante de la cultura». Ampliava la informació sobre el que hauria de ser un teatre municipal, «al que yo llamaría más noblemente Teatro de la Ciudad», de què tractaria en la lliçó d'inauguració de curs de l'Institut del Teatre.

Efectivament, Díaz-Plaja va fer el discurs d'inauguració de curs, «Lo que ha sido y lo que podría ser el Teatro de la Ciudad», ${ }^{131}$ amb l'assistència de Juan Sedó Peris-Mencheta, diputat ponent de Cultura de la Diputació, i Arturo Sedó com a delegat de l'Estat en el Conservatori Superior de Barcelona, i sense que constés la presència de cap autoritat política de l'Ajuntament de Barcelona. ${ }^{132}$ En fer història, va esmentar la proposta del Teatre de la Ciutat, de Duran i Ventosa, i va reconèixer de nou que «no me gusta el adjetivo municipal». En aquesta ocasió, no es va estar d'explicar amb més detall l'ambiciós projecte que havia imaginat, del qual l'Institut

128 «La Alegría que pasa. Lo que podría ser el "Teatro de la Ciudad"», Destino 636 (15 oct. 1949): 17-18.

129 Ricardo SuÑÉ, «Estampas barcelonesas. Robreño y el Teatro... de Santa Cruz», El Correo Catalán, 28 set. 1949, 2. Vegeu també José ArTís, «Cuestiones de ahora. El "Teatro de la Ciudad" tiene una ficha», Liceo 52 (des. 1949): 37.

130 «Un día más. Sobre la creación de un Teatro Municipal», Diario de Barcelona, 20 set. 1949, 3.

131 Lo que ha sidoy lo que podría ser el Teatro de la Ciudad. Discurso pronunciado por el Director del Instituto del Teatro Dr. D. Guillermo Díaz-Plaja en el acto inaugural del curso 1949-195o (Barcelona: Instituto del Teatro de la Excma. Diputación Provincial. Conservatorio Superior de Barcelona, 1949).

132 La premsa va transcriure literalment la nota informativa que va enviar l'Institut del Teatre, en què es remarcava el següent: «Insistió el Sr. Díaz-Plaja que el no cree que su sugerencia sea la mejor ni que pueda ser la única, sino que lo que interesa es que el proyecto siga adelante y que Barcelona tenga el teatro que por su tradición cultural y amor a la dignidad escénica merece». Com a mostra, vegeu «Solemne inauguración del curso académico del Instituto del Teatro de la Diputación», $E l$ Noticiero Universal, 5 nov. 1949, 6; El Correo Catalán, 5 nov. 1949, 5. 
del Teatre hauria de ser el principal beneficiari, perquè el projecte era alguna cosa més «que una sala de espectáculos»:

El Teatro de la Ciudad debe contener, alrededor de un escenario y una platea, un núcleo de valores espirituales que acrediten la vinculación del arte dramático a la historia y al espíritu de la ciudad. En una palabra, el Teatro de la Ciudad de Barcelona debería contener, además del teatro propiamente dicho, los servicios de Archivo, Biblioteca y Museo de Teatro de Barcelona. ${ }^{133}$

La creació d'un Museu del Teatre apareix ja en el Proyecto, on es recordava que la Diputació havia comprat el Palau Güell, destinat a allotjar-hi un Museu de Teatre, com consta en les memòries del curs de la institució. ${ }^{134}$ Un museu, tanmateix, que no es va inaugurar fins al 1954, quan ja havia passat la febre del Teatre Municipal i Díaz-Plaja dividia la seva activitat professional entre Madrid, on havia estat nomenat director de la Real Escuela Superior de Arte Dramático, i Barcelona.

El 1949, el projecte d'utilització del Principal abastava també la creació d'un auditori per a l'Orquestra Municipal, una gran sala de conferències i una sala d'exposicions amb «la finalidad de poner al alcance del público los bocetos escenográficos, figurines, etc., de las obras representadas y cabría también (¿por qué no?) un rincón amable para las tradicionales marionetas». Si feia referència a les titelles és tal vegada perquè H.V. Tozer ${ }^{135}$ ho havia demanat en una de les cartes que es van publicar sobre el tema a Destino. ${ }^{136}$ Díaz-Plaja incloïa també la seva aposta per ubicar-hi una Escuela Oficial de Cinematografía «a espejo del Instituto de

133 Vegeu l'entrevista «Vd. dirá... Guillermo Díaz Plaja», Diario de Barcelona, 5 nov. $1949,2$.

134 Vegeu Bohigas, Memoria del curso 1944-45, 7-8; Picó, Memoria del curso 1948-49, 6, i Ramón Picó Capdevila, Memoria del curso 1949-5o (Barcelona: Instituto del Teatro. Diputación Provincial de Barcelona. Conservatorio Superior de Barcelona, 1950), 8.

135 Henry Vernon Tozer (1902-1992) es va installar a Barcelona el 1925. Entre altres activitats i manifestacions, va contribuir a donar a conèixer internacionalment el tipus català de titella de guant. Vegeu Josep A. MARTín, El teatre de titelles a Catalunya, Biblioteca Serra d'Or 197 (Barcelona: Publicacions de l'Abadia de Montserrat, 1998), 182-188 i el catàleg de l'exposició Harry V. Tozer (Barcelona: Diputació de Barcelona, Institut del Teatre, 1993).

136 «Cartas al Director. ¿Y las marionetas?», Destino 637 (22 oct. 1949): 2. Tozer recordava a DíazPlaja la tradició catalana de Juli Pi i els Quatre Gats. En la mateixa línia, vegeu la carta de J. ANGLÉs, «Teatro de marionetas», Destino 640 (13 nov. 1949): 2. 
Investigaciones y Experiencias Cinematográficas de Madrid», 137 i també la «necesaria creación de los servicios municipales de cinematografía educativa y se comprenderá con grandiosidad de lo que podría ser para Barcelona una Universidad del Espectáculo, única en el mundo». ${ }^{138}$

En aquestes alçades del relat, probablement el lector ha percebut el possible rerefons d'un conflicte d'interessos institucional i polític entre l'Ajuntament i la Diputació Provincial. O tal vegada d'una estricta topada d'interessos personals entre Caralt i Díaz-Plaja? O potser es tractava més aviat d'un conflicte global d'interessos institucionals, de política cultural i artística, i de motius personals? Fos el que fos, cap projecte específic de Teatre Municipal o de Teatro de la Ciudad no va arribar a quallar. ${ }^{139}$ Entremig hi va haver la vaga dels tramvies del març de 1951, el canvi d'alcalde i la renovació de la corporació municipal el 1951, sense la presència de Luis de Caralt. ${ }^{14^{\circ}}$ Un any més tard se'n va tornar a parlar. En aquesta ocasió, Artur Carbonell, sotsdirector de l'Institut, ${ }^{141}$ va insistir en la idea de constituir un teatre municipal amb la participació dels alumnes formats a la institució.

137 Es tracta d'una reiterada i arrelada aspiració de Díaz-Plaja, que volia emular els passos seguits per Joaquín de Entrambasaguas. Sobre els inicis de l'ensenyament del cinema a l'Estat espanyol, vegeu Eduardo RodríguEz MERCHÁN, «La enseñanza del cine en España: perspectiva histórica y panorama actual», Comunicar 29 (2007): 13-20.

138 Díaz-Plaja, «La Alegría que pasa...».

139 Com a resposta a les sollicituds reiterades de creació d'un Teatro de la Ciudad es va publicar una altra carta signada per Juventud, que anava en tota una altra direcció quant a les necessitats culturals de la societat: «Lo que necesita Barcelona y nosotros, la juventud, es el grandioso Teatro de la Televisión. A los veinticinco años de radio, nuestro mejor obsequio podría haber sido inaugurar Radio Televisión Barcelona que es lo que se merecía una emisora veterana y de tan rancio abolengo. ¿No será el pánico que produce este famoso adelanto de la ciencia, de tener en la mano el teatro, el cine, el futbol, los toros, etc., de que se esté rezagando durante demasiado tiempo? ¿Van a decir que el público dejaría de ir a los espectáculos? Vamos, señores, ayuden a la joven y graciosa Televisión y dejen al Teatro Municipal que repose en los archivos», «El Teatro Municipal», Destino 655 (25 febr. 1950): 9.

140 Vegeu Martí MARÍn i CORBERA, «L'Ajuntament de Barcelona, entre les dificultats electorals i l'aprovació de la Carta Municipal: de Simarro a Porcioles» i «La convocatòria de 1951: eleccions després d'una vaga», dins Els ajuntaments franquistes a Catalunya. Política i administració municipal, 1938-1979 (Lleida: Pagès editor, 200o), 265-270 i 270-273, respectivament.

141 Va ser nomenat el 18 de març de 1952 dins una reestructuració de la gestió del centre, generada per l'assumpció de Díaz-Plaja de la direcció de la Real Escuela Superior de Arte Dramático de Madrid. A partir d'ara, el director «será asistido de un Consejo directivo constituido por un Subdirector, un Regente de cada sección y el Secretario del Instituto». Com a regents van ser nomenats Josep Mestres Cabanes (Escenografia), Marta Grau (Declamació) i Joan Magrinyà (Dansa). Escrit adreçat 
Certament, Díaz-Plaja no va aconseguir tirar endavant el seu projecte de Teatro de la Ciudad, ${ }^{142} \mathrm{com}$ tampoc no es va anar més enllà de l'estricta constitució d'una Secció d'Estudis de Cinematografia, malgrat que se n'hagués aprovat la creació. Efectivament, el 30 d'octubre de 1950, tot partint com a referència de l'Instituto de Investigaciones y Experiencias Cinematográficas de Madrid, ${ }^{143}$ Díaz-Plaja va proposar formalment a la Comissió d'Educació, Esports i Turisme de la Diputació Provincial la creació «dentro del cuadro de enseñanzas del Instituto de una Sección que con el título de Estudios Complementarios de Cinematografía demuestre el interés de la Corporación Provincial por estos problemas y asimismo sirva de experiencia para la ordenación definitiva de las enseñanzas cinematográficas». ${ }^{144}$ En la reunió del 13 de novembre de 1950, la Comissió d'Educació, Esports i Turisme va informar favorablement de la proposta, ${ }^{145} \mathrm{i}$ el 17 de novembre es creava per decret «en este Instituto del Teatro la Sección de ESTUdios DE CINEMATOGRAFÍA». ${ }^{146}$

Acte seguit, el 3 de gener de 1951, Díaz-Plaja es va adreçar a Juan Sedó Peris-Mencheta, president de l'esmentada comissió per comunicar-li que «en virtud de la citada autorización y como vía de ensayo el próximo día 15 de enero empezarán a funcionar las clases correspondientes que, ajustándo-

el 27 de novembre de 1951 al diputat president de la Comissió d'Educació, Esports i Turisme de la Diputació (vegeu A-75/1, AAH).

142 Quatre anys després de la polèmica sobre l'habilitació o la creació d'un teatre municipal, tornava a aparèixer el tema a la premsa: «Hace ya años que se habla, en Barcelona, de crear un teatro municipal. La Ponencia de Cultura de nuestro Ayuntamiento dejó un día traslucir la idea, y tanto la Prensa como el público la acogieron con calor. Pero ha transcurrido bastante tiempo desde entonces. Y el proyecto ha quedado muerto antes de cristalizar. Hoy, al cabo de varios años, el teatro municipal sigue siendo lo que fue al principio: un hermoso sueño; tan hermoso que no puede, al parecer, convertirse en realidad. Con todo, la ejecución del viejo plan se ha hecho más urgente que nunca. Las perspectivas teatrales, en nuestra ciudad, no son brillantes. [...] No parece extraño, pues, en las actuales circunstancias, pedir al señor Ponente de Cultura de nuestro Ayuntamiento que nos hable de este teatro municipal. Que nos diga si, ahora que la ciudad lo precisa con urgencia, va a ser al fin constituido», Juan CANDILEJAS, «El Teatro. Barcelona: "Provincias”», Revista 44 (12-18 febr. 1953): 14.

143 Vegeu supra nota 134 .

144 A-75, AAH.

145 En un escrit del 22 de novembre de 1951 adreçat al diputat president de la Comissió, Esports i Turisme, Díaz-Plaja li demanava que «ordenase a la Sección de Arquitectura una inspección ocular base del presupuesto de las obras que se sugieren en el presente escrito para dictaminar después lo que se estime más conveniente», A-75, AAH.

146 AAH, A-75. 
se al Plan de Estudios del Instituto de Investigaciones y Experiencias Cinematográficas de Madrid, estarán constituidas por las siguientes asignaturas: "Historia del Cine”, “Caracterología aplicada al cine”, "Filmoliteratura” i "Interpretación cinematográfica”». Com a professorat designat per impartir les esmentades assignatures, a més de la participació del mateix Díaz-Plaja, es comptava amb María Luz Morales, Miquel Xirgu, Joan Francesc de Lasa, «quienes percibirán sus honorarios mientras dure la vigencia del actual Presupuesto con cargo a la Partida 608 ("Para conferencias, cursillos, etc.") del Instituto del Teatro». El 27 de gener, Sedó Peris-Mencheta informava favorablement de la proposta emesa per Díaz-Plaja. ${ }^{147}$ Malauradament, en la recerca que he fet tant en els fons del Centre de Documentació i Museu de les Arts Escèniques (CDMAE) de l'Institut del Teatre com en els de l'Arxiu General de la Diputació de Barcelona (AGDB), no he aconseguit trobar cap més informació sobre la possible articulació i desenvolupament d'una Secció d'Estudis de Cinematografia, de què tampoc es parla en les memòries corresponents als cursos 1950-1951 i 1951-1952. ${ }^{148}$

Finalment, i amb anterioritat a la inauguració del Museu del Teatre (1954), ${ }^{149}$ Díaz-Plaja va aconseguir que la seva experiència a l'Institut del Teatre servís per homologar i adaptar el seu estatus amb el de l'Escuela Superior de Arte Dramático de Madrid a partir de març de $1952 .{ }^{150}$ Efectivament, segons el Decret del 14 de març de 1952, publicat al BOE l'1 d'abril, «fueron separadas de los Conservatorios las enseñanzas de Declamación, pasando a constituir el Instituto del Teatro la Escuela Superior de Arte Dramático de Barcelona, debiéndose advertir que las únicas escuelas oficiales de Declamación existentes en España con la categoría

147 Q-992, AGDB.

148 Ramón Picó Capdevila, Memoria del curso 1950-51 (Barcelona: Diputación Provincial de Barcelona. Instituto del Teatro. Conservatorio Superior de Barcelona, 1951) i Ramón PiCó CAPDEVILA, Memoria del curso 1951-52, 6.

149 De la inauguració del Museu del Teatre al Palau Güell se'n parlava ja en el curs 1948-1949. Vegeu Picó, Memoria del curso 1948-49, 6, i també «Inauguración del Museo del Arte Escénico en el Palacio Güell», San Jorge 15 (jul. 1954): 94-96.

150 Decreto de 14 de marzo de 1952 por el que se separan las enseñanzas de Música y Declamación de los actuales Conservatorios, BOE 92, 1 abr. 1952. El 12 de desembre del mateix any el professorat de l'Institut va proposar al president de la Diputació Provincial que sollicités «a la superioridad sea concedida al Doctor Don Guillermo Díaz-Plaja Contestí, la Cruz de Alfonso el Sabio como recompensa a tan fructífera labor», A-75/10, AAH. 
de superiores son la Real Escuela de Arte Dramático de Madrid y el Instituto del Teatro (Escuela Superior de Arte Dramático)», com consta en una còpia de la Memoria explicativa de la labor del Instituto del Teatro, que Díaz-Plaja va remetre a Antonio Navarro Sedó, cap de la Secció de Premsa, Informació i Edicions de la Diputació Provincial de Barcelona el 3 desembre de $1953 \cdot{ }^{151}$

Amb el vistiplau de la Direcció General de Belles Arts i el ministre Joaquín Ruiz-Giménez, Díaz-Plaja va passar a assumir un paper protagonista en la reorganització de les Escoles d'Art Dramàtic de l'Estat, en ser nomenat «Delegado del Gobierno en la Real Escuela de Arte Dramático de Madrid y en el Instituto del Teatro de Barcelona, con las facultades pertinentes en las demás Escuelas de Arte Dramático de España, para que, previo el asesoramiento de los respectivos Claustros, elabore la propuesta de reorganización de sus enseñanzas, sometiéndola a la aprobación ministerial en el plazo máximo de seis meses.»152

Durant tres anys va organitzar a la Real Escuela de Arte Dramático de Madrid «la línea de actuación que debía conducir a la consecución del título de licenciatura para estos estudios y su estructuración universitaria. Nada de esto llegó a suceder, salvo la referencia en 1970, dieciocho años después, en la Ley de Educación (firmada por el ministro Villar Pallasí), que proponía la incorporación de los estudios de Música, Teatro y Bellas a la universidad española. Sólo Bellas Artes lo conseguiría en un discutido proceso de incorporación que comenzó en 1976».153 En qualsevol cas, com molt bé exposa Graells: «Díaz-Plaja havia estat l'instigador d'aquesta nova fórmula. El seu prestigi acadèmic, la seva habilitat a moure's pels ambients de la cultura oficial a Madrid i la bona relació amb els successius càrrecs polí-

151 A-70/18, AAH. Navarro Sedó era també el secretari de San Jorge, la revista de la Diputació Provincial de Barcelona creada i dirigida per Díaz-Plaja a partir de 1951.

152 Orden de 8 de abril de 1952 por la que se nombra a don Guillerno Díaz-Plaja y Contestí, Delegado del Gobierno en la Real Escuela de Arte Dramático de Madrid y en el Instituto del Teatro de Barcelona con las facultades inspectoras pertinentes en las demás Escuelas de Arte Dramático de España, BOE 112, 21 abr. 1952. Posteriorment hi va haver una rectificació de l'ordre del 8 d'abril, vegeu BOE 155, 3 juny 1952, 2477. Vegeu les declaracions de Díaz-Plaja, poc abans de la inauguració del curs 1952-1953 a Madrid, «La Vanguardia en Madrid. La Escuela de Arte Dramático va a comenzar a funcionar», La Vanguardia Española, 22 oct. 1952, 4.

153 Juanjo Granda, Historia de una escuela centenaria. RESAD (Madrid: Real Escuela Superior de Arte Dramático, 2000), 24. 
tics ja havien provocat el seu nomenament, el juny de 1949, com a vocal del Consejo Superior del Teatro. I ara, en formalitzar-se la nova ordenació dels ensenyaments teatrals, seria nomenat inspector de les Escoles d'Art Dramàtic de tot Espanya i delegat a la de Barcelona. A partir d'aquest moment s'accentuà l'absentisme del director de l'Institut, ja iniciat en anys anteriors amb viatges i gires de conferències per tot l'Estat i per Amèrica. En aquestes ocasions, era substituït pel professor més antic, o sigui Josep Mestres i Cabanes, però en decidir-se la creació del càrrec de sots-director, també el març de 1952, aquest correspongué al professor Artur Carbonell».154

\section{Coda}

El cant del cigne de Díaz-Plaja en relació amb la seva actuació i gestió en el si de la cultura catalana de postguerra es va produir molt abans que abandonés forçosament la direcció de l'Institut del Teatre el 1970. Ara bé, la història del funcionament de l'antiga Escola Catalana d'Art Dramàtic durant la postguerra només es pot comprendre en tota la seva totalitat $\mathrm{i}$ complexitat a partir del reconeixement de l'absoluta identificació que es va donar entre la institució i l'ambició i l'empremta personals de Guillermo Díaz-Plaja, especialment durant el primer franquisme.

Provinent de l'ambient cultural català de preguerra, senyalat per la seva condició de vençut, Díaz-Plaja va optar com tants altres per la carta de fer-se franquista amb totes les seves conseqüències. Prenent com a model Eugeni d'Ors, el seu mestre i un dels referents en els primers temps de postguerra, va procurar estar sempre molt amatent a les canviants palpitacions del temps a l'hora de dirigir i gestionar les activitats de l'Institut del Teatre. ${ }^{155}$ Tanmateix, malgrat la seva capacitat innegable

154 Guillem-Jordi Graells, L'Institut del Teatre..., 87. Vegeu també supra nota 138. Posteriorment, Díaz-Plaja, que ja era corresponent de la Real Academia Española de la Lengua, en va ser nomenat acadèmic numerari el 1967, i va dirigir també l'INLE (Instituto Nacional del Libro Español) entre 1966 i 1970. D’altra banda, el 1961 va ser nomenat membre numerari de la RABLB, que era dirigida en aquell moment pel seu mestre Jordi Rubió i Balaguer.

155 Vegeu què deia sobre Ors el 1968: «La generació nostra, la generació que va néixer a la vida cultural catalana vers els anys 25, 26, 27, va trobar-se davant un gran esvoranc, gairebé davant un abisme, del qual nosaltres només coneixíem un vessant. Se'ns parlà d'un home absent, d'un home fugitiu, potser d'un traïdor. D'una manera instintiva, un grup d'universitaris que aleshores, com dic, 
d'acomodar-se a les circumstàncies, producte d'un excellent coneixement personal de l'entorn polític i cultural, i de la seva habilitat a l'hora d'activar les seves estratègies i propostes culturals, no sempre es va sortir amb la seva, com en són exemple els projectes del Teatro de la Ciudad i la Secció d'Estudis de Cinematografia. Per què no va reeixir-hi? Des de la perspectiva actual, aquests dos projectes frustrats mostren segurament els límits de l'actuació pública de Díaz-Plaja, la seva vulnerabilitat política, la pèrdua d'un determinat protagonisme de què havia gaudit fins a aquell moment en l'àmbit català, i probablement també una ambició personal, que més d'un devia considerar excessiva, entre altres qüestions. Efectivament, a banda de la direcció de la Real Escuela Superior de Arte Dramático de Madrid en la primera meitat dels cinquanta, i al marge també dels viatges per les Amèriques i un ampli desplegament d'activitats culturals en el sector privat, Díaz-Plaja va anar perdent progressivament incidència i pes polític específic en les cultures catalana i espanyola, que van emprendre una profunda renovació a partir de la segona meitat dels cinquanta, de la qual ell va quedar al marge.

Paradoxalment, pocs anys abans del cessament com a director de l'Institut del Teatre va aconseguir un doble reconeixement institucional en el marc cultural espanyol: acadèmic numerari de la Real Academia Española de la Lengua i director de l'INLE, que venien a completar en l'àmbit català la seva condició de membre numerari de l'Acadèmia de Bones Lletres. La dinamització i reactivació de les cultures catalana i espanyola, però, es movien per unes altres vies i es regien també ja per uns altres paràmetres artístics, estètics i ideològics, que globalment s'allunyaven dels defensats per Guillermo Díaz-Plaja. Vet aquí la qüestió.

\footnotetext{
començava la seva feina, va sentir-se atret, justament, per aquesta figura vexada, tot considerant que, no havent pres part a la batalla, i no havent-se vinculat a les faccions en lluita, no tenia per què acceptar les posicions preses per un dels sectors belligerants. El nostre "orsianisme" va néixer, doncs, d'aquesta rebel curiositat que, congriada d'un sentiment discret, però fortíssim, de justícia, temptà d'establir, almenys, les dades necessàries per a un judici. No ens en vam penedir, car al llarg d'uns quants anys aquesta actitud va obtenir aquells fruits d'amistosa gentilesa que Xènius solia donar quan els anys havien amorosit el tarannà- als seus amics», La defenestració de Xènius (Barcelona: Editorial Andorra, 1968), [12].
} 


\section{Annexos}

$1^{156}$

CONVOCATORIA DEL CONCURSO OPOSICIÓN PARA CUBRIR LA PLAZA DE DIRECTOR DEL INSTITUTO DEL TEATRO DE LA DIPUTACIÓN PROVINCIAL

En cumplimiento de lo acordado por la Comisión Gestora de la Diputación Provincial, en sesión de 28 de marzo último, se anuncia concurso libre para la provisión de la plaza de Director del Instituto del Teatro, con sujeción a las siguientes

BASES

$1^{\mathrm{a}}$.- Podrán tomar parte en el concurso oposición todos los españoles mayores de 25 años que acrediten poseer los conocimientos del arte teatral así como los méritos alcanzados en el cultivo del mismo, o la práctica en su enseñanza que les hagan aptos para ejercer la dirección del servicio y reúnan además las condiciones siguientes:

a) Ser ciudadano español.

b) Estar en pleno goce de sus derechos civiles.

c) No estar sujeto a inhabilitación para el ejercicio de cargos públicos, o para puestos de confianza.

d) Haber observado buena conducta adhesión y carecer de antecedentes penales.

e) Acreditar la más absoluta adhesión al Glorioso Movimiento Nacional.

$2^{\mathrm{a}}$.- Los aspirantes presentarán sus instancias dirigidas al Excmo. Sr. Presidente de la Corporación ajustadas a las prescripciones vigentes y por el término de 15 días hábiles a partir del siguiente inclusive a la fecha de la publicación de esta convocatoria en el Boletín Oficial del Estado, acompañando los documentos siguientes:

a) Certificado del acta de nacimiento, debidamente legalizada. 
b) Cédula personal que se devolverá al interesado después de hechas las anotaciones correspondientes.

c) Certificado del registro central de penados y rebeldes que acredite no haber sufrido condena ni estar declarado en rebeldía.

d) Certificado de adhesión al Glorioso Movimiento Nacional expedido por la Delegación Provincial de Información e Investigación de FET y de las JONS. O bien por alguna Autoridad o dos avales de suficiente garantía; o carnet de militante en dicha Organización del Movimiento.

e) Cuantos documentos se estimen necesarios en demostración de los méritos y restantes condiciones alegadas.

f) Documento acreditativo de la situación militar del aspirante.

Las instancias serán presentadas en el registro General de la Diputación provincial por todo día de terminación del plazo de admisión. Una vez terminado este plazo, se publicará en el Boletín Oficial de la Provincia, la lista de los admitidos y el local y fecha que darán comienzo a los ejercicios antes de comenzar los cuales, serán sometidos a un reconocimiento facultativo que acredite su aptitud física para el cargo.

$3^{\mathrm{a}}$.- El tribunal o Jurado que ha de fallar el presente concurso oposición y elevar la propuesta de nombramiento correspondiente, estará integrado por un Presidente que será el Iltre. Sr. Diputado Ponente de Cultura; Don Fernando Valls y Taberner, Director de la Escuela de Bibliotecarias y Académico de la Real academia de Buenas Letras; Don Arturo Masriera, miembro de la Real Academia y Bellas Artes de San Jorge; un representante de la Sociedad de Autores y un representante del Sindicato Teatral. Actuará de Secretario, el Jefe de la Sección de Cultura de esta Diputación Provincial. $4^{\mathrm{a}}$.- El Tribunal podrá llamar a los Sres. Concursantes invitándoles a que verbalmente amplíen los conceptos de méritos que hayan alegado y expongan en términos generales los planes o métodos que se propongan aplicar en el desempeño de su cargo en caso de obtener el nombramiento. 
$5^{\mathrm{a}}$-- Para el fallo del concurso oposición el Tribunal apreciará libremente los méritos y circunstancias de los aspirantes, teniéndose en cuenta lo dispuesto por la Ley de 25 de Agosto de 1939, sobre provisión de plazas.

$6^{\mathrm{a}}$.- Se considerarán méritos especiales para establecer preferencias entre los concursantes:

a) Ser militante de FET y de las JONS.

b) Poseer una destacada personalidad artística públicamente reconocida.

c) Haber sido distinguido con premios o menciones honoríficas durante el ejercicio profesional.

d) Haber sido profesor de conservatorio o entidad análoga relacionados con el teatro.

e) Poseer un título académico.

$7^{\mathrm{a}}$.- En el caso de igualdad de méritos entre los concursantes el Tribunal podrá someterlos a una doble prueba consistente en la redacción de una memoria descriptiva de la reorganización del Instituto y en la explicación de una lección de la especialidad teatral que escoja el concursante.

$8^{\mathrm{a}}$.- El concursante que obtenga la plaza vendrá obligado a desempeñar una de las cátedras del Instituto, determinada de acuerdo con las condiciones del concursante a elección de éste y confirmación por el Tribunal y al sueldo total de que disfrutará la plaza de Director-profesor será de 9.00o Ptas. anuales.

$9^{\text {a }}$ - Los admitidos a la oposición abonarán en concepto de derechos la cantidad de 25 pesetas, una vez declarados útiles.

10.- El Tribunal queda autorizado para resolver cuantas incidencias surjan por motivo de este concurso-oposición, que no estén previstas en esta convocatoria.

Barcelona, 18 de abril de 1941.

[Signatura illegible]. 
EXTRACTO DEL EXPEDIENTE PRESENTADO POR EL CATEDRÁTICO DON GUILLERMO DÍAZ-PLAJA, EN EL CONCURSO OPOSICIÓN PARA PROVEER LA PLAZA DE DIRECTOR DEL INSTITUTO DEL TEATRO.

\section{LA OBRA REALIZADA}

A los pocos meses de la liberación de Barcelona el Doctor Díaz-Plaja fue nombrado Director interino de esta institución.

En los dos años escasos de su actuación al frente del citado organismo, el Instituto del Teatro se ha incorporado al nuevo espíritu, ha duplicado su matrícula, ha inaugurado una biblioteca pública especializada, ha fundado un museo de nueva organización, ha montado el nuevo archivo, ha creado seis cátedras nuevas, (dos de las cuales son regentadas gratuitamente por el actual director), ha desarrollado dos importantes ciclos de conferencias en los que han actuado las figuras más prestigiosas de nuestro mundo literario y teatral y ha presentado al público con éxito rotundo de prensa y de público representaciones de teatro español clásico y moderno. Aparte de ello se han llevado a cabo importantes obras de instalación y reorganización de servicios.

\section{MÉRITOS PERSONALES}

Además de poseer, naturalmente, los méritos previos para tomar parte en el Concurso, concernientes a edad, naturaleza, depuración política sin sanción, posee el concursante, de manera evidente y extraordinaria la totalidad de los méritos que se estiman como méritos especiales.

a) Pertenece a Falange Española Tradicionalista y de las JONS.

b) Posee una destacada personalidad. Su obra literaria abarca unos treinta volúmenes, una gran parte de los cuales se ocupan de historia y crítica teatral. La crítica española ve en la obra del Doctor Díaz-Plaja una de las guías más sobresalientes para la juventud intelectual de nuestra Patria 
c) Ha obtenido constantemente premios y calificaciones extraordinarias. He aquí los principales: Primer Premio Nacional de Literatura (1935), Premio extraordinario de Filosofía y Letras, Premio Rivadeneyra, Premio Único para la Crítica Teatral, Grado de Doctor con Sobresaliente, mayoría de sobresalientes y matriculas de honor en sus expedientes académicos. Número uno de sus oposiciones.

d) Ha dirigido durante dos años el Instituto del Teatro de la Diputación Provincial. Además ha sido Director, durante los cursos 193334, de la Sección Dramática del Conservatorio del Liceo, reorganizando y tomando parte en la tarea docente. Es asesor literario de las falanges teatrales del Sindicato Español Universitario, con las que ha realizado frecuentes campañas de revalorización de nuestros clásicos y dirige el cuadro escénico del Instituto Jaime Balmes.

e) Títulos académicos: Catedrático Numerario, por oposición directa, de Literatura en el Instituto Jaime Balmes y confirmado sin sanción después de su reglamentaria revisión, al liberarse la Ciudad, Doctor en Filosofía y Letras Sección de Letras, Licenciado en la misma Facultad, Maestro Nacional y Bachiller. 
Luys Santa Marina, Consejero Nacional de Falange; Tradicionalista y de las JONS, presidente del Ateneo Barcelonés, director de Solidaridad Nacional.

\section{DECLARO:}

Que mantengo desde hace muchos años relaciones literarias y de amistad con el catedrático del Instituto «Balmes», Camarada Guillermo Díaz-Plaja, lo que me permite afirmar con pleno conocimiento:

$1^{\mathrm{o}}$.- Que su labor literaria ha sido y es digna de todo encomio desde el punto de vista de la España Nacional, ya que constituye una exaltación constante de los valores espirituales de nuestra literatura. Así, por ejemplo, en sus libros «Introducción al Estudio del Romanticismo Español» (obra galardonada con el Premio Nacional de Literatura), «La Poesía Lírica Española», «Síntesis de la Literatura Española», «Garcilaso y la poesía española», etc. $2^{\mathrm{o}}$.-Que esa labor debe estimarse como más meritoria en contraste con el medio intelectual en que hubo de moverse el Camarada Díaz-Plaja. Puede afirmarse que aun en las ocasiones en que utilizó el catalán como vehículo de expresión (posteriormente sólo en castellano ha publicado sus libros) procuró combatir la cerrazón intelectual predominante en Cataluña dando a conocer las grandes figuras de la literatura española.

$3^{\circ}$.-Que asimismo aprovechó todas las coyunturas de su vida docente para dar a su labor un sentido afirmativo e imperial, como cuando recogía y publicaba las huellas españolas del Mediterráneo Oriental, o cuando en el Crucero Universitario a Centro y NorteAmérica, llevaba la voz cultural de España en fervientes actos de propaganda patriótica. 
$4^{0}$.- Que desde su primer número (en el que publicó el artículo inicial) ha venido colaborando en la revista falangista Azor que desde 1932 venía publicándose en Barcelona bajo mi dirección.

$5^{\circ}$.-Que por todo ello, por los antecedentes familiares que en él concurren, por contar con un caído por Dios y por España entre sus deudos más próximos y por la actitud en que se ha mantenido durante el período de la dominación roja en Cataluña, el Camarada Guillermo Díaz-Plaja puede ser considerado como plenamente afecto a la Causa Nacional, a la que viene prestando su colaboración entusiasta.

Y para que conste donde fuere menester, firmo la presente Declaración en Barcelona a 14 de octubre del Año de la Victoria. SALUDO A FRANCO ARRIBA ESPAÑA LUYS St ${ }^{\mathrm{a}}[$ sic] Marina 
JUAN RAMÓN MASOLIVER MARTÍNEZ, Doctor Electo en Filosofía y Letras, Licenciado en Derecho, Jefe Territorial de Propaganda de Cataluña; declaro que conozco al Profesor Guillermo Díaz Plaja desde 1926, teniendo desde entonces estrecha y continuada relación con él por haber sido condiscípulos en la facultad de Filosofía y Letras, haber opositado juntos los premios extraordinarios de la Licenciatura de Letras y Rivadeneyra, y colaborar en el mismo movimiento literario y en las mismas revistas durante aquella época que va de la Dictadura al último año de la Monarquía. Pasado el firmante al extranjero en 1930, siguió manteniendo relación estrecha con el citado profesor por encuentros en Barcelona, Madrid y Roma, por correspondencia epistolar y por seguir toda su producción periodística y literaria, así como su labor académica, hasta julio de 1936.

Durante el período de la guerra, el firmante en su calidad de director, primero, de Radio Verdad y luego de Jefe del Departamento de Propaganda de Ocupación y para la Zona no Liberado [sic] del Ministerio de la Gobernación, tuvo también noticias de los azares corridos [sic] por dicho señor Díaz Plaja. Y a partir de la liberación de Barcelona ha reanudado el contacto directo con el mismo. Por todo lo cual puedo declarar, en conciencia, lo siguiente:

$1^{\circ}$.- Que el Sr. Díaz Plaja, por su ambiente familiar, por su educación y convicciones, jamás se ha apartado un ápice de las ideas que informan nuestra Causa.

$2^{\circ}$.- Que desde sus primeras producciones literarias (un folleto y un libro sobre Rubén Darío) mostró siempre gran atención a la obra de los grandes poetas castellanos y contra el ambiente localista que por aquellos años imperaba en Barcelona, siendo el mejor intérprete de la altura castellana contemporánea en esta Ciudad y colaborador asiduo del periódico falangista Azor (Barcelona) y de la Gaceta Literaria y Cruz y Raya de Madrid. Su labor hispánica tuvo mucho campo en los cruceros universitarios a Levante y a las Américas, dando 
conferencias a los universitarios viajeros y en las mejores tribunas de los países; así como en la colaboración literaria que ha sostenido en periódicos y revistas hipanoamericanas.

$3^{\circ}$.- Que no sabe haya militado jamás en partido político alguno, pero sí puede atestiguar sus convicciones morales y patrióticas a fuer de hijo de un dignísimo militar español por quien pasó sus años juveniles en África, y por haber asistido con él a las reuniones de los primeros falangistas de Barcelona.

Y para que conste a los efectos oportunos, firmo el presente en Barcelona a diez y seis de Octubre de mil novecientos treinta y nueve. Año de la Victoria.

El Jefe Territorial de Propaganda

Firmado: Juan Ramón Masoliver

SALUDO A FRANCO:

¡ARRIBA ESPAÑA! 
5 Certificat de Fernando Valls y Taberner ${ }^{160}$

DON FERNANDO VALLS Y TABERNER, Director del Archivo de la Corona de Aragón, Catedrático de Universidad,

CERTIFICO: Que habiendo sido elegido, en 1933, Presidente de la Junta del Conservatorio del Liceo de Barcelona, procedí a la reorganización de la Sección de Arte Dramático, para lo cual requerí la colaboración del Catedrático de Literatura Don Guillermo Díaz-Plaja por estimar concurrían en él las circunstancias más favorables para el desempeño de dicha labor. Guillermo Díaz-Plaja, a quien por entonces no conocía personalmente, se hizo eco de nuestro requerimiento y dirigió los trabajos de la Sección de Arte Dramático del Conservatorio del Liceo, no sólo explicando clases teóricas de historia y técnica del teatro, sino dirigiendo y orientando las cátedras de declamación, impostación de voz, orientación de repertorios, etc., todo ello a plena satisfacción de la Junta Directiva, hasta que, a petición propia, cesó en sus funciones en septiembre de 1934.

Y para que conste a los efectos que hubiere menester firmo el presente certificado en Barcelona a catorce de julio de mil novecientos treinta y nueve.

Fernando Valls Taberner

16o Q-569/48, AGDB. 
DECRETO DEL 26 DE ENERO DE 1944 POR EL QUE SE CREA EN BARCELONA UN CONSERVATORIO SUPERIOR DE MÚSICA Y DECLAMACIÓN

El Decreto de quince de junio de mil novecientos cuarenta y dos, que se consideraba, en su preámbulo, como punto de partida para la reorganización de todos los Conservatorios españoles, señalaba en su tercera disposición transitoria la posibilidad de que la Escuela Municipal de Música y el Conservatorio del Liceo de Barcelona se asimilasen a determinados tipos de Conservatorio oficial. Un estudio más detenido de la cuestión aconseja ampliar esta posibilidad a otros organismos, incorporando su indudable eficacia pedagógica a la obra general del Estado, sin merma de aquellas características que han motivado su prestigio.

En virtud de lo expuesto, a propuesta del Ministerio de Educación Nacional y previa deliberación del Consejo de Ministros.

\section{DISPONGO:}

ARTÍCULO PRIMERO.- Se crea en Barcelona un Conservatorio Superior de Música y Declamación.

ARTÍCULO SEGUNDO.- Las funciones docentes del Conservatorio Superior de Música y Declamación de Barcelona serán asumidas de modo exclusivo: para la enseñanza de la Música, por la Escuela Municipal de Música y el Conservatorio del Liceo, y para las enseñanzas de Declamación y Danza, por el Instituto del Teatro de la excelentísima Diputación Provincial de Barcelona.

ARTÍCULO TERCERO.- Estas instituciones quedan obligadas a establecer el mismo cuadro de estudios de los Conservatorios del Estado.

Aprobados estos estudios, los alumnos podrán solicitar la expedición del título correspondiente con plena validez oficial.

ARTÍCULO CUARTO.- Las instituciones expresadas continuarán con el mismo régimen interior docente, académico y administrativo que hoy poseen y bajo el patronato, dirección y mecenazgo de las Corporaciones $\mathrm{u}$ organismos que actualmente las dirigen.

161 BOE 47, 16 febr. 1944, 1382. 
ARTÍCULO QUINTO.- El Estado nombrará un Delegado permanente en el Conservatorio de Barcelona, cargo que recaerá en una elevada personalidad destacada por su prestigio o por su amor al arte, y cuya misión consistirá en inspeccionar los estudios de las referidas instituciones y velar por el perfecto y normal desarrollo de la enseñanza.

ARTÍCULO SEXTO.- El Estado se reserva el derecho a designar uno o más Catedráticos numerarios del Conservatorio oficial que intervengan en los exámenes de fin de curso de Barcelona.

ARTÍCULO SÉPTIMO.- Para las cuestiones de carácter general del Conservatorio funcionará una Junta constituida por los Directores de las instituciones que lo integran, presidida por el Delegado de las instituciones que lo integran, presidida por el Delegado permanente, y en la que actuará de Secretario el de menos edad. Esta Junta tendrá como misión la coordinación de las tareas respectivas de cada una de las entidades, las relaciones del Conservatorio con el Estado y la propuesta de solución para los problemas generales que la vida del nuevo Centro plantee.

ARTíCULO OCTAVO.- La partida que figura en el Presupuesto del Ministerio de Educación Nacional bajo el epígrafe «Para la incorporación de los Conservatorios de Música y Declamación de Barcelona» será librada a nombre del Delegado permanente, a fin de ser distribuida por partes iguales entre las instituciones que integran el Conservatorio, en concepto de subvención, e invertida y justificada por los respectivos Directores en las atenciones de las correspondientes enseñanzas.

ARTíCULO NOVENO.- El Ministro de Educación Nacional dictará cuantas Ordenes considere necesarias para la aplicación de lo establecido en los artículos anteriores.

Así lo dispongo, por el presente Decreto, dado en Madrid a veintiséis de enero de mil novecientos cuarenta y cuatro.

El Ministro de Educación Nacional, FRANCISCO FRANCO JOSÉ IBÁÑEZ MARTÍN 


\section{PROYECTO DE UN «TEATRO DE LA CIUDAD» CONSIDERACIONES GENERALES}

1.- UN AMBIENTE INDUDABLE.- $\mathrm{Al}$ redactar el presente proyecto de un «Teatro de la Ciudad» partimos de un estado de ánimo evidente en los mejores espíritus de Barcelona. No pasa día sin que a través de la prensa, de la radio, y de las conversaciones particulares no se alce el clamor de la decadencia de nuestro teatro; puede decirse que representa un auténtico problema espiritual ciudadano.

La avalancha del cine y la cada vez más escasa educación literaria de nuestro público empuja a los autores a crear un teatro en el que la plebeyez y la pornografía se entregan a la muchedumbre halagándola en sus más torpes debilidades.

2.- NECESIDAD DE UN TEATRO LIBERADO DEL INFLUJO DE LA MASA.Eliminando por "inútil" una exposición de los problemas generales de la escena contemporánea, es evidente que está en el ánimo de todos la necesidad de realizar un esfuerzo supremo para dotar a nuestro teatro de unas garantías intelectuales y morales que le conviertan en lo que ha sido siempre: un auténtico espejo de inteligencia y de cultura.

Pero esas garantías no pueden ponerse en práctica mientras no las apoye una garantía económica. Un mecenazgo oficial o particular debe servir a este gran esfuerzo de educación ciudadana.

3.- MISIÓN DE LA PONENCIA DE CULTURA.- La Ponencia de Cultura del Excmo. Ayuntamiento de Barcelona encuentra esta cuestión en un estado de extraordinario abandono. En lo que hace referencia a la educación espiritual de los ciudadanos la Ponencia anterior orientó sus esfuerzos hacia la Música y hacia los Museos. Queda totalmente inatendida la cuestión del Teatro. Esta cuestión Madrid - con el apoyo del Estado- la ha resuelto ya. Barcelona no puede quedar atrás. La Ponencia de Cultura

162 A70-42, Arxiu Administratiu del CDMAE de l'Institut del Teatre. 
de su Ayuntamiento es la fuerza indicada para llevar a cabo esta gran labor. Debe crear de una vez para siempre el «Teatro de la Ciudad».

\section{EL TEATRO DE LA CIUDAD}

1.- ANTECEDENTES. SOLUCIONES POSIBLES.- Si el Excm. Ayuntamiento de Barcelona se propone resolver este ya viejo problema que tanto afecta al nivel cultural de nuestra ciudad se encuentra ante tres soluciones

$1^{a}$.- Arriendo de un teatro.- Cabe la simple tarea de tomar en arriendo un determinado teatro y facilitarlo en determinadas condiciones a los grupos teatrales que previo concurso vayan ofreciendo programas de más alta calidad artística.

Esta solución no ofrece garantía ninguna por su falta de estabilidad y por no caracterizar de una manera enérgica la gestión municipal que ha de llevar a término un verdadero "Teatro de la Ciudad".

$2^{\mathrm{a}}$.- Construcción de un teatro.- Podría resucitarse el famoso concurso que, embargado por la misma preocupación nuestra, convocó el Ayuntamiento de Barcelona en 1921, lo que dio lugar a una violentísima polémica por considerarse que no habían sido atendido todos los factores necesarios.

Esta segunda solución es también poco viable. Levantar un gran teatro de planta supone un esfuerzo colosal y el solar que el Estado ha destinado (Vía Layetana frente al Fomento del Trabajo Nacional) no parece el más indicado para atraer al público. El concurso de proyectos provocaría una nueva polémica y la ejecución de las obras demoraría enormemente la realización de nuestro deseo.

$3^{\mathrm{a}}$-- Salvación de un teatro.- Queda una tercera posibilidad. A mi juicio la más interesante y viable: se trataría de devolver a la ciudad el edificio que desde el siglo XVII constituye su teatro más representativo: El Teatro de la Santa Cruz, hoy Principal. 
2.- VENTAJAS DE ESTA TERCERA SOLUCIÓN.- De estas tres soluciones la que hemos enunciado en tercer lugar ofrece tan extraordinario interés que merece nuestro más entusiasta apoyo. He aquí las razones que motivan nuestra vehemente adhesión a este proyecto.

$1^{\mathrm{a}}$.- Tradición.- Es emocionante señalar en primer término el dato de que el edificio que nosotros señalamos es el más antiguo teatro de Europa que se mantiene invariable en su sitio desde el siglo XVI hasta hoy. Efectivamente data de 1587 una orden de S. M. el rey Felipe II en la que a petición de los administradores del Hospital General de la Ciudad se les concedía el privilegio de organizar representaciones las cuales desde el primer momento tenían lugar en el local que el Hospital tenía en la Rambla.

Durante los siglos XVII y XVIII este teatro que ya se denomina Principal de Barcelona continúa sus representaciones y en esta última centuria se inician las representaciones de ópera dando lugar a una afición entusiasta que durante el siglo XIX se enfrenta con el Liceo en las famosas discusiones de «liceístas» $\mathrm{y}$ «cruzados».

En lo que va de siglo el local repetidas veces incendiado y reconstruido desciende de categoría para servir espectáculos procaces y populacheros. Es un deber de Barcelona devolver a este edificio su nobilísima tradición. No somos nosotros los primeros en intentarlo: en 1915 el Ayuntamiento de Barcelona tenía ya en marcha todos los trabajos inherentes a la municipalización del Teatro Principal, cuando desgraciadamente el incendio que devastó el edificio en el mismo año dio al traste con todo el proyecto.

$2^{\mathrm{a}}$ - - Emplazamiento.- Como hemos indicado por espacio de cerca de cuatro siglos el Teatro Principal se mantiene en su sitio que por eso se denomina "pla de les Comedies" y actualmente Plaza del Teatro.

Notemos en primer término que el local es extraordinariamente céntrico; a doscientos metros del Gran Teatro del Liceo lo que garantiza la afluencia de público de toda clase y en un lugar tradicionalmente dedicado al teatro.

La dignificación de este edificio coincidiría por otra parte con lo que pudiéramos llamar política de dignificación del casco antiguo de Barcelona y especialmente de las Ramblas. Las instalaciones de la 
«Virreina» en la parte alta y del Museo Marítimo en su final son datos bastante expresivos. Si se tiene en cuenta la gran vía que ha de cruzar por detrás del edificio uniendo las Atarazanas y la calle de Muntaner se comprenderá que vale la pena culminar todas estas mejoras con la del edificio que nos interesa. Recuérdese que a pocos metros del primero se encuentra por otra parte el Palacio Güell de la calle Nueva de la Rambla en el que la Diputación Provincial de Barcelona va a inaugurar justamente el Museo del Arte Escénico dependiente del Instituto del Teatro.

$3^{\text {a }}$ - Adaptabilidad.- Nos encontramos en primer término con la existencia de un cuerpo ya edificado, de líneas nobilísimas, cuya belleza resaltará cuando se eliminen de la fachada los cartelones que la afean.

En su interior existe el local fundamental para nuestro objeto consistente en un teatro amplio, elegante y cómodo al que una reforma decorativa dotará de la severa elegancia que debe poseer el «Teatro de la Ciudad».

Pero la amplitud del local es de tal dimensión que cabría instalar en los aledaños del teatro todo un conjunto de servicios que pudiesen hacer de la casa un especie de universidad del arte dramático. En primer término las oficinas de la Delegación Municipal para el «Teatro de la Ciudad»; un auditorio con sala de conciertos y conferencias que Barcelona necesita urgentemente (en todo caso las actuaciones de la Orquesta Municipal deberían tener lugar de ahora en adelante en el «Teatro de la Ciudad»); una sala de exposiciones y una biblioteca especializada.

Creemos sinceramente que al Instituto del Teatro de la Diputación Provincial que no posee edificio propio se sentiría dichoso de incorporarse a este centro de estudios de teatro aproximándose así a su Museo del Arte Escénico de la calle Nueva de la Rambla.

5.- POSIBILIDAD DE ADQUISICIÓN.- Veamos ahora las extraordinarias circunstancias por las que atravesamos en estos momentos en relación al proyecto que estamos formulando. 
$1^{a}$.- Una coyuntura única.- En este momento se da la rara y feliz coincidencia de que el teatro «Principal Palacio» habitualmente arrendado ha terminado el contrato anterior y está por lo tanto libre de inquilinos. Nótese que sin esta circunstancia única no podría ni siquiera hablarse del presente proyecto puesto que con el teatro arrendado sería tal el cúmulo de problemas que habrían de plantearse que nos haría desistir de toda proposición.

Téngase en cuenta que la propiedad del edificio, en un rasgo de altruismo ciudadano ha paralizado varias propuestas de arrendamiento ante la posibilidad de que la adquisición por parte del $\mathrm{Mu}$ nicipio dé al inmueble el decoro definitivo que por su tradición merece. El Ayuntamiento sabrá reconocer en su día el valor de esta prueba de ciudadanía que ofrece la propiedad del edificio de que estamos hablando.

$2^{\mathrm{a}}$.- Un precio razonable.- Nos proponemos demostrar ahora que el precio que ha sido solicitado para la venta del edificio es un precio absolutamente razonable y que en modo alguno representa un gasto inútil puesto que aparte los valores históricos que se salvan y la labor educativa que se acomete, el desembolso ofrece la ventaja de poseer una rentabilidad absolutamente normal con lo que da a la inversión el carácter de un gasto reproductivo.

Es interesante hacer notar esta posibilidad ya que otras adquisiciones municipales aparentemente más económicas son casi totalmente improductivas a las Cajas municipales. En cambio un estudio solamente superficial de las posibilidades económicas del edificio del Teatro Principal permiten asegurar que el Ayuntamiento percibiría como mínimo un cuatro por ciento anual de la cantidad invertida con lo que los servicios inherentes al «Teatro de la Ciudad» quedarían totalmente cubiertos por las rentas del edificio quedando un importante remanente para ingresar anualmente en las Cajas municipales. 


\section{ANTEPROYECTO DE ACTUACIÓN}

1.- ORGANIZACIÓN ADMINISTRATIVA.- El «Teatro de la Ciudad» debe pertenecer al patrimonio de la ciudad y ser regido por el Ayuntamiento de Barcelona. Los organismos rectores de esta nueva institución deberán ser los siguientes:

a) El señor Teniente de Alcalde delegado de Cultura asesorado por la Comisión de Cultura que ejercería las funciones rectoras supremas en su carácter de orientación política y cultural.

b) Un Delegado del Ayuntamiento que asumiría la delegación de los servicios y sería el responsable técnico del nuevo organismo.

c) Un consejo asesor de la Delegación en el que estarían representados elementos de la profesión teatral, de la prensa y de los centros docentes de Barcelona.

d) Un departamento técnico administrativo a las órdenes directas del Delegado.

2.- BASES DE ACTUACIÓN.- Las informaciones recogidas en relación con otros teatros subvencionados aconsejan prescindir en absoluto de lo que se llama compañías titulares. Estas compañías crean un pernicioso funcionamiento y son en absoluto rechazables.

3.- ORGANIZACIÓN DE LAS TEMPORADAS OFICIALES.- Partiendo de la inexistencia de una compañía titular creo que lo más aconsejable sería establecer durante la temporada varios concursos entre compañías. Estos concursos nos traerían las siguientes ventajas:

a) Estimular las agrupaciones profesionales para que dignifiquen los repertorios.

b) Facilitar la actuación de las compañías subvencionadas de Madrid.

c) Evitar el dogal económico que supone la compañía titular.

d) Organizar representaciones oficiales de teatro escolar.

e) Hacer posibles las alternativas de géneros de suerte que podrían cultivarse sucesivamente teatro clásico y teatro de vanguardia; teatro castellano y teatro catalán; compañías extranjeras; teatro lírico. 
Asimismo dentro de las temporadas oficiales deberían figurar los conciertos de la Orquesta Municipal y otras orquestas y orfeones locales, las conferencias, exposiciones, etc.

Todas estas actividades constituirían la temporada oficial que ocuparía los meses más escogidos del año y que estaría regida por un riguroso criterio de selección estética, intelectual y moral.

Si a la Corporación le pareciera oportuno podrían organizarse también temporadas no oficiales que, salvando el rigor moral, podrían ser regidas con un criterio estético más amplio que hiciera posible una afluencia pública que hiciese más beneficiosa para la Hacienda municipal la explotación de los servicios que constituyen el edificio de que estamos tratando. 